\title{
منهج الإسلام فى القضاء على الرق
}

\section{صفية محمد محمد سرحان}

safia.m.sarhan@gmail.com

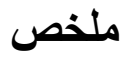

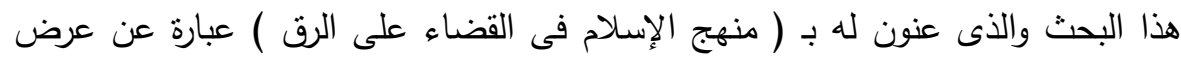
لحال الرقيق على المستوى العالمى ، ومقارنة ذللك بوضعه في الثى الثريعة الإسلامية، والتندليل

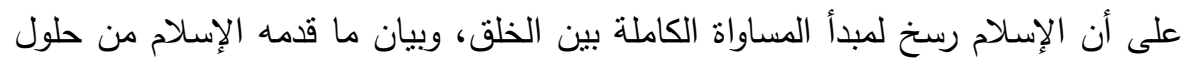

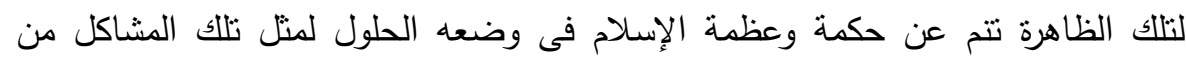

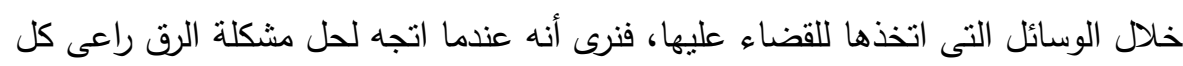

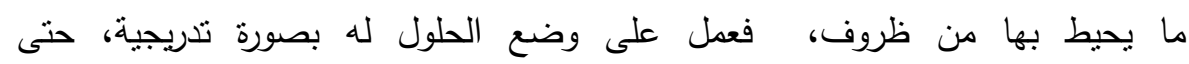

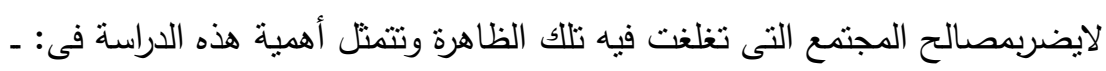

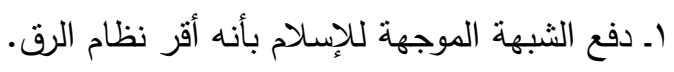

rـ بيان طريقة الإسلام المتلى في معالجة ظاهرة الرق، ومحاولة القضاء عليها. rـ إنثات أن الرقيق في الإسلام وجدوا عزا وكرامة وعاثشوا في أخوة جعلتهم مع الأحرار

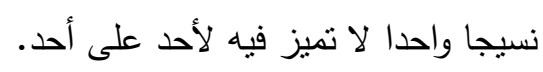
عـ بيان أن الأمم الإنسانية لم تأت بجديد فى معالجة هذه القضية بلد الإد الذى قدمه الإسلام

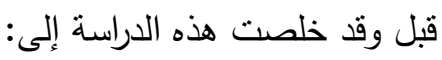

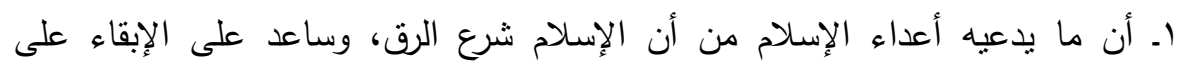

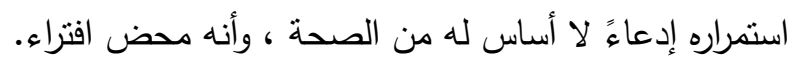

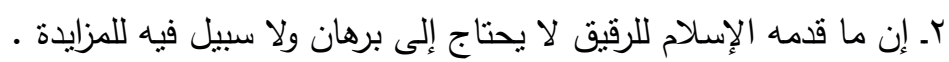

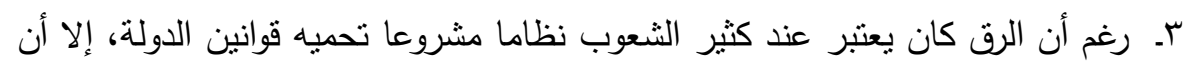
الإسلام وضع الحلول للقضاء عليه.

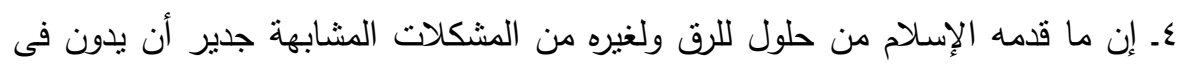

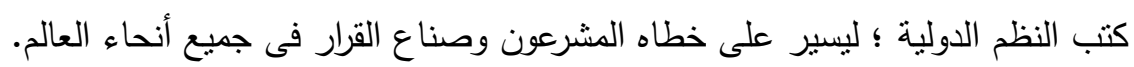

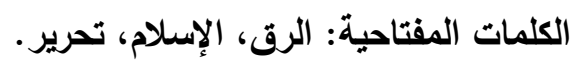
* مدرس بقسم الحديث و علومه ـ كلية الدراسات الإسلامية و العربية ـ جامعة الأزهر ــبنات

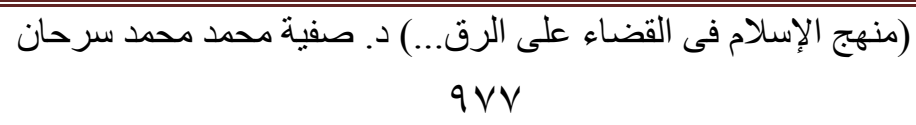




\section{المقدمة}

\section{بسم الله الرحمن الرحيم}

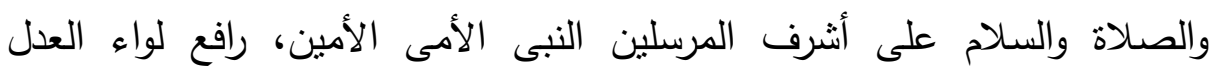

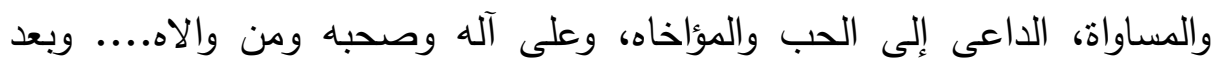
فالإسلام دعوة الحق والعدل، جاء بتعاليم غاية فى الحكمة والرقى، تهدف إلى إنارة

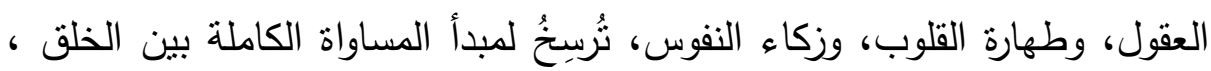
ولعل هذا المبدأ من أهم مبادئها، حيث أن الإسلام ظهر في مجنى مجنمع قبلى تسوده القسوة والظلم والاستعلاء من السادة على العبيد، فحرص الإسلام على تأصيل مبدأ

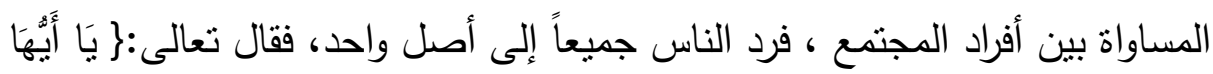

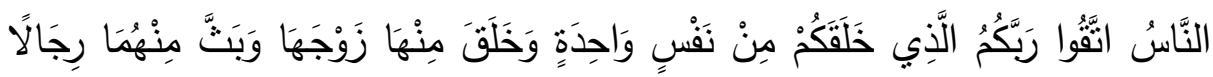

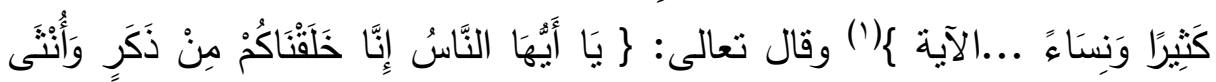

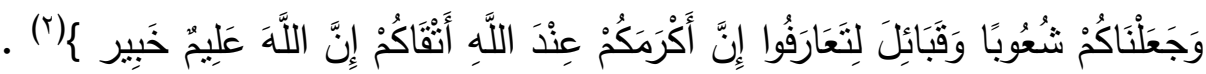

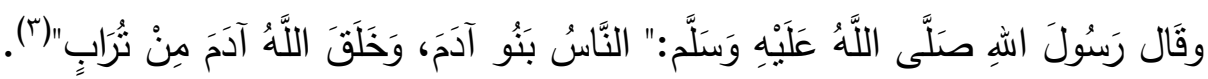

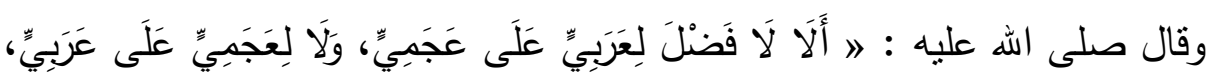

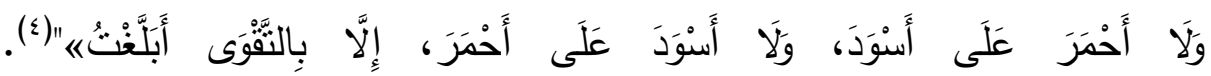
وانطلاقاً من هذا المبدأ ، فقد اتجه الإسلام إلى على ولاج ظاهرة من أخطر الظواهر فى المجتمع وهى ظاهرة الرق، إذ كيف يرضى الله للمخلوق الذى خلقه بيده وكرمه آلها

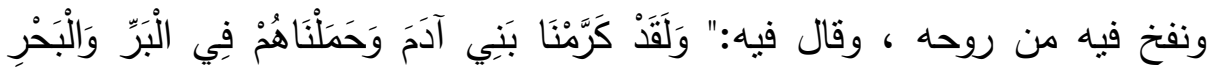

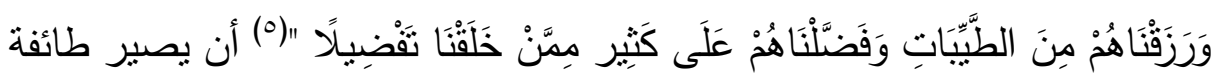
منه سلعة ثُباع وتُشترى، وتتتهك كرامتها. فعمل منذ ظهوره على إيجاد الحلول

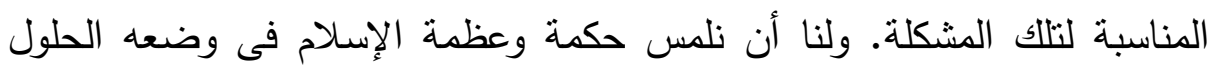
لمنل تلك المشاكل من خلال الوسائل التى اتخذها للقضاء عليها. فعندما اتجه الإسلام لحل مشكلة الرق راعى كل ما يحيط بها من ملابسات، فقد كان المجتمع

$$
\text { (منهج الإسلام فى القضاء على الرق...) د. صفية محمد محمد سرحان }
$$


فى الجزيرة العربية يعتمد على التجارة، وكان الرقيق هم العنصر الأساسى فى في

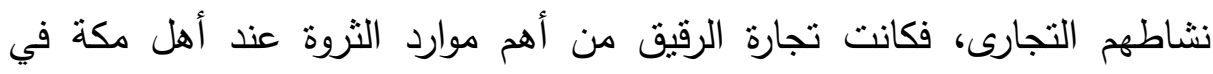

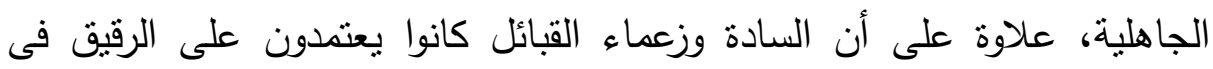
جميع شئون الحياة، فكان الرقيق يمنلون حجر الأساس فى سير الحياة الإقتصادية

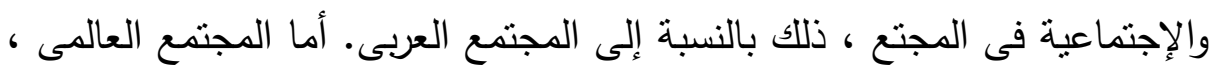
فقد كان نظام الرق يعتبر دعامة نرتكز عليها جميع نواحي الحياة، فقد كانت

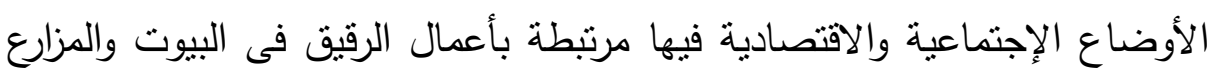

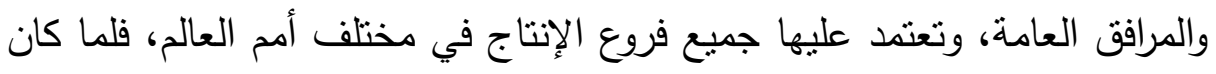
نظام الإسلام دين إصلاح لاهدم ، فقد وضع الأساس الأول لإلغاء الرق بما فيأ

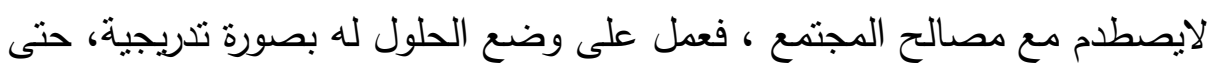

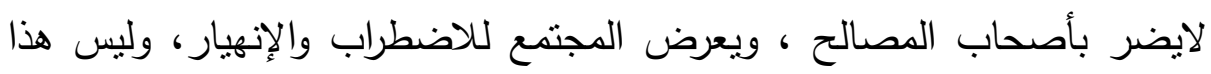

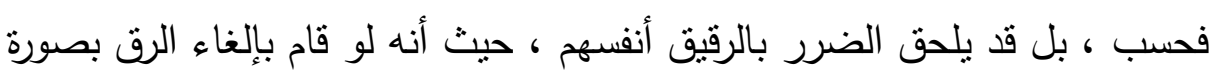

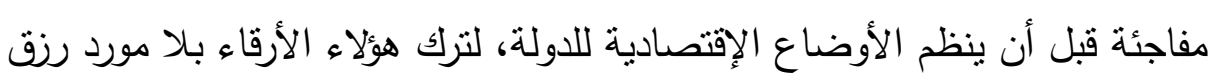
ولا كافل ولا عائل، ولا أواصر قربى تعصمهم من الفقر والسقوط الخلقي الذي يفسد

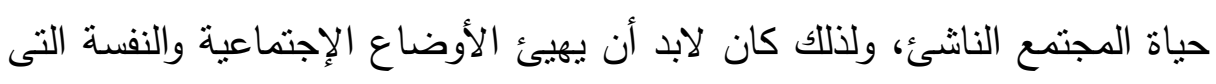
تساعدهم على التكيف مع حياة الحرية التى لم يألفوها من قبل.

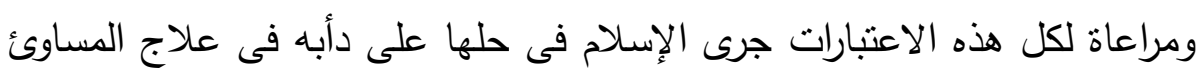

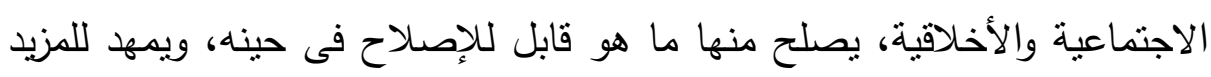

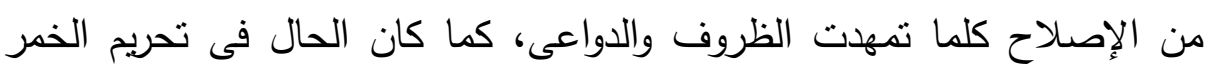
والزنا، وكالتدرج فى تشريع الجهاد وغيرهم. ورغم ما قدمه الإساحم من حلول

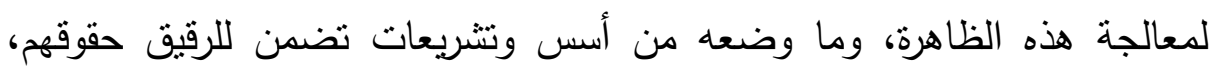
وتصون لهم كرامتهم، وتحفظ لهم إنسانيتهم إلا أنه ما زال الكثير من أعداء الإسلام يروجون الأكاذيب، فيعتبرون الرق نقطة ضعف الإسلام وبؤرة لنّ الهجوم عليه، فالإسلام عندهم أخطأ في معالجة هذه الظاهرة بل شجّع الناس على الإسترقاق الإن

(منهج الإسلام فى القضاء على الرق...) د. صفية محمد محمد سرحان 
وعلى استعباد الآخرين، ولم يصدر هذا من غير المسلمين فقط بل وأحينا يصدر

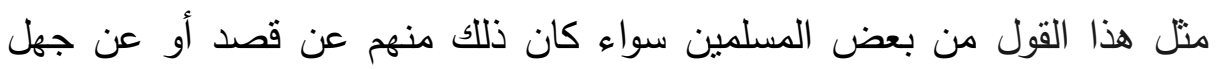
منهم وعدم دراية بشريعتهم وتعاليم دينهم، وفى السنوات القليلة الماضية كثر الكلام

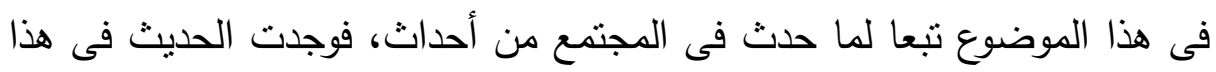

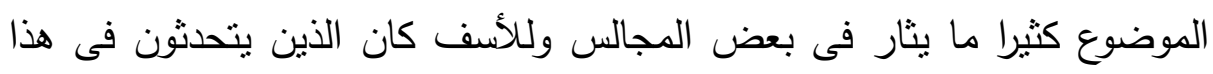

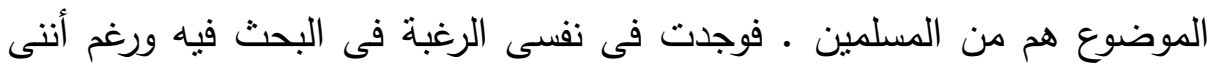

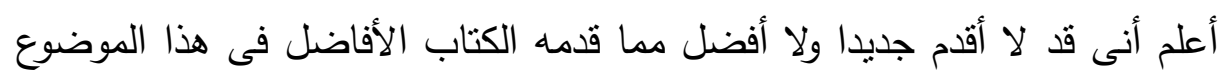

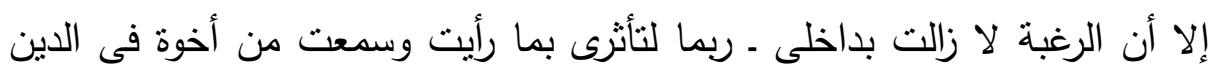

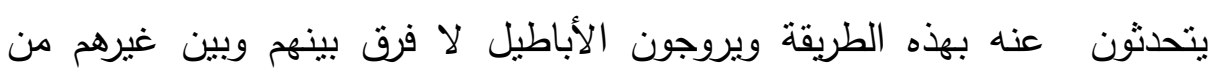
الحاقدين المغرضين، فعزمت النية على كتابة هذا البحث مستعينة باله متوكلة عليه

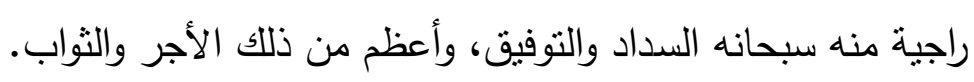
منهج البحث:

المنهج الذى انتعته فى البحث لتحقيق الخطة والانتهاء إلى النتائج هو المنهج

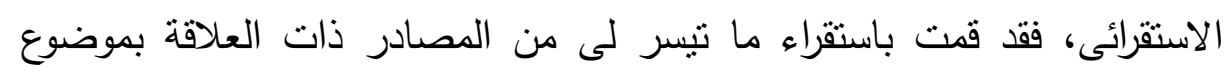

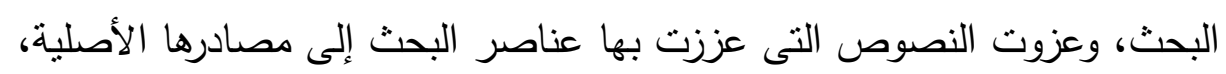

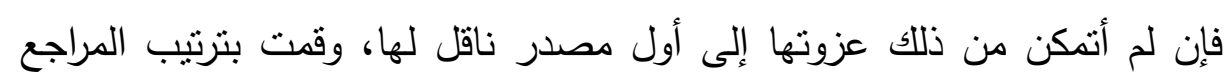
ترتيبا أبيجديا.

\section{الهذف من البحث:}

اـ دفع الثبهة الموجهة للإسلام بأنه أقر نظام الرق.

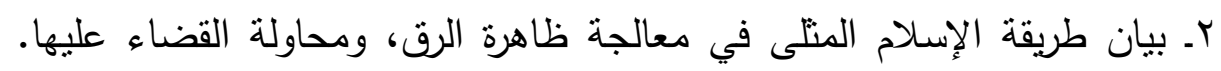

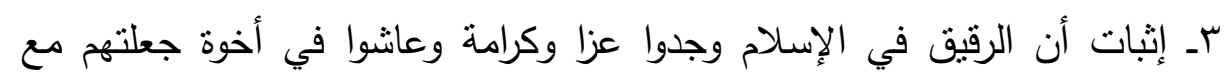

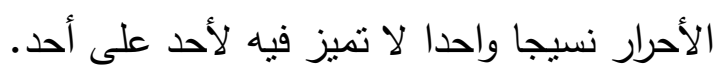

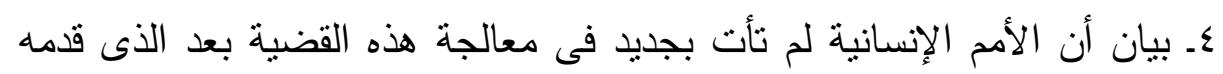

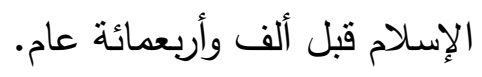

(منهج الإسلام فى القضاء على الرق...) د. صفية محمد محمد سرحان 


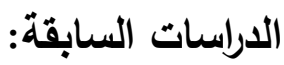

تناول الفقهاء فى مصنفاتهم قضية الرقيق، وأحكام العتق والتدبير والمكاتبة وما

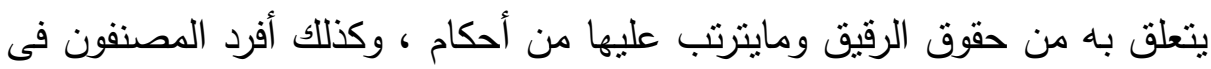

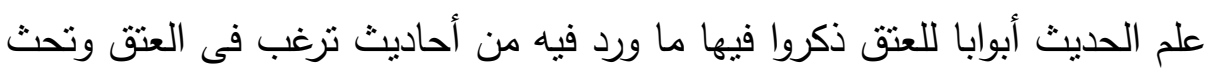

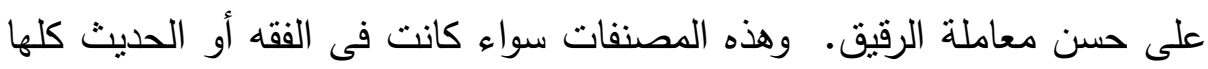

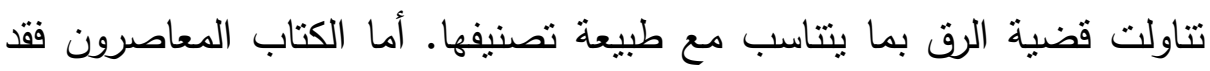
تناولوا هذه القضية من زاوية أخرى، فقد تتاولوا فيها وضع الرقيق فى ظل الإسلام

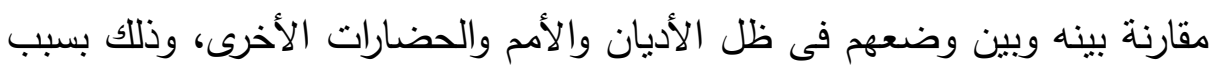

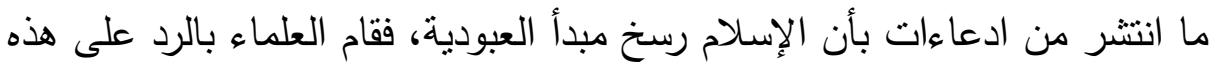

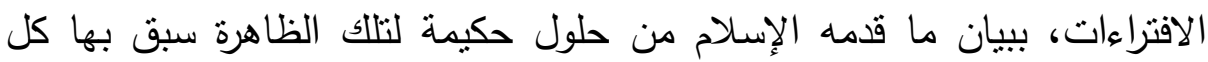

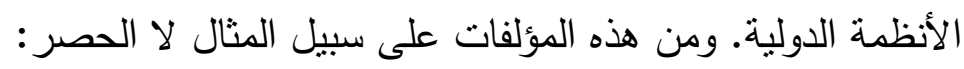

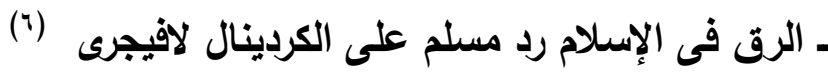
ذكر المؤلف أنه كتبه ردا على الكردينال لافيجرى والذى حضر له له خطبة فى كنيسة

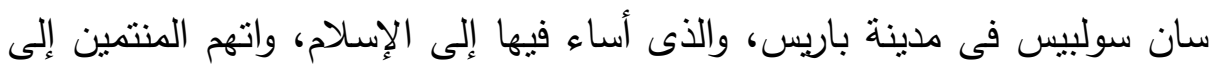

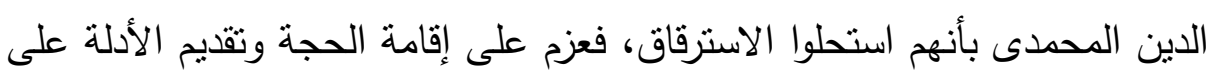

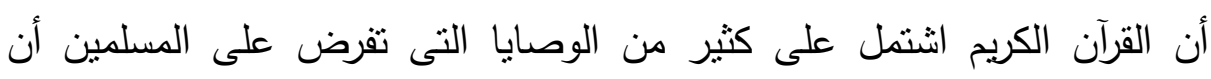
يحسنوا رعاية الرقيق، والعناية بشأنهم.

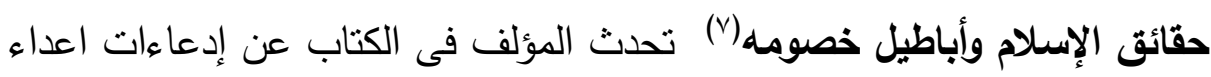
الإسلام، وقام بالرد على هذه الادعاءات وإقامة الأدلة على بطلانها، ومن بين ذلك إلكاء

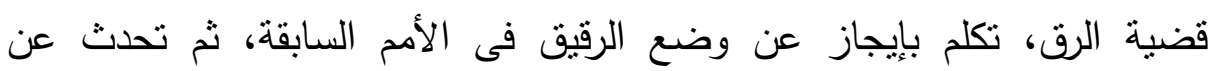

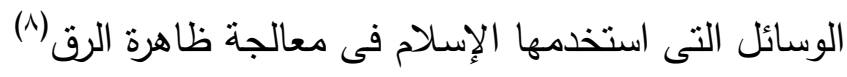

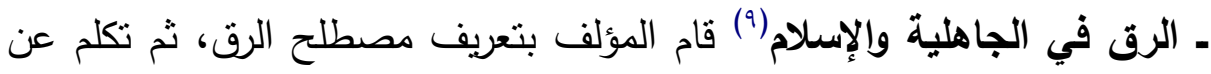

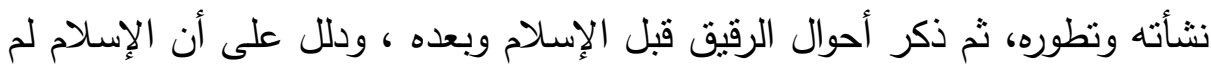

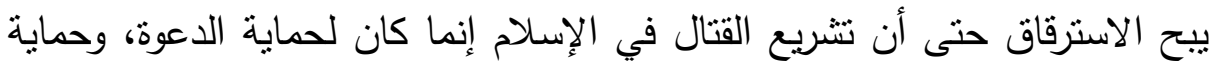

(منهج الإسلام فى القضاء على الرق...) د. صفية محمد محمد سرحان 
المؤمنين المضطهدين فهو دفاع لا هجوم ووسيلة لغاية شريفة، وإن استنقاء أسرى

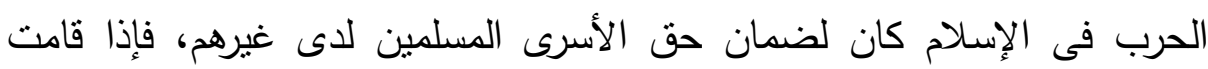

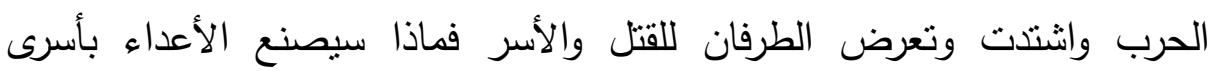
المسلمين؟ لا شك في أنهم سيأخذونهم رقيقا عندهم. فهل يطلق المسلمون الحرية لأسرى أعدائهم بينما المسلمون الأسرى هم عبيد لغيرهم يباعون ويشترون؟. لذلك نجد الإسلام جعل هذه الحالة ضرورة وقتنية تزول بزوال أسبابها ودوافعها.

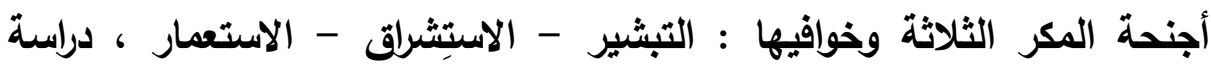

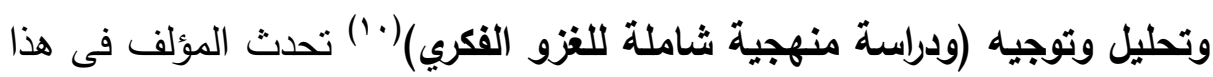

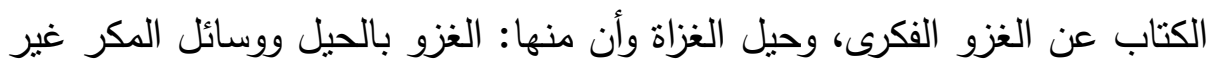
المباشرة، وذكر من أمتلنها الاستشراق والتنشير، وغيرها من وسائل الغزو ومنها

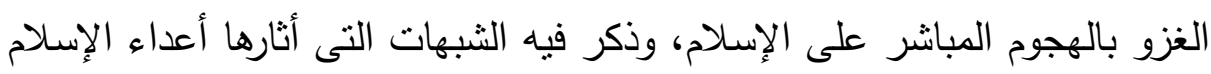
ضده وذكر من ضمنها شبهات حول الرق، فبين وسائل الاسترقاق عند الناس، وأنها كانت، ويعتمد معظمها على ظلم القوي للضعيف.

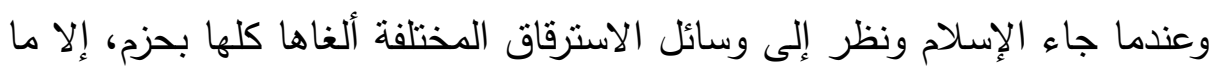

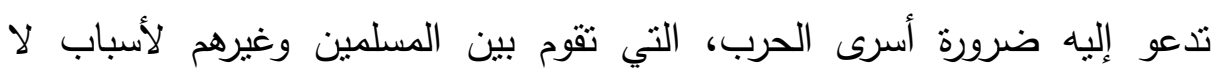
يملكون دفعها.ثم تكلم عن الوسائل التي اتخذها الإسلام لنحرير الأرقاء.

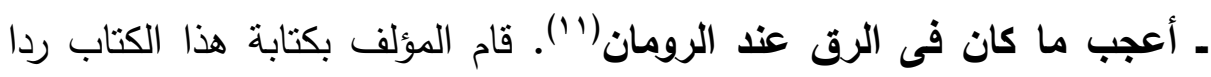

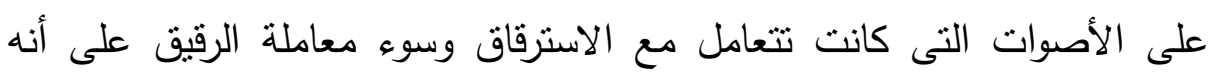

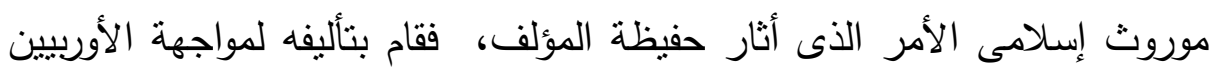

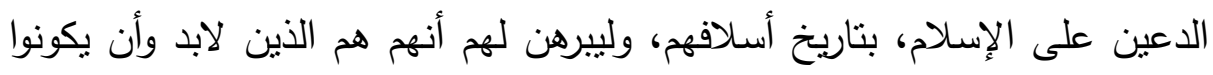

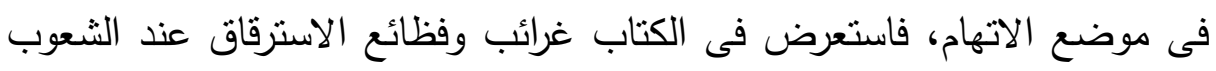

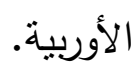

(منهج الإسلام فى القضاء على الرق...) د. صفية محمد محمد سرحان 


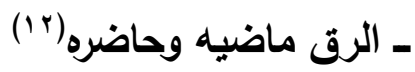

جمع مادته كما يقول في مقدمته من كتب الأدب والتاريخ والأخبار ، ومن تقارير لجنة حقوق الإنسان واللجان الخاصة المتفرعة منها ، ومن تقاربر مكافحة الرق والبوليس الدولي، أو من مشاهداته الدراسية لأحوال الرق الحديث، تكلم فيه عن نشأة الرق ومصادره، وموقف الفلسفة والديانات الأخرى من الرق، كمل تكلم عن ثورات الرقيق. ذكر أن ثوراتهم كانت نتيجة لاستعبادهم وسلب حقوقهم، وما يلاقونه

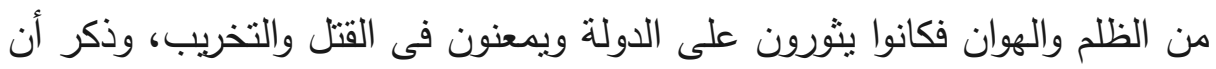
ثوراتهم كانت أكثر بكثير مما ذكره التاريخ.

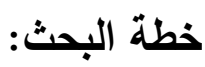

يتكون هذا البحث من: مقدمة ، وثلاثة مباحث، وخاتمة

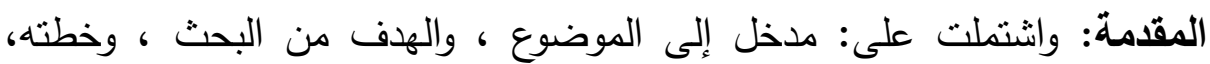
والدراسات السابقة المبحث الأول: ويشتمل على بعض العناصر منها: تعريف الرِّقّ، ونشأته، ووسائل الاسترقاق. المبحث الثانى: ويشتمل على: وضع الرق فى الأمم السابقة. المبحث الثالث: ويشتمل على: وضع الرق فى الإسلام، والحلول التى وضعها التى التها لمعالجة مشكلة الرق. الخاتمة: واشتملت على أهم نتائج البحث لهث 


\section{المبحث الأول}

\section{تعريف الرق:}

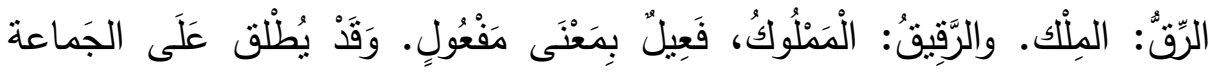

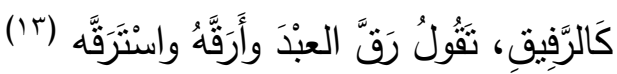
والرق في اللغة: العبودية، وسمى العبيد رقيقا، لأنهم يرقون لمالكهم، ويذلون والنئ

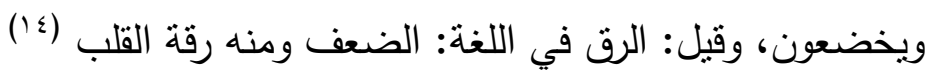

واصطلاحاً هو: حرمان الثخص من حريته الطبيعية، وصيرورته ملكا لغيره.(10) وهو نظام اجتماعي معروف بين الثعوب القديمة، واستمر قائما حتى أخريات القرن هنئه التاسع عشر، وكان بعتبر بين تلك الثعوب نظاما مشروعا تحميه قوانين الدولة. وبتحليل معنى الرق في عرف الناس قديماً وحديثاً يتبين لنا أنه يرجع إلى عدة ينّان عناصر وهذه العناصر التي يرجع إليها معنى الرقّ على اختلاف درجاته ومستوياته

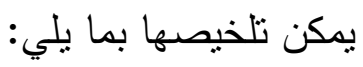
أولاً: سلب حرية التملك وسلب حرية العمل الذي قد يفضي إلى التملك. ثانياً: تكليف الرقيق أن يبذل ما يستطيع من جهد، مقابل منحه ما يحتاج إليه من مأكل ومشرب ومأوى وضروريّات العيش الأخرى التى لا بدّ منها.

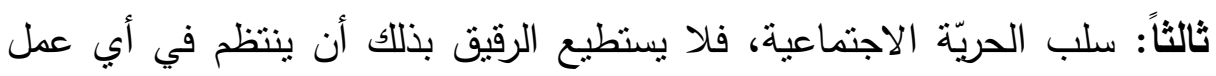
جماعي مهما شرفت أهدافه. رابعاً: سلب الحرية السياسية، فلا يستطيع الرقيق بذلك أن يدلي برأي سياسي يتتاول الأوضاع السياسية للمجتمع الذي هو فيه. خامساً: سلب الحرية الدينية والاعتقادية، ولقد كان الأرقاء يعذّبون عذاباً شديداً إذا اتبعوا ديناً غير دين أسيادهم. سادساً: الحجر على الرقيق وتكليفه أن يظل عند سيده، يخدمه ، فإذا أراد الهجرة

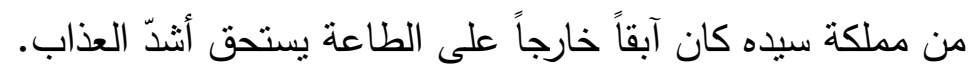

(منهج الإسلام فى القضاء على الرق...) د. صفية محمد محمد سرحان 
سابعاً: اعتبار جسد الرقيق وروحه مستباحين لسيّده، بعذّبه كما يهوى، ويقتله إذا

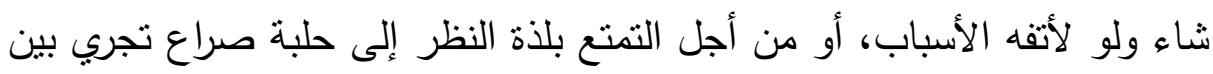
الأرقاء وتتنهي بقتل بعضهم أو بعذاب دون التقاء التنل، ليسعد السادة بآلام العبيد. ثامناً: تسخير الأرقاء في قتال أعداء مالكيهم.

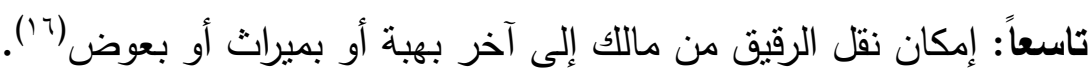

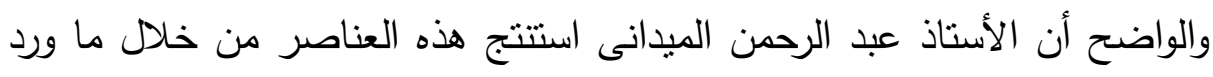

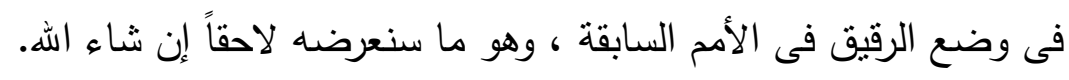
نشأته:

ولقد عُرف الرق من قديم الزمان، وكانت الحرب بادئ الأمر عاملا هاما من عوامل

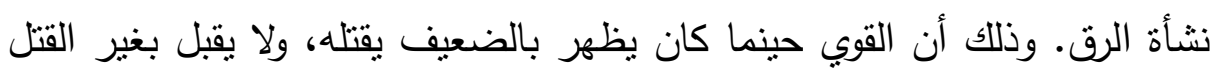

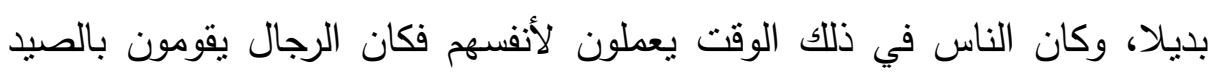

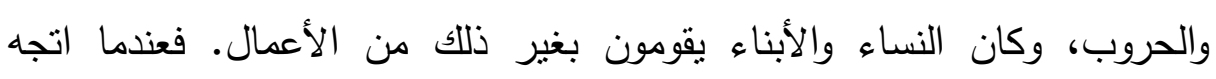

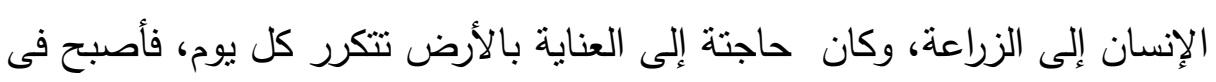

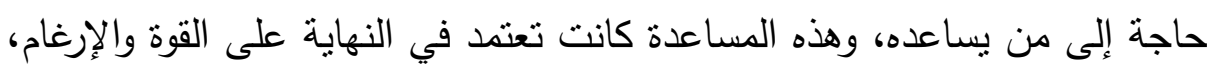

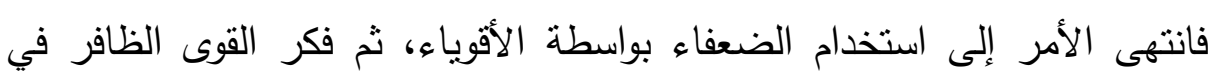

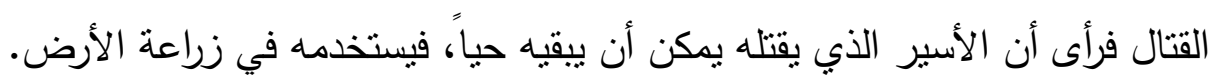

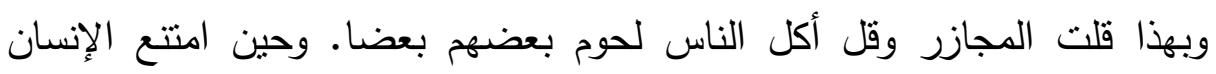

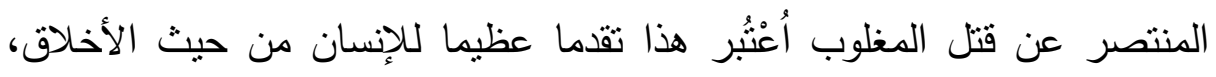

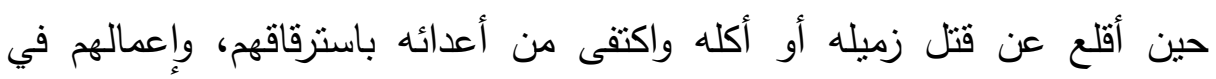

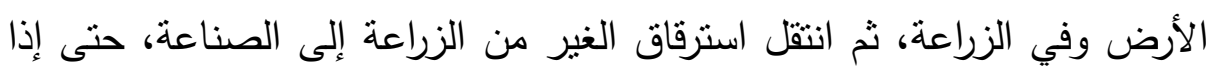

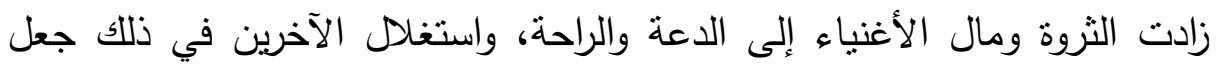

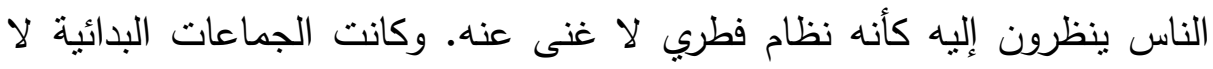
ترى فارقا بين الحر والعبد، ولا تجد رقا ولا طبقات، ولا تدرك من الفوارق بين التان

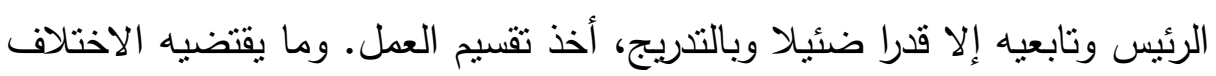

$$
\text { (منهج الإسلام فى القضاء على الرق...) د. صفية محمد محمد سرحان }
$$


بين الناس يستبدل شيئا فنشيئا المساواة بقليل من التحكم الذي زاد على مرور الأيام، ثم لما ازدادت الآلات والصناعات تعقدا، عمل ذللك على إخضاع الضعيف لمشيئة القوى، وكلما ظهر سلاح جديد في أيدي الأقوياء زاد من سلطانهم على الضعفاء واستغلالهم إياهم. ثم عمل نظام التوريث على اتساع الهوة بأن أضاف إلى الى الامنياز

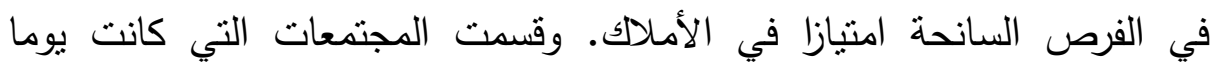
متجانسة إلى عدد لا يحصى من طبقات وأوساط، وأحس الأغنباء والفقراء بغناهم أو فقرهم إحساسا يؤدى إلى التشاحن، وأخذت حرب الطبقات تسرب خلال التاريخ حتى انتهت إلى وجود طبقة من الناس تُشتخدم وكأنها آلة تتحرك بغير إرادتها

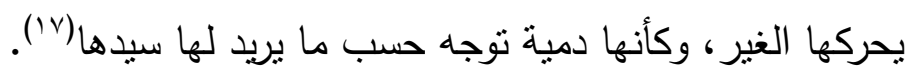

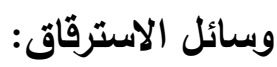
عرف الناس قديماً نظام الاسترقاق، وكانت وسائله لديهم منتوعة ، ويعتمد معظمها على ظلم القوي للضعيف. فكان من وسائله: الأسر، الذي ينجم عن الغزو وعن الحروب، سواء أكانت حروباً بين شعوب مختلفة، أو حروباً بين قبائل من شعب واحد، أبي: سواء أكانت حروباً خارجية أو حروباً أهلية، وكان مصير الأسير فيها القتل أو الاسترقاق أو الفداء.

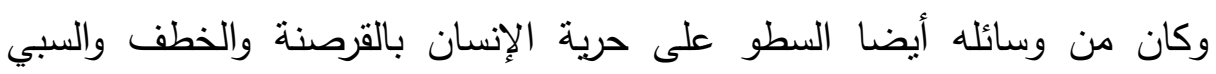
والسرقة والتقاط اللقطاء ونحو ذللك. ومن الذين كانوا ضحايا هذا النوع فاسترقوا

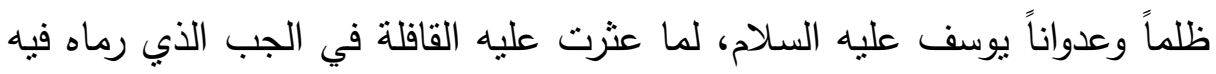

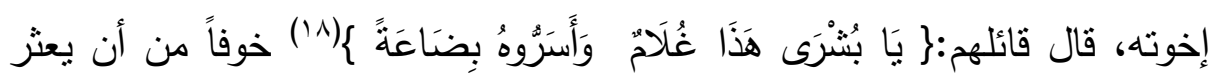

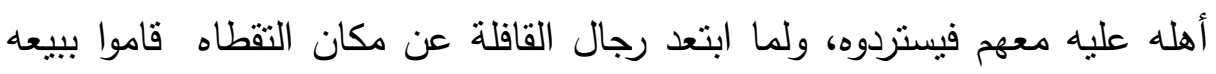

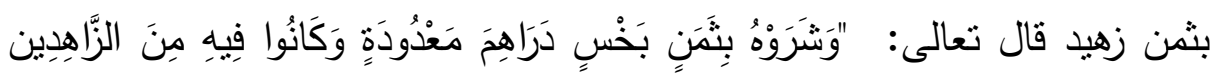

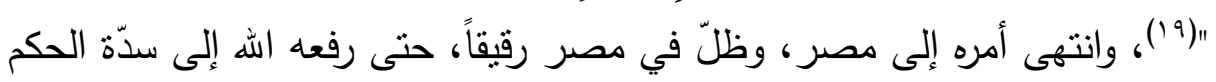
في قصته المشهورة المذكورة في القرآن.

(منهج الإسلام فى القضاء على الرق...) د. صفية محمد محمد سرحان 
ومن الذين كانوا ضحايا هذا النوع من الاسترقاق زيد بن حارثة، إذ كان صغيراً بعثه

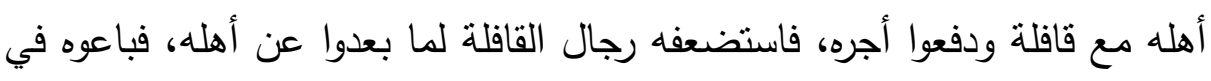
مكة رقيقاً، وظل كذلك حتى أعتقه رسول الهه ولكنه بعد حريته اختار أن يظل خادماً لرسول الله على أن يذهب مع أهله الذين عثروا عليه فيما بعد فطلبوه.

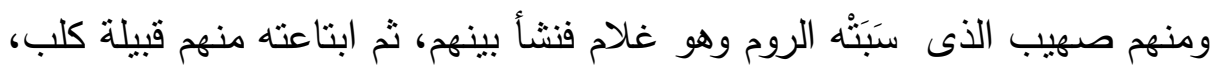
فقدمت به مكة، فاشتراه عبد الله بن جدعان، وقد كان من المستضعفين المعذبين في الله.

ومنهم زنوج الولايات المتحدة الأمريكية الذين سباهم تجار القراصنة، من سواحل

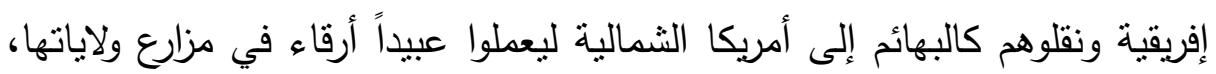
ضمن أسوأ الظروف الحياتية ذلاً وتعذيباً وإجهاداً بأعمال شاقة. وكان من وسائل الاسترقاق ارتكاب بعض الجرائم الكبيرة، كالقتل والسرقة والزنى، إذ باعطان

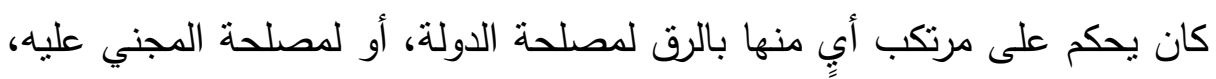
أو لمصلحة أهل المجني عليه. وكان من وسائله عجز المدين عن وفاء الدين الذي عليه، إذ كان يضرب عليه الرق ويملك لدائنه.

وكان بعض الناس بييعون أبناءهم أرقاء، وبييعون بناتهم رقيقات بحكم سلطتهم عليهم، ليأخذوا أثمانهم، وكان يحدث كثير من هذا في الطبقات الفقيرة، وكانت الأنظمة العامة لاى كثير من أمم الأرض تسمح بذلك وتبيحه، وتعطي نتائجه صفة ولثة الحق المحمي بالسلطان العام. وكان إذا اثتد الفقر أو الخوف ببعض الناس تتازلوا عن حريتهم لمن يكفيهم ويؤويهم ويحميهم. وكان من وسائل الاسترقاق تناسل الأرقاء، فكان ولد الجارية الرقيقة يولد رقيقاً ولو

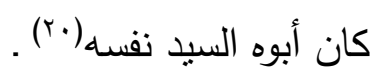

(منهج الإسلام فى القضاء على الرق...) د. صفية محمد محمد سرحان 


\section{المبحث الثانى \\ وضع الرق فى الأمم السابقة:}

1ـ الرق عند القدماء المصريين:

كان الرق من دعائم المجتمع عند قدماء المصريين، وكانوا يتخذون الإماء للخدمة،

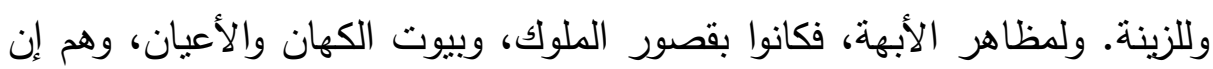
كانوا يسيئون معاملة رقيق الخدمة، بحيث يعتبرونهم كآلة صماء، فإنّ رقيق الزينة على العكس. فقد كانوا يلقون معاملة حسنة كما بدل على ذلك قول العزيز لامرأته

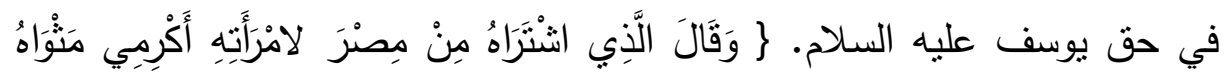

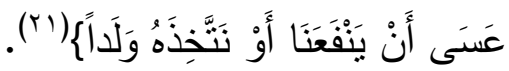
ولقد أباح العبرانيون الرق، وذكر في التوراة في مواضع ، وكان الرق عندهم نوعين:

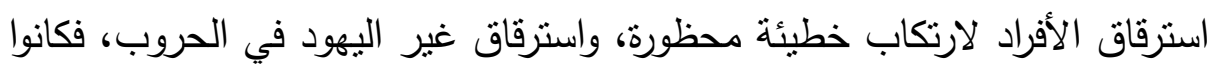

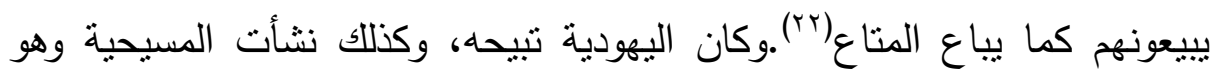
مباح فلم تحرمه، ولم تتظر إلى تحريمه فى المستقبل، وأمر بولس مدعي الرسالة

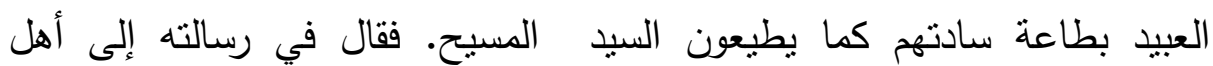
أفسس(Tr(T) " أيها العبيد! أطيعوا سادتكم حسب الجسد، بخوف ورعدة في بساطة قلوبكم كما للمسيح، ولا بخدمة العين كمن يرضى الناس، بل كعبيد المسيح عاملين مشيئة الله من القلب خادمين بنية صالحة كما للرب ليس للناس عالمين، أنه مهما عمل واحد من الخير فذلك يناله من الرب عبدا كان أم حرا". وأوصى مدعى لئه

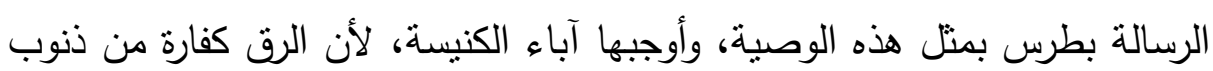

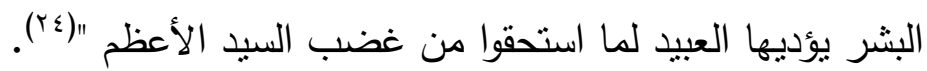
ونص في الإنجيل على أن الناس كلهم إخوان، ولكنه لم بنص على على منع الاسترقاق،

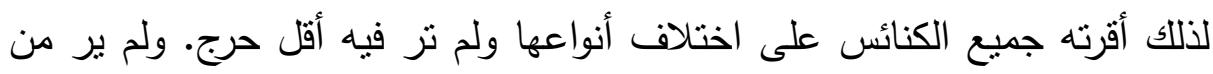
جاء من باباوات النصارى ولا قديسيهم حرجا من إقرار الرق. وقال القسيس

$$
\text { (منهج الإسلام فى القضاء على الرق...) د. صفية محمد محمد سرحان }
$$


المشهور: بوسويت الفرنسي: "إن من حق المحارب المنتصر قتل المقهور، فان

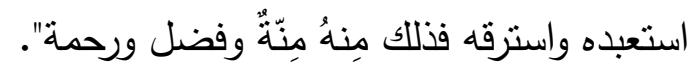

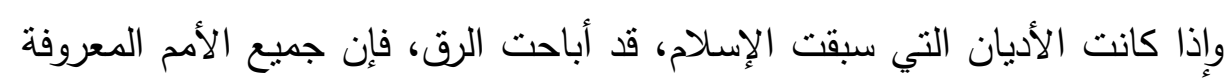

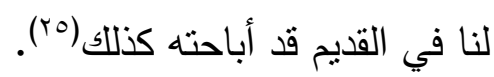

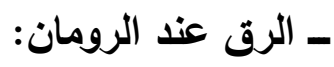
كان مَنّل الرقيق عند الرومان كمنل البهيمة، مسلوب الحقوق الإنسانية كلها، فكانوا يسخرونه في الأعمال الثاقة، وفي الحرب، وفي إرضاء أهوائهم الفاجرة الدنيئة،

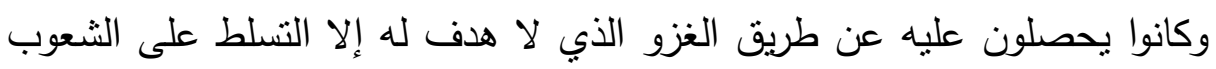

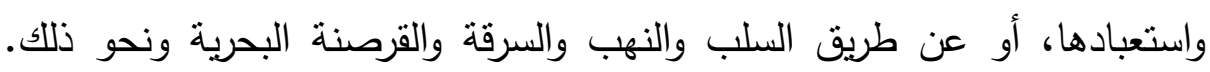

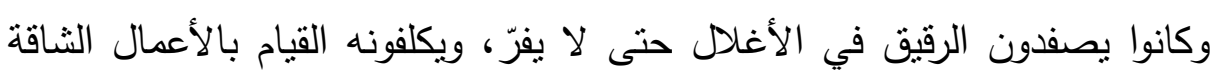

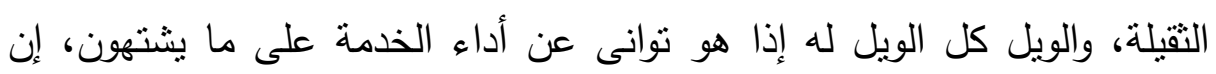
توانيه يعرّضه لإنزال العذاب الثديد به. أما مساكن الرقيق عندهم فقد كان شبيهة بمغارات السجون القاتمة الكريهة، أو لوانئ زرائب الحيوانات، أما الأسياد فلهم القصور الفخمة وكل وسائل الرفاهية والنعيم.

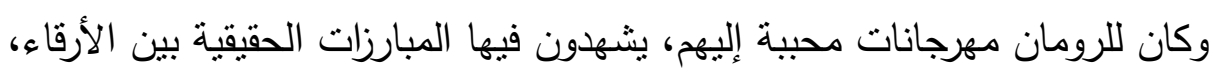

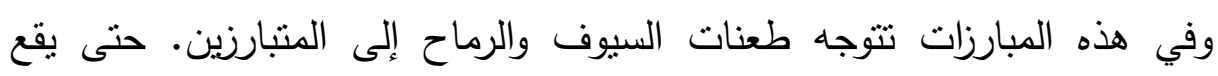

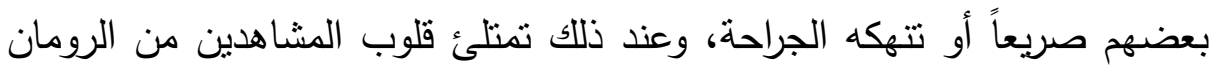
مسرّة واغتباطاً بآلام العبيد (بَ).

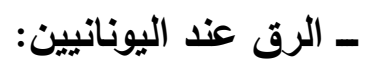

أما اليونان فقد كانت المذاهب الفلسفية لديهم تصوغ المبررات الفكرية لنظام الرق.

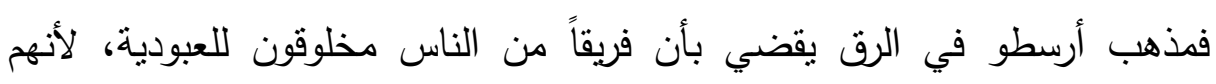

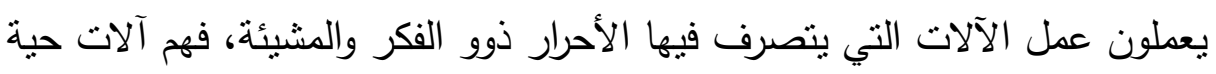
تلحق في عملها بالآلات الجامدة. وأفلاطون أستاذ أرسطو يقرر في جمهوريته الفاضلة أن العبيد ليسوا مواطنين، وهو يجبرهم على الطاعة والخضوع للأحرا. وقد

$$
\text { (منهج الإسلام فى القضاء على الرق...) د. صفية محمد محمد سرحان }
$$


شرعت الحضارة اليونانية نظام الرق العام- وهو لمصلحة الدولة - ونظام الرق

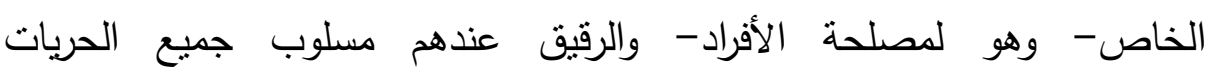
الإنسانية(Y)

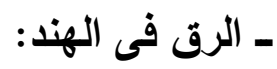
وفي الهند قسمت الثرائع البرهمية(^^) القديمة الأشخاص الملزمين بالخدمة إلى الى قسمين وهما: الخادمين والأرقاء، فالأعمال الطاهرة من خصائص الخادمين، والأعمال النجسة

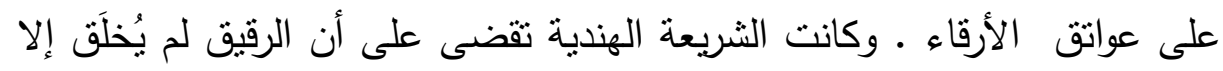

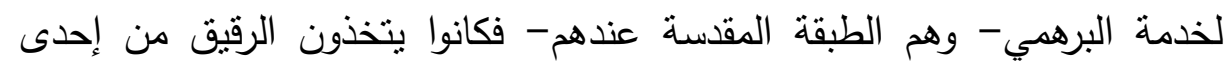
طبقات المجتمع التي تعتبر صفة العبودية لازمة لها حتى لو تخل السيد عن عبده

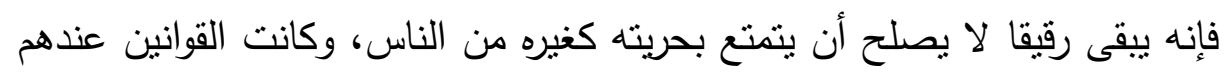

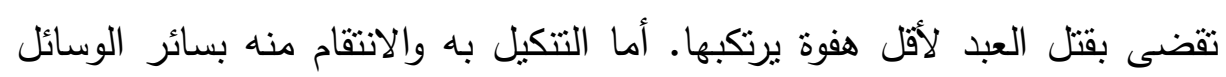

$$
\text { ـ الوحثية فحدث ولا حرج(ب9). }
$$

وكان الرق عند الفرس بدولتهم العظيمة التي امتدت في حدود آسيا المعروفة فى وقتها، ينقسم إلى: الأرقاء الرعاة، والأرقاء المختصون بحاجات الزئه الزينة والثروة

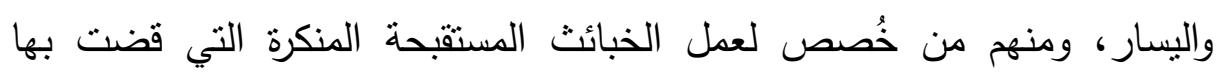

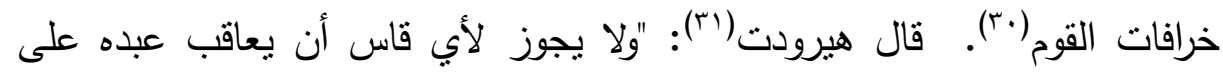

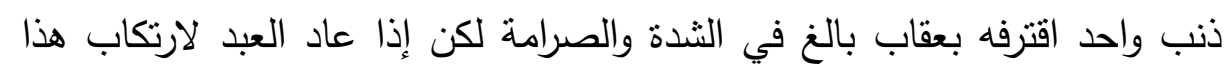

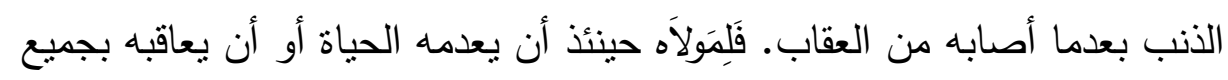
ما بتصور من أنواع العذاب" (rr) .

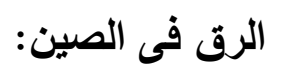

كان الصينيون يجلبون الرقيق من الخارج بواسطة الحروب والأسلاب، أو يأخذونهم

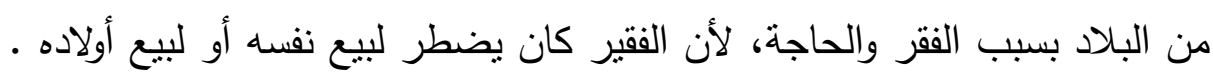

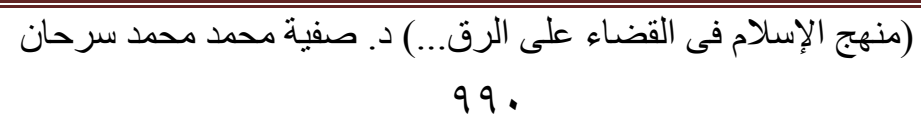


ولعل الصين كانت في القديم من أكثر الدول اعتدَالا في معاملة رقيقها، فكان

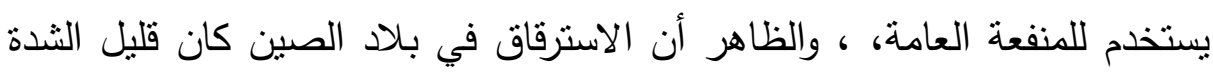

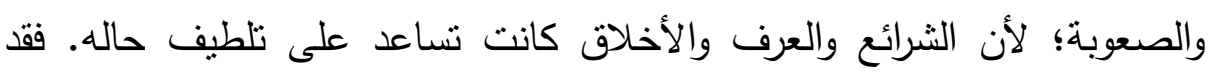
أصدر الإمبراطور كوانجون (وهو الذى كان عائثاً بعد المسيح بخمسة وثثلاثثن عاماً) أمرين اثثين بوقاية حياة الرقيق وشخصه ضمَّنَها عبارات تشف عن عن كمال

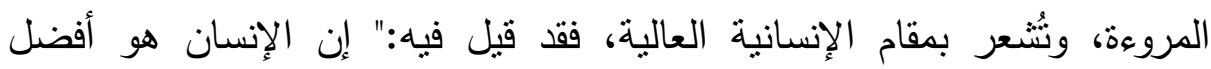

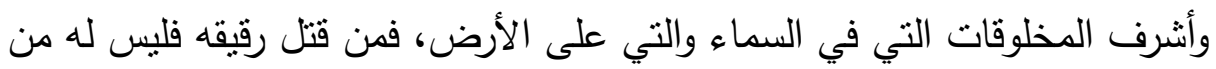

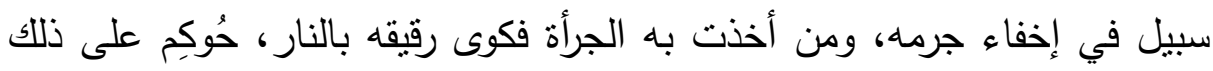
بمقتضى الشريعة، ومن كواه سيده بالنار دخل في عدد الوطنيين الأحرار ، ولقد كان

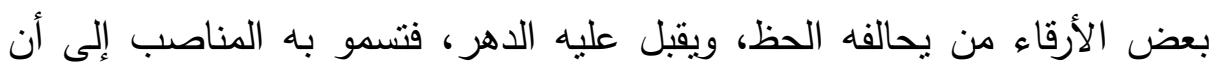
يكون موضع ثقة من مولاه، بل ويجد فى بعض المكاسب طريقة ينال بها حريته

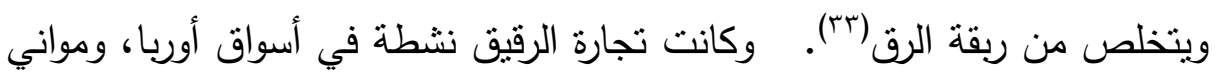
جنوة والبندقية وليفورن في إيطاليا تعج بالمراكب التي تحمل أبناء السود من الجنسين المخطوفين من إفريقيا، وبعض دول آسيا، وكان أكثر القائمين على هذه

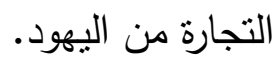

ولم يكن الحال في أمريكا بأقل منه في الدنيا القديمة، فلقد كانت بواخرها تتنقل بين شاطئ أفريقية وبين أمريكا حاملة الألوف من أهل إفريقية للاتجار، وللزراعة، باتهات

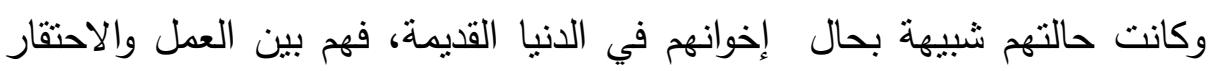
والمهانة، فكان على غاية الثدة والقسوة، وكانت القوانين تصرح بأن للسيد كل حق إنق

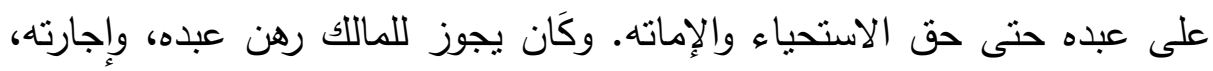

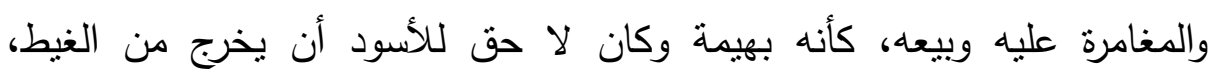
ويطوف بشوارع المدن إلا بتصريح قانوني، ولكن إذا اتقق واجتمع في شارع واحدٍ

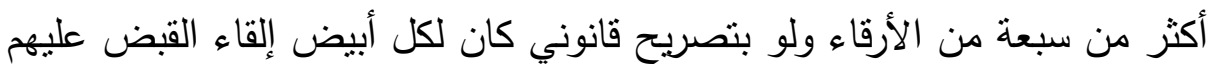

(منهج الإسلام فى القضاء على الرق...) د. صفية محمد محمد سرحان 
وجلدهم، وقد صرح قانونهم على أن ليس للعبد روح ولا عقل وأن حياتهم محصورة في أذرعهم (זّ).

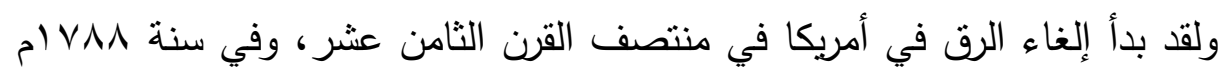

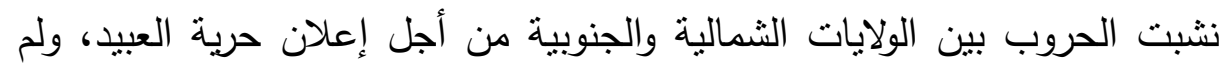

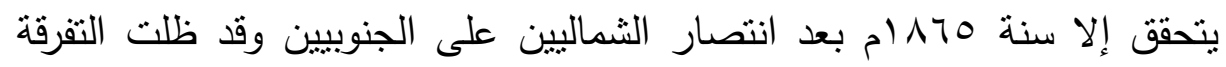
العنصرية شائعة سنوات عديدة، ولم يكن من المككن أن يذخل العبيد في الأماكن

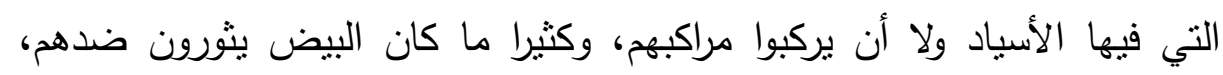

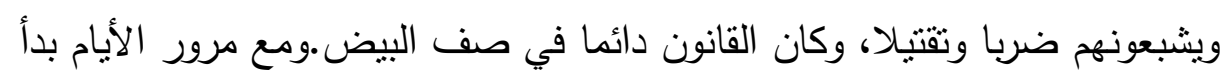

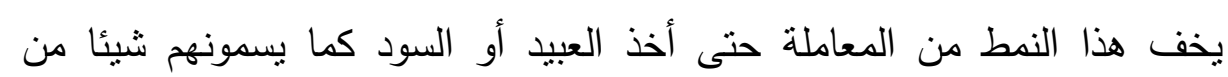
المشاركة في الحياة العامة. ولقد بقي الرق على شرعيته عند غير المسلمين إلى أن قررت الثثرة الفرنسية إلغاءه

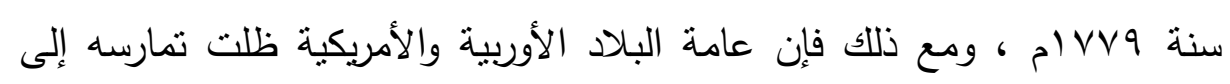

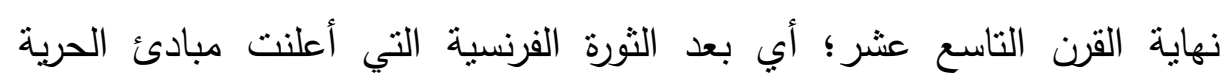
والمساواة بين الناس بما يزيد على قرن كامل من الزمن (ro).

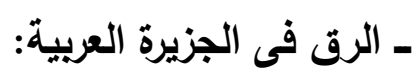
وكان الرق في الجزيرة العربية لا يختلف كثيرا عما كان عليه في الأمم الأخرى.

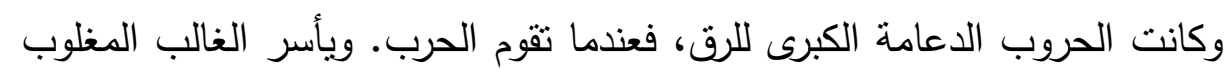

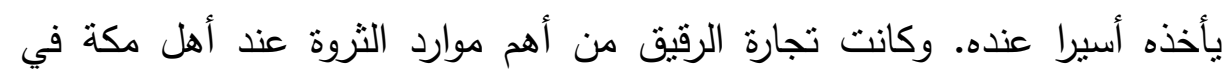

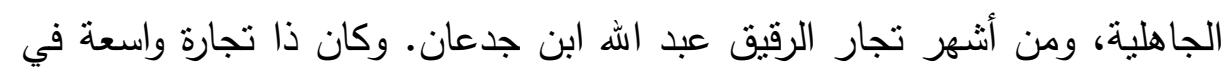

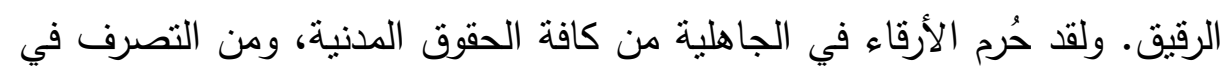

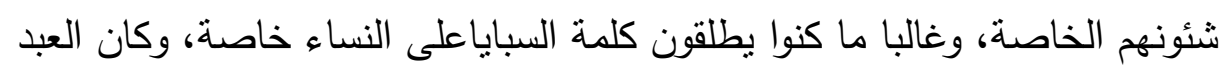

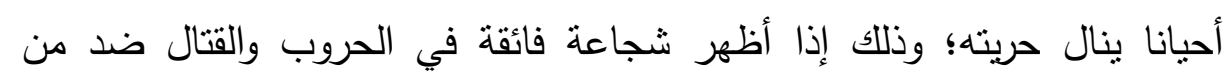
يعتدي على سيده وعلى قبيلته، وأيضا فقد يكون الإخلاص الثنديد سببا في التروب الفيال

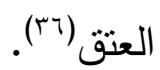

(منهج الإسلام فى القضاء على الرق...) د. صفية محمد محمد سرحان 


\section{المبحث الثالث \\ وضع الرقيق فى الإسلام}

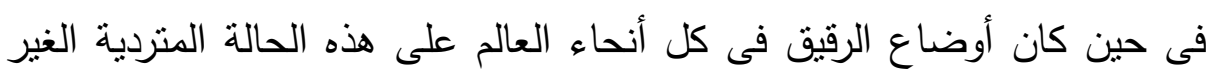

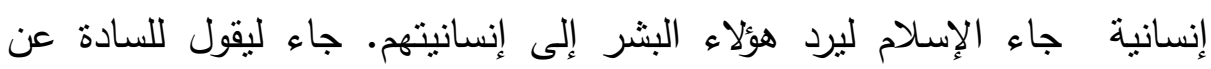

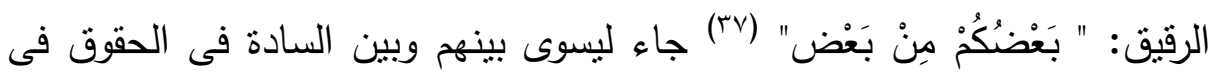

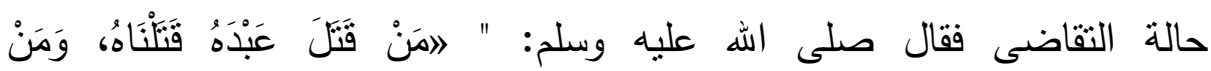

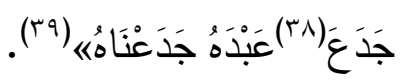
جاء ليقرر وحدة الأصل والمنشأ والمصير:" " النَّاسُ بَنْوُ آَدَ، وَخَلَقَ اللَّهُ آدَمَ مِنْ

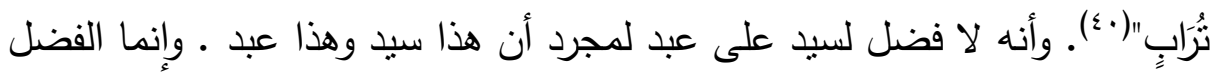

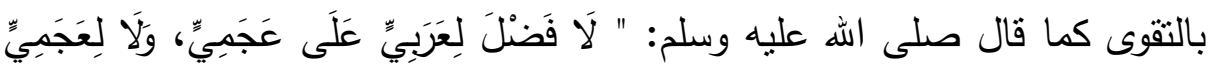

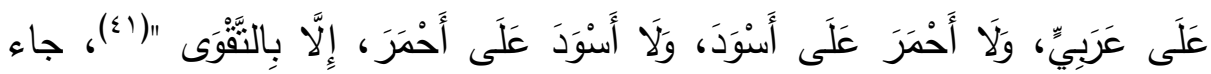

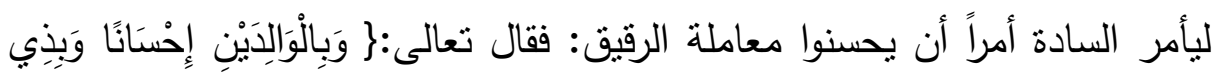

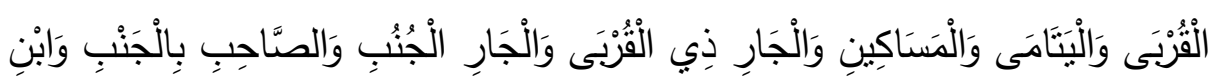

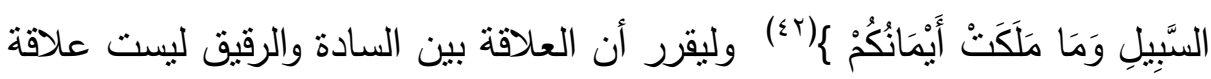

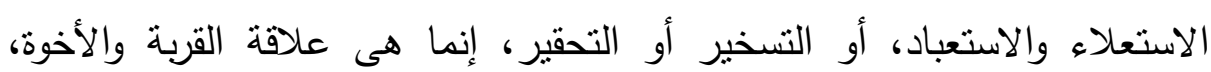

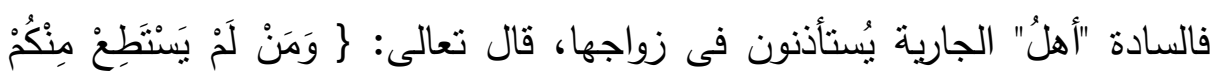

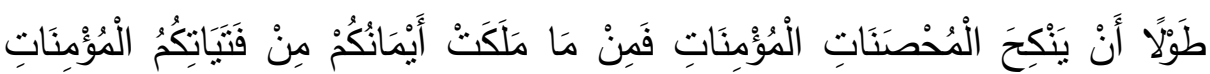

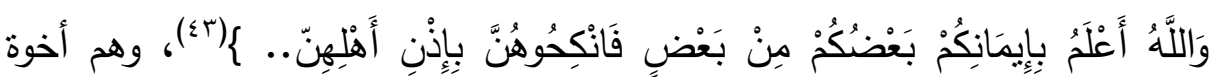

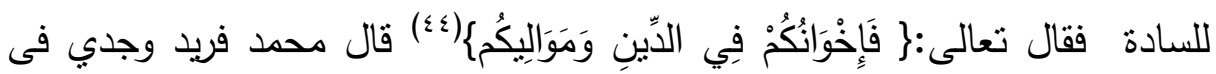

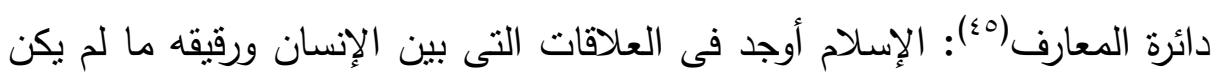

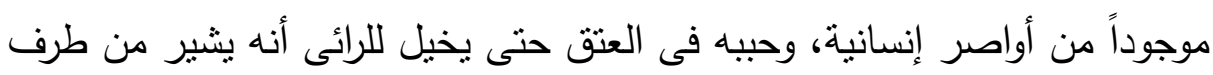

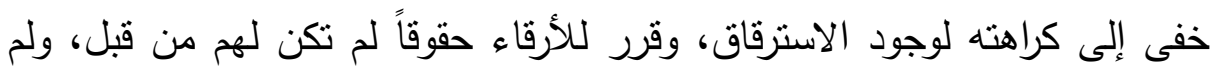

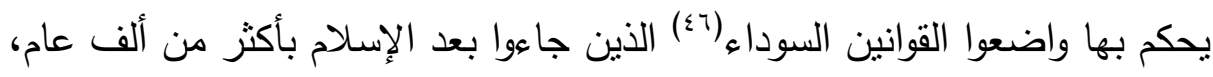
وقد علم ذللك مؤلفوا الأفرنجة، ونقل عن العلامة غوستاف لبون فى كتابه( تمدن

(منهج الإسلام فى القضاء على الرق...) د. صفية محمد محمد سرحان 
العرب ) قوله:" إن لفظ الرق إذا ذكر أمام الأوربى الذى اعتاد ثناوة الروايات

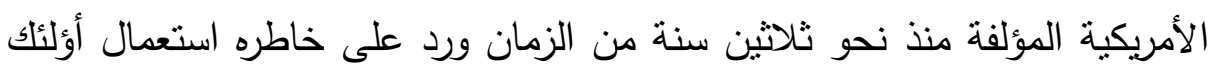

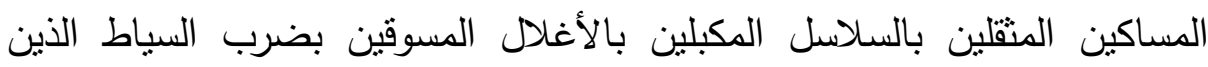

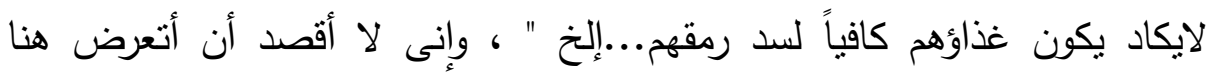

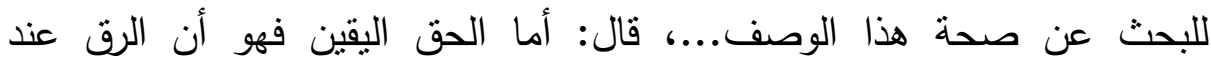

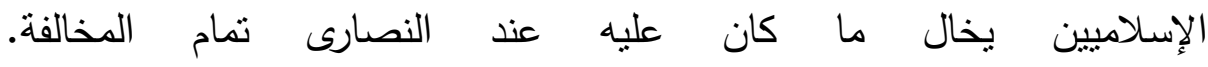
وقال محمد فريد بعد أن ذكر نماذج من وصية الإنسلام بالأرقاء: هذا شأن تعاليخ

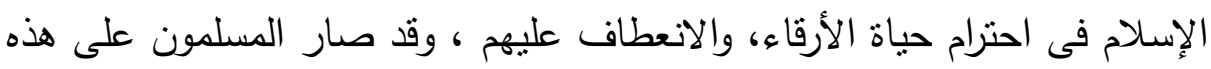

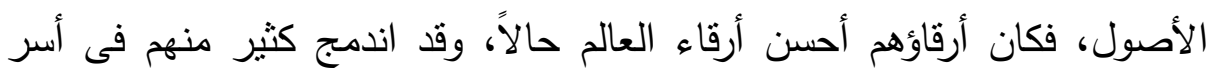

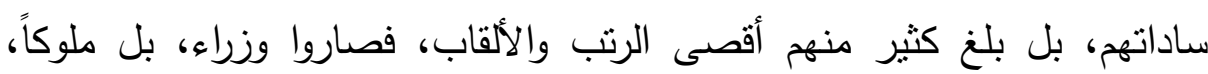

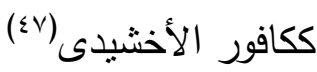

\section{الحلول التى وضعها الإسلام لمعالجة مشكلة الرق:}

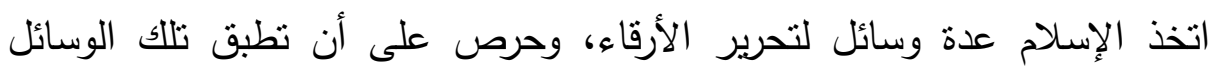

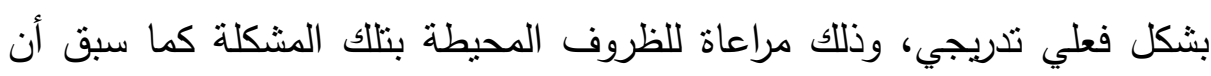

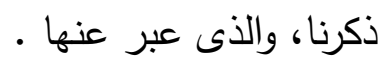
الأستاذ د. علي عبد الواحد وافي قال: "ظهر الإسلام في عصر كان نظام الرق فيه

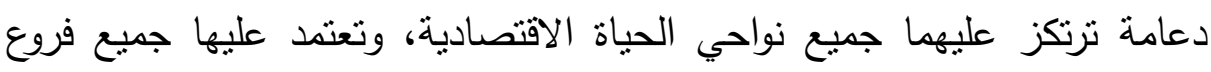

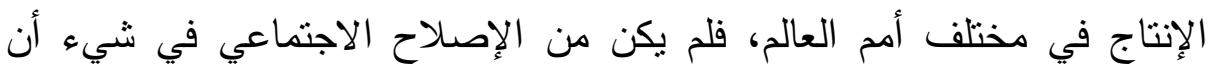

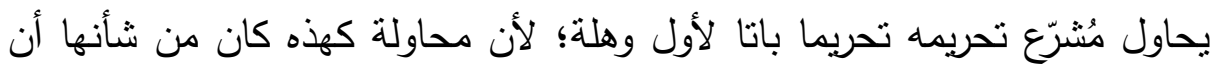

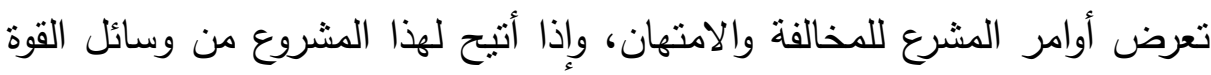

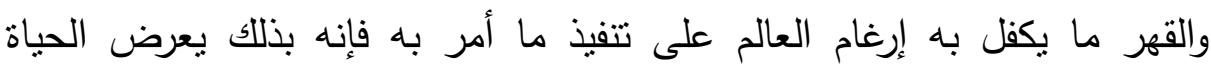

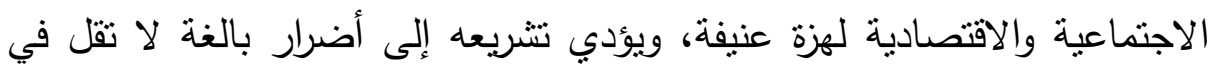

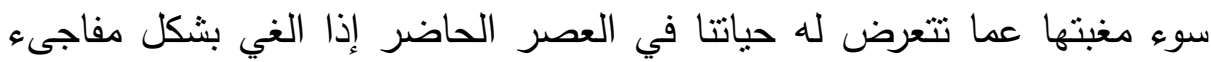

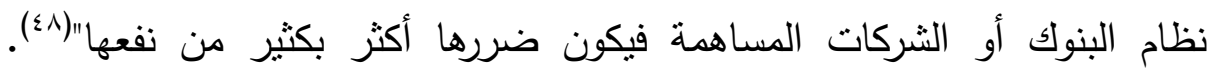

(منهج الإسلام فى القضاء على الرق...) د. صفية محمد محمد سرحان 
ولأجل الوصول إلى الحل الأمتل لتلك المشكلة، فقد سلك الإسلام فى طريق حل هذه المشكلة عدة مسالك منها:

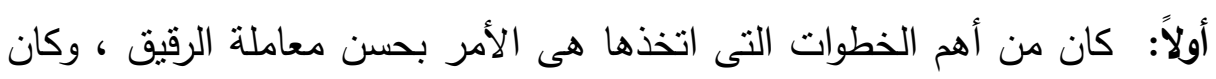

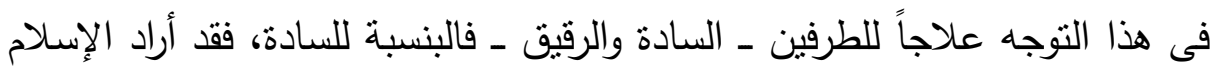

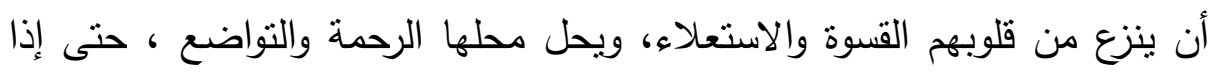

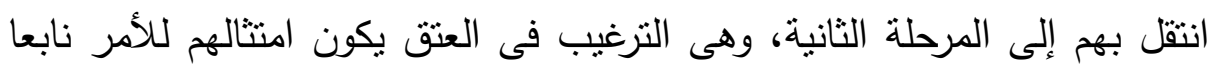

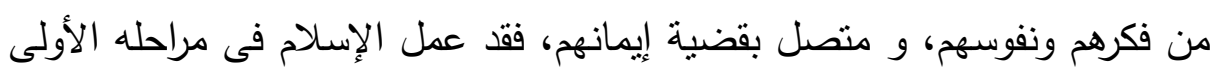
على تغيير الطبيعة البشرية، وجطلها ترتقى برقى الدين الذى تنتمى إليه.

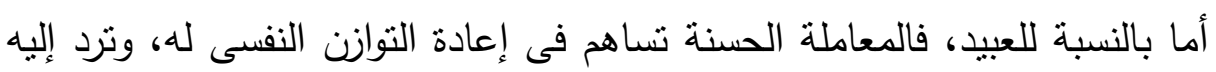

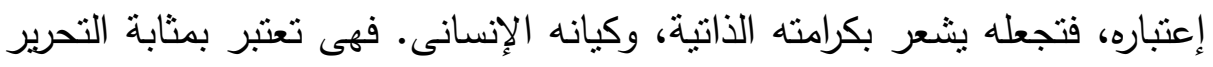

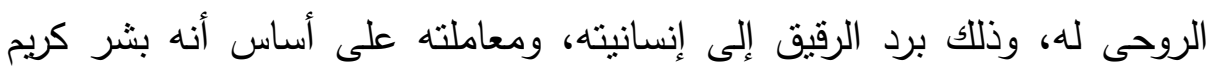

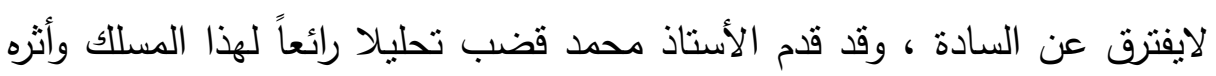
الإيجابى فى نفس العبد، قال: إن الحرية لا تمنح بل تؤخذ، وتحربر الرقيق الإنيق بإصدار

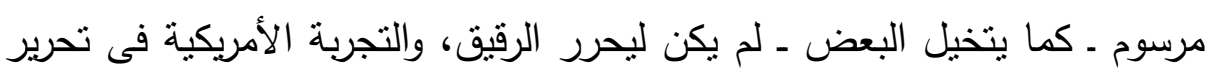

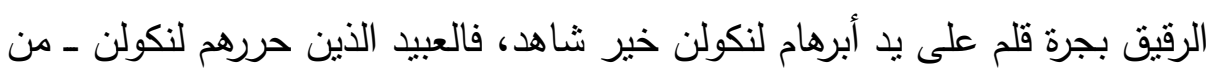

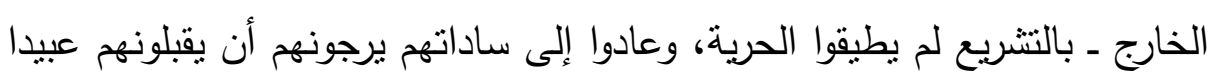

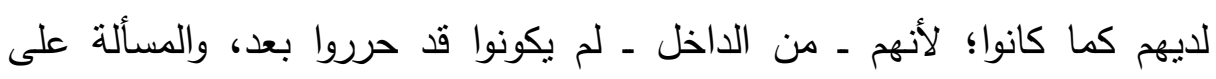

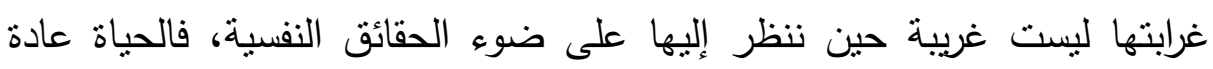

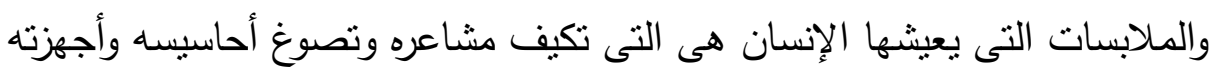

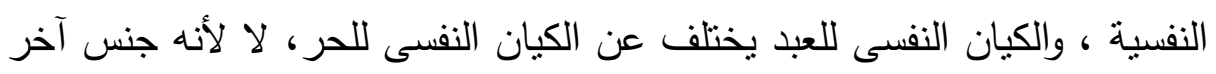

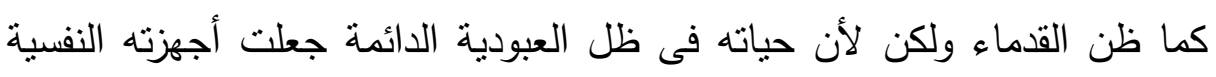

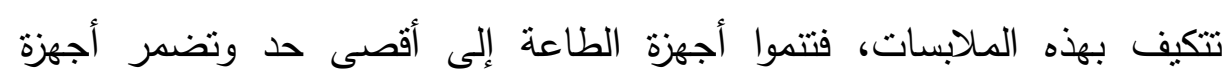

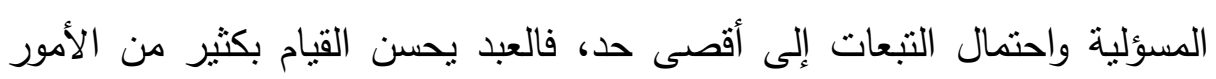

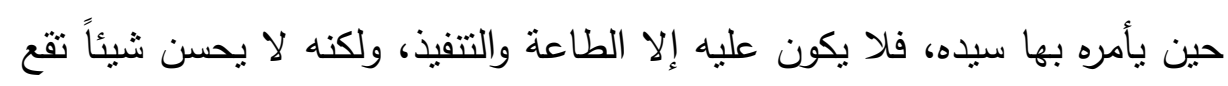

$$
\text { (منهج الإسلام فى القضاء على الرق...) د. صفية محمد محمد سرحان }
$$


مسؤليته على نفسه، ولو كان أبسط الأثياء، لا لأن جسمه لا يطيق العمل به، ولا

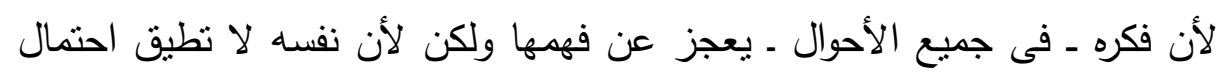

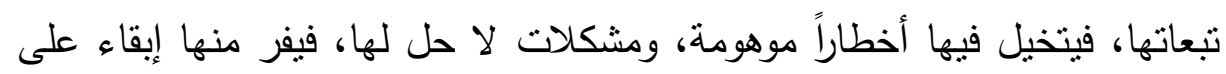
نفسه من الأخطار (9)؛ (9).

\section{ومن مظاهر حسن معاملة الرقيق التى أمر بها الإسلام:}

اــ نهى أن يُنادى الرقيق بما يدل على تحقيره واستعباده، إذ قال صلى اله اله عليه

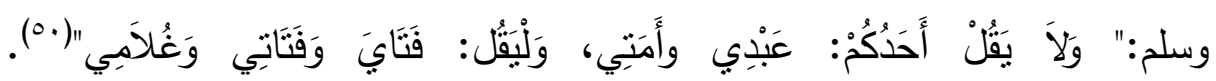

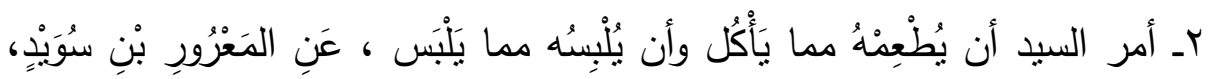

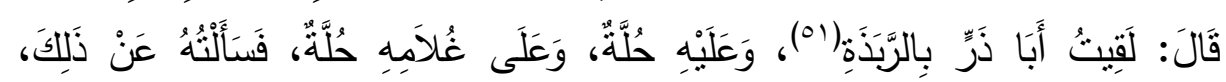

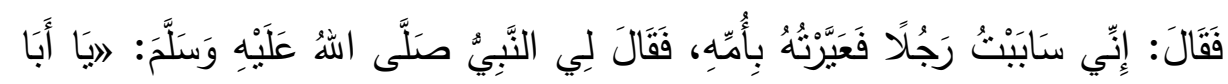

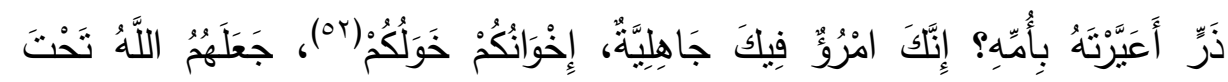

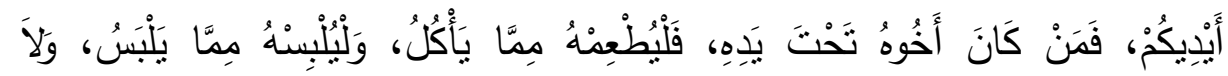

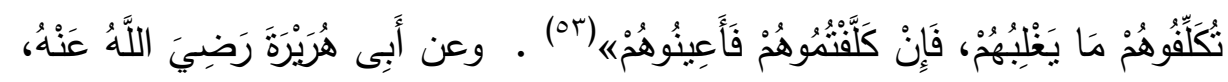

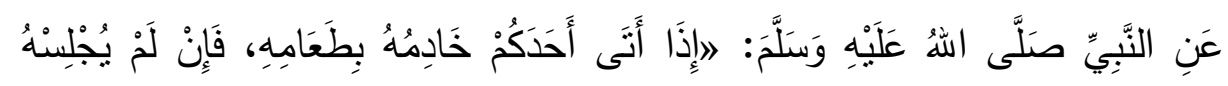

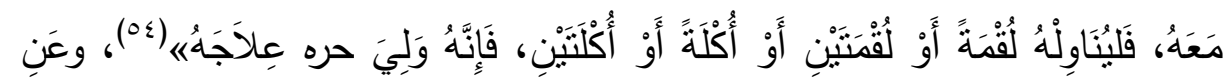

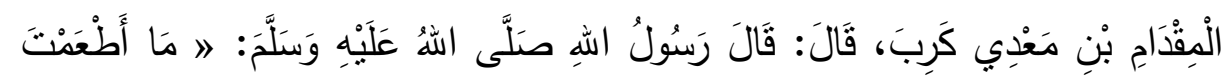

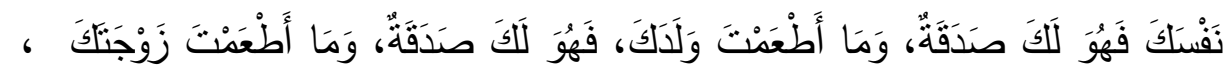

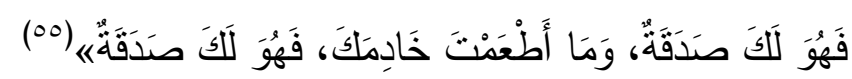

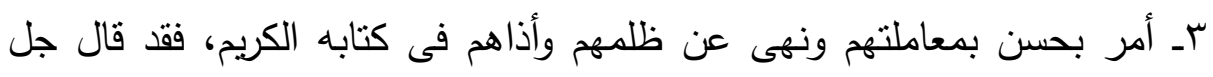

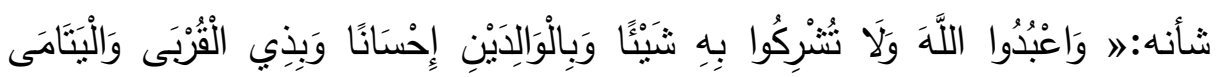

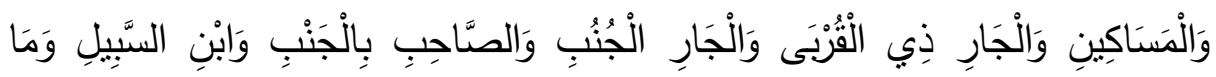

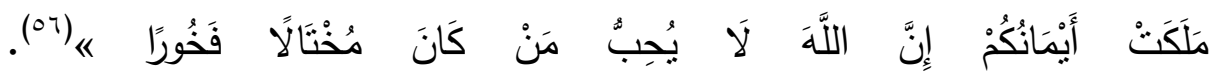

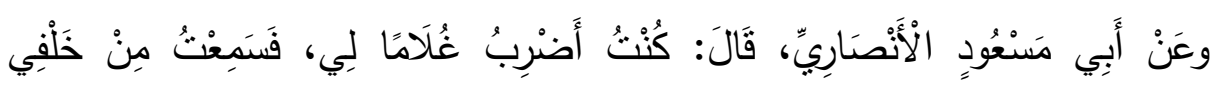

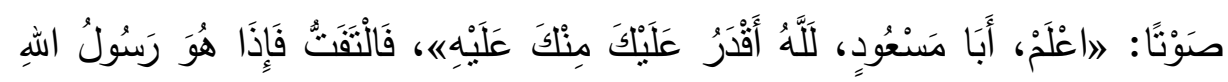

(منهج الإسلام فى القضاء على الرق...) د. صفية محمد محمد سرحان 


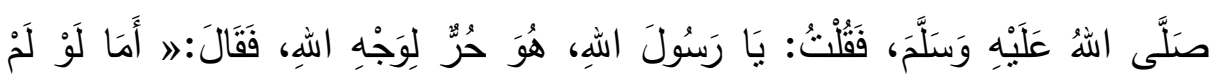

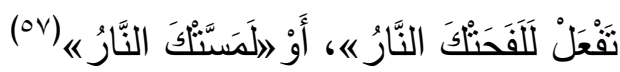

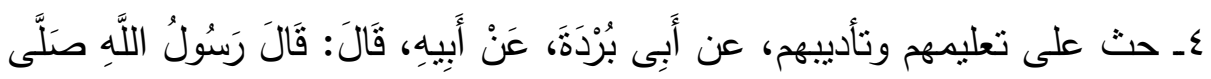

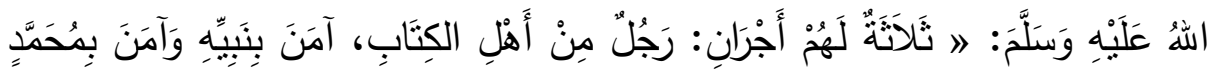

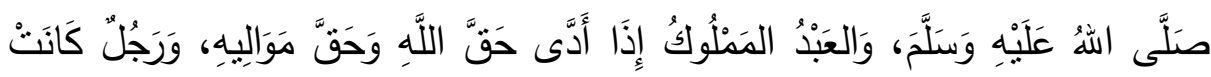

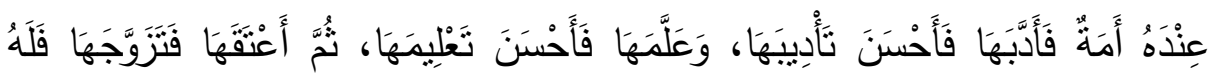

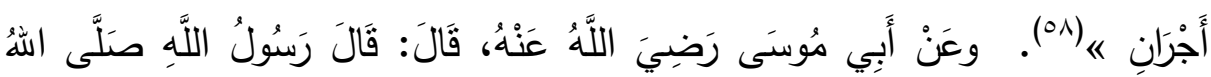

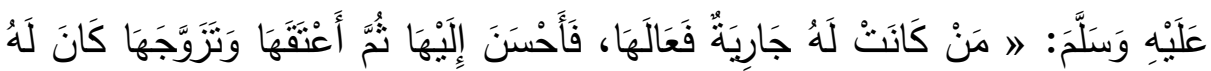

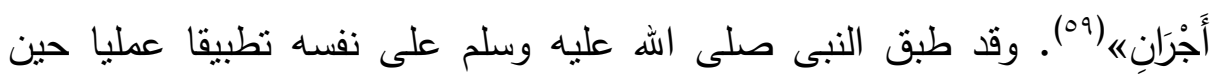

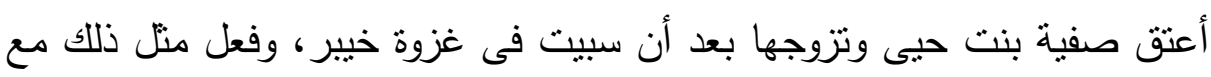
جوريرية بنت الحارث بعد أن سبيت فى غزوة بنى المصطلق.

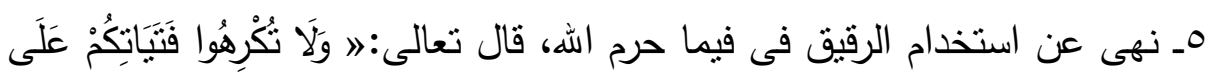

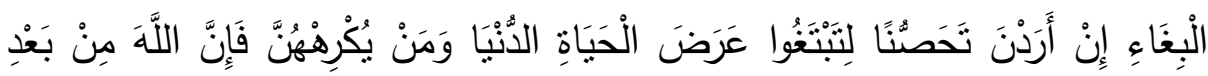

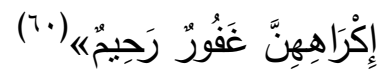
وورد فى سبب نزول هذه الآية ما رواه جابر رضى الله عنه، قال: جاءت جارية الكاية

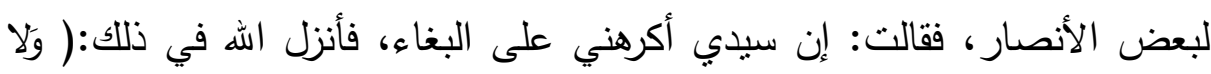

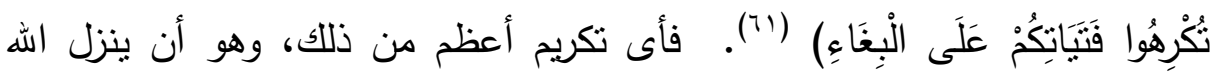

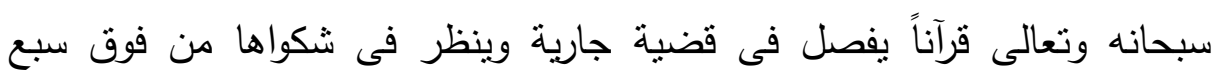

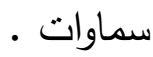
Tـ ومن مظاهر الإحسان أن القرآن الكريم استعمل عبارة " الفنتات " كناية عن

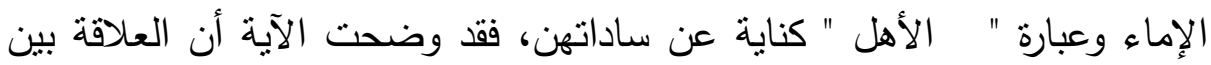

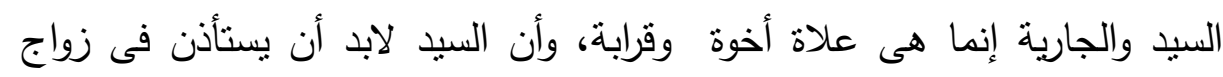

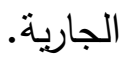

(منهج الإسلام فى القضاء على الرق...) د. صفية محمد محمد سرحان 
والذى ينظر إلى هذه الأمور يدرك أن الإسلام قد وصل فى حسن معاملة الرقيق،

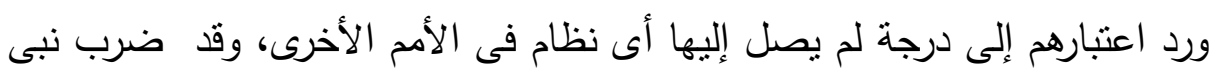

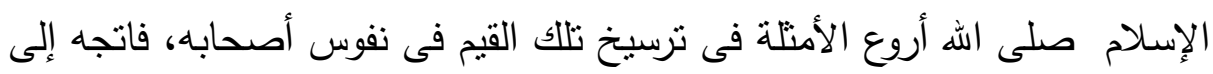
التطبيق العملى؛ ليكون أمراً واقعا أكثر تأثيرا فى النفوس، فمن تلكئ الأمثلة : أنه صلى الهه عليه وسلم آخى بين بعض الموالى والأحرار من سادات العرب،

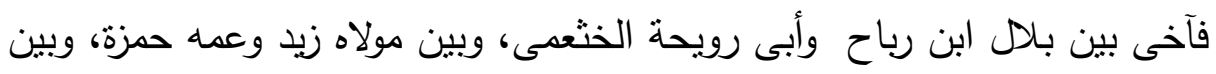

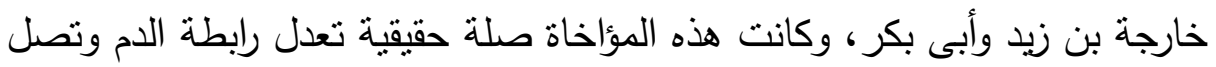

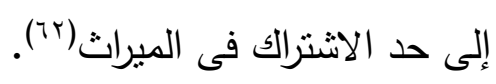

ولم يكتف بهذا الحد بل أنه صلى الله عليه وسلم قد وصل لأبعد من ذلك، فقد زوج

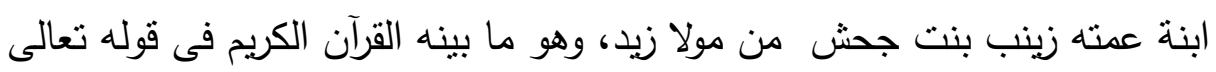

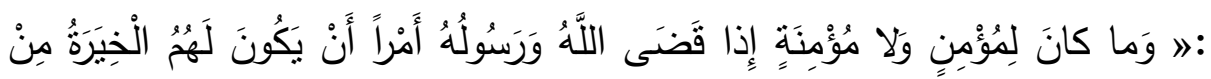

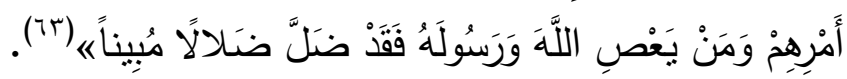
روي أن هذه الآية نزلت في زينب بنت جحش - رضي الله عنها - حينما أراد النبيصلّى اله عليه وسلّم - أن يحطم الفوارق الطبقية الموروثة في الجماعة المسلمة فيرد

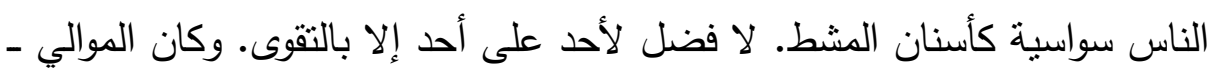
وهم الرقيق المحرر - طبقة أدنى من طبقة السادة. ومن هؤلاء كان زيد بن حارثة لأنة مولى رسول الله - صلّى الله عليه وسلّم - الذي تبناه. فأراد رسول الله صلّّى الله عليه وسلّم أن يحقق المساواة الكاملة بتزويجه من شريفة من بني هاشم، قريبته صلّى الله عليه وسلّم زينب بنت جحش؛ ليسقط تلك الفوارق الطبقية بنفسه، في أسرته. وكانت هذه الفوارق من العمق والعنف بحيث لا يحطمها إلا فعل واقعي من رسول الله

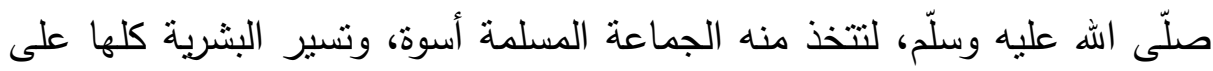
هداه في هذا الطريق(؟). فقد أراد صلى الله عليه وسلم بتلك الحادثة رفع الرقيق إلى مستوى سادات العرب. وظل صلى الله عليه وسلم برعى أحوال الفقراء ويرفع من شأنهم، حتى أنه ما زال

(منهج الإسلام فى القضاء على الرق...) د. صفية محمد محمد سرحان 


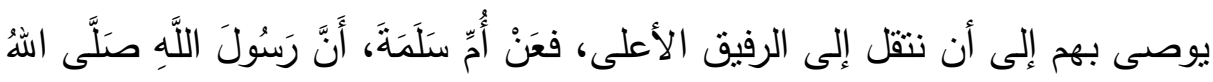

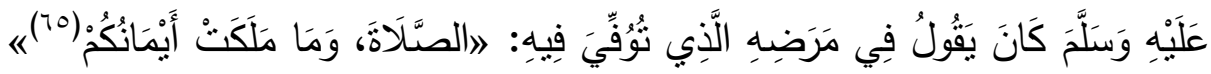

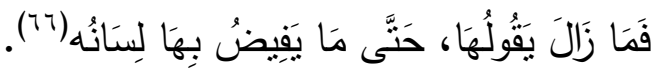
اقتداء الصحابة بالنبى صلى الله عليه وسلم فى الإحسان إلى الرقيق:

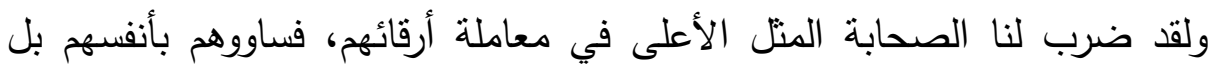

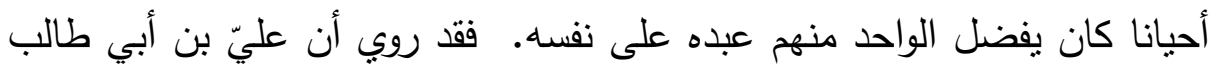

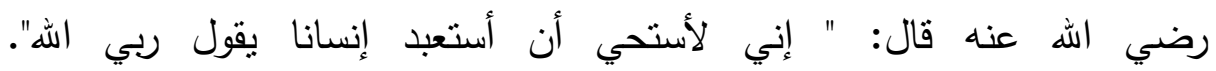

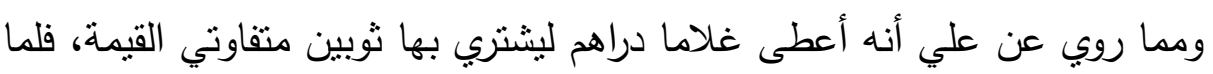

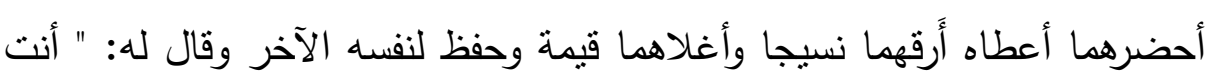

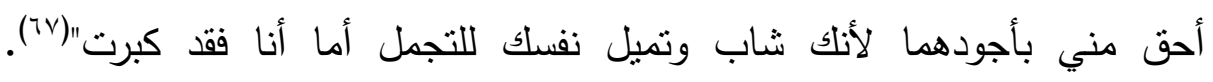

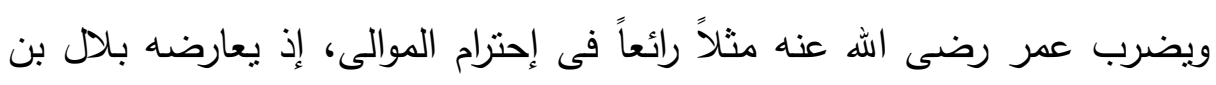

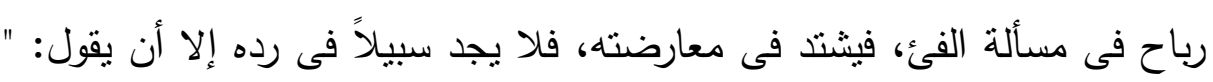

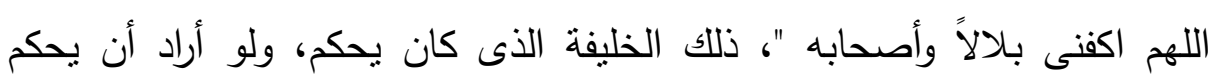

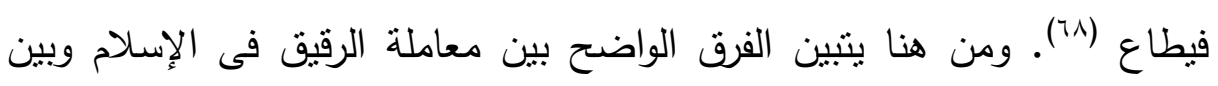

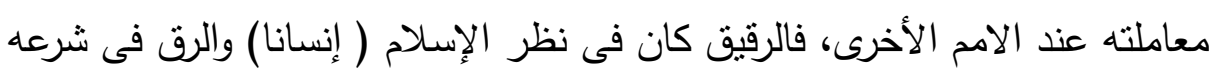
كان حالة إسنثنائية ومؤقته (199). ثانياً: انتقل الإسلام إلى المرحلة الثانية فى معالجة مشكلة الرق، وهى مرحلة التخلص من الرق، وقد اتخذ فى سبيل تحقيق هذا الهدف عدة وسائل منها:

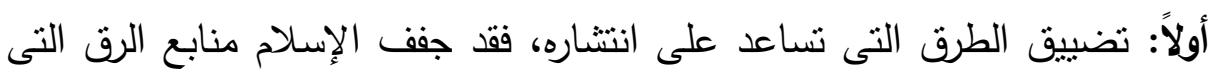

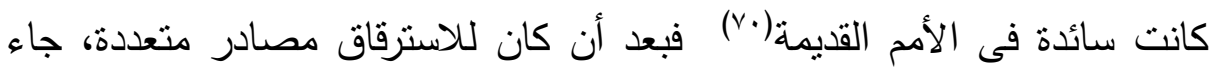

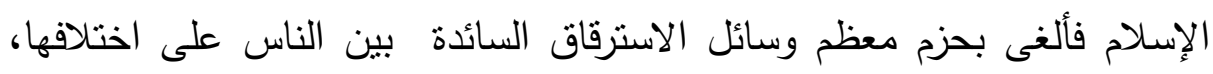

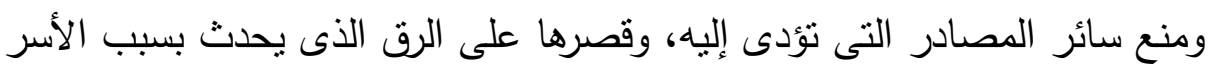

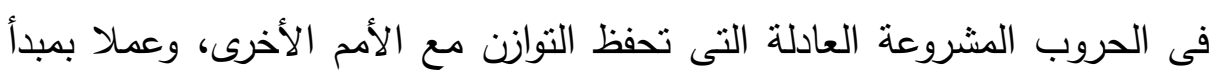

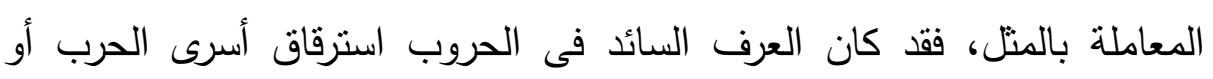

(منهج الإسلام فى القضاء على الرق...) د. صفية محمد محمد سرحان 
قتلهم، وجاء الإسلام والناس على هذا الحال، ووقعت بينه وبين أعدائه الحروب،

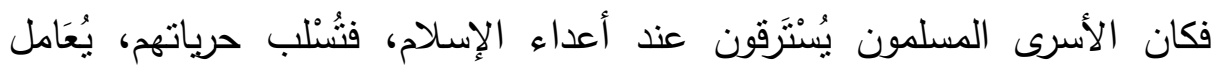

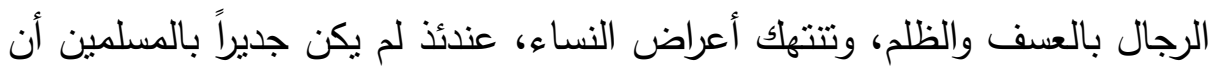

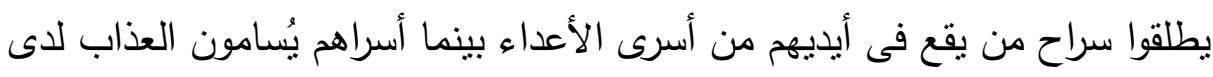

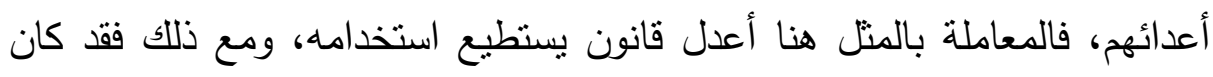
هناك فروق كبيرة بين الإسلام وغيره من النظم الأخرى فى شأن الحرب، وأسرى

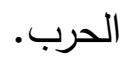

فقد ارتقى الإسلام بمفهوم أسير الحرب مرتقى لم تبلغه أحدث الأنظمة التي تواضعت عليها شعوب العالم المتحضر في القرن العشرين. فعندما تستدعى الضرورة استبقاء أسرى الحرب تحت أيدي المسلمين - ـ وذلك حينما

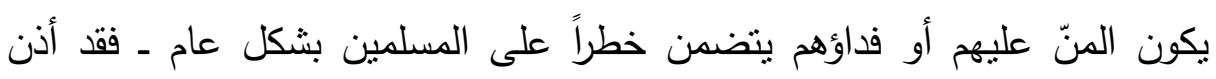
الإسلام للقيادة العامة أن تختاره ضمن حدود المصلحة العامة الدينية أو السياسية

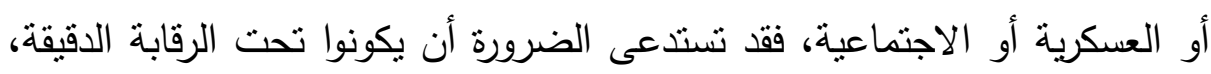
لئلا يكونوا مصدر فتتة وشغب وخيانة وتآمر على المسلمين من داخل صفوفهر.

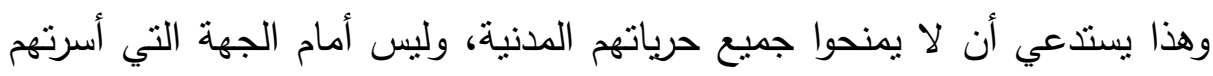
إلا طريقان:

الطريق الأولى: أن يحتجزوا داخل سجون جماعية يقدم لهم فيها طعام خاص بهم،

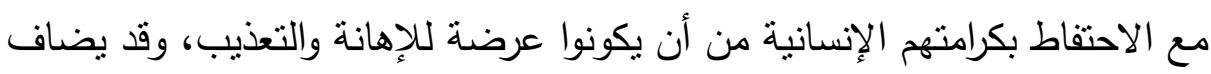

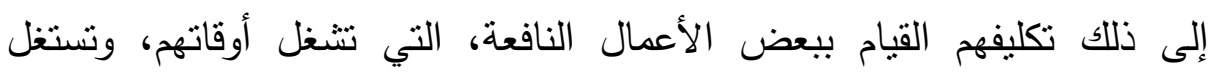
طاقاتهم، وتكون رياضة لأجسامهم. وهذا حل من الحلول التي يضعها الإسلام بين يدي القيادة الإسلامية، لها أن تختاره

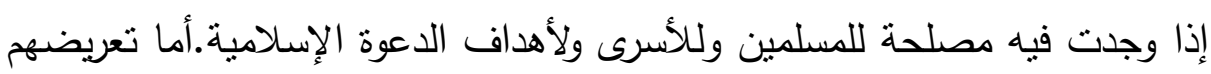
للإهانة والتعذيب، وتقتير النفقة، وتكليفهم الأعمال الثاقة - وهو ما تمارسه دول كثيرة متحضرة - فهذا أمر لا يسمح به الإسلام.

(منهج الإسلام فى القضاء على الرق...) د. صفية محمد محمد سرحان 
وهى فى نفس الوقت منحت الأسرى حرية الدين والعبادة والتعلم، وقد تمنح لهم حرية العمل والتملك إذا أذن لهم أولياؤهم بذلك، أو كاتبوهم لتحرير أنفسهم بما يكسبون من مال. وقد وضع الإسلام هذا الحل بين يدي القيادة الإسلامية، فلها أن تختاره إذا وجدت فيه مصلحة وخيراً للإسلام والمسلمين، ومصلحة للأسرى نفسهم. وقد ألح الإسلام مع ذلك على تحرير الأسرى، وأوجب في كثثر من الحالات تحرير من آمن منهم وصلح واستقام. ويظهر أن الإسلام في هذا قد اختار أن يضع الأسرى موضع نكريم في مجالات

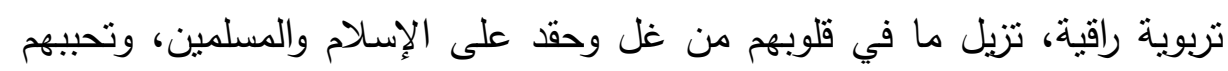

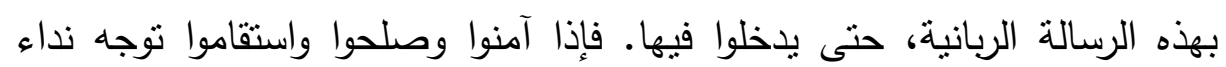

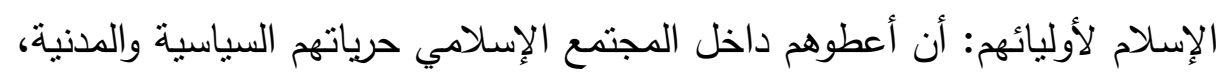

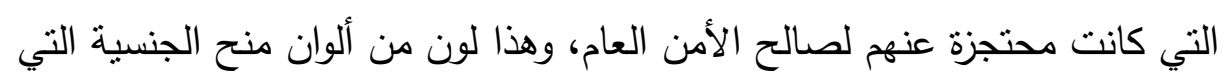

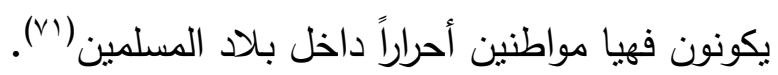
ثانياً: طريق التحرير: ثم انتقل الإسلام إلى تحرير الأرقاء تحريراً كاملاً ، فقتح أبواب تحرير الأرقاء على مصاريعها، واتخذ فى سبيل تحقيق ذلك وسيلتين هما:

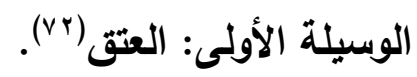

وكان رسول الله صلى الله عليه وسلم القدوة الأولى فى ذلك إذ أعتق من عنده من

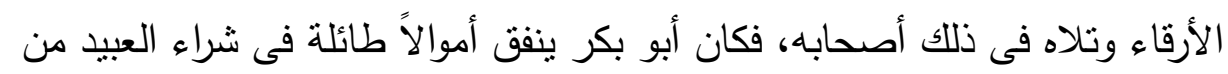

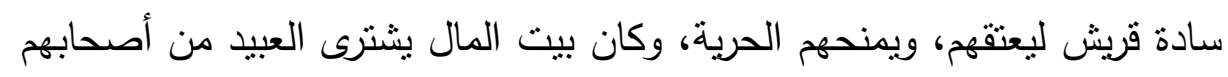

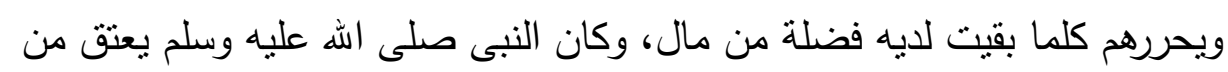
الأرقاء من يعلم عشرة من المسلمين القراءة والكتابة، أو يؤدى خدمة ممانلة ملثة للمسلمين. ثم فتح الإسلام منافذ عديدة لإنهاء الرق ورغب فيها، وقد جعل اله عز وجل لتخليصهم من ذل الرق عدة أسباب ذكر القرآن الكريم منها: لإنهاء لترعاء

(منهج الإسلام فى القضاء على الرق...) د. صفية محمد محمد سرحان 


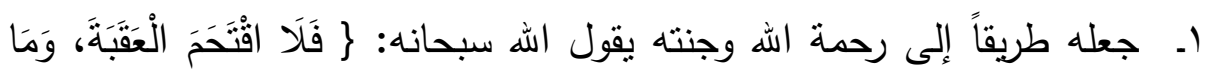

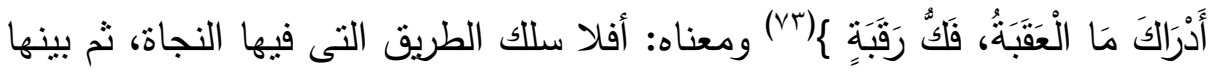

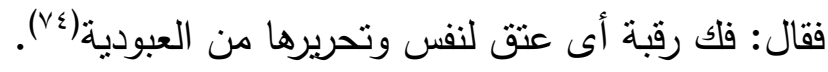

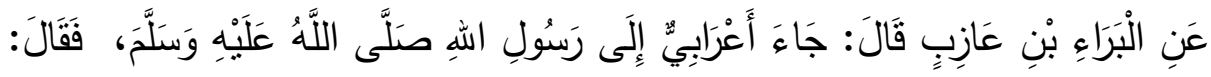

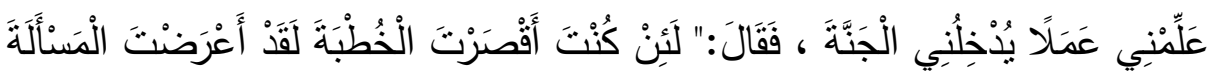

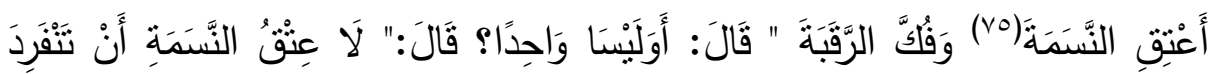

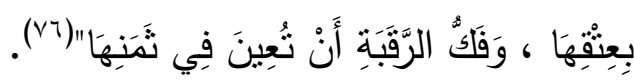
r - جعله كفارة لبعض ما يقترفه الإنسان من الذنوب منها:القتل الخطأ. يقول الله

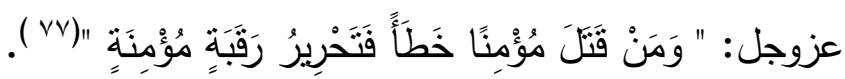
وفى هذه الكفارة دلالة خاصة فى نظر الإسلام إلى الرق، فقد جعل كفارة القتل

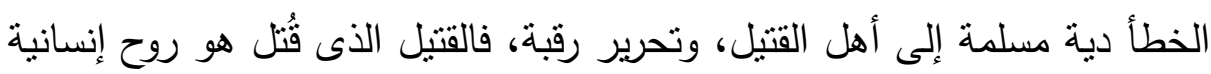

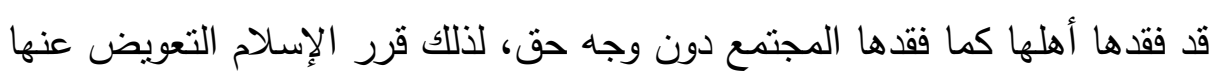
من جانبين. التعويض لأهلها بالدية المسلمة لهم، والتعويض للمجتمع بتحرير رقبة مؤمنة، فكأن تحرير الرقبة هو إحياء لنفس إنسانية تعويض النفس التى ذهبت بالقتل، فالرق على بلى

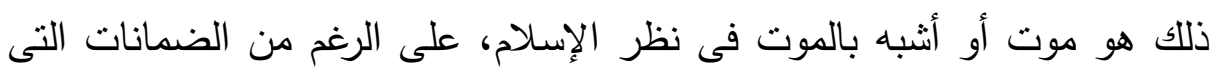

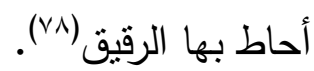

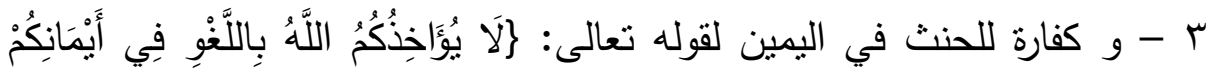

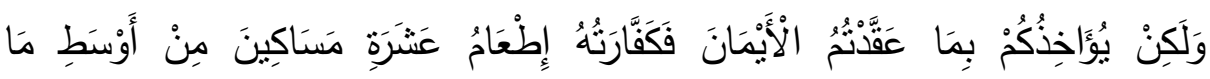

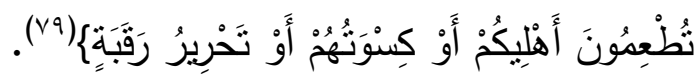

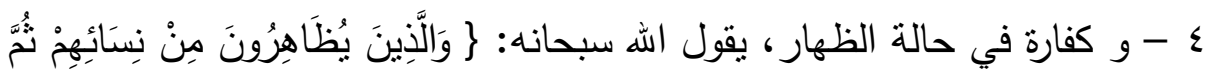

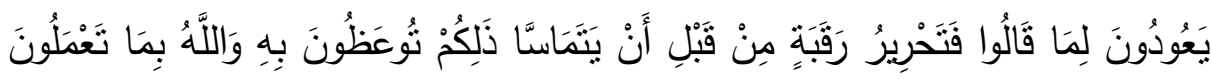
خَبير $\left\{\cdot{ }^{(\wedge}\right.$

(منهج الإسلام فى القضاء على الرق...) د. صفية محمد محمد سرحان 


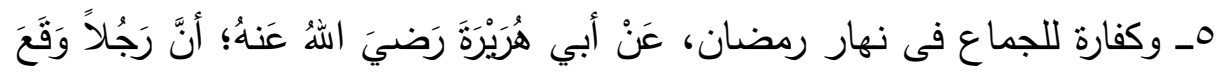

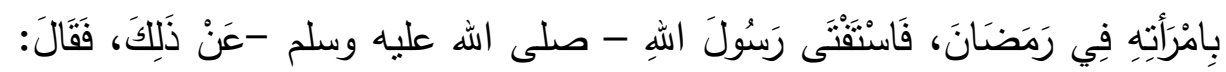

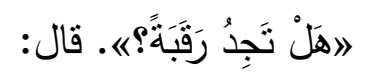

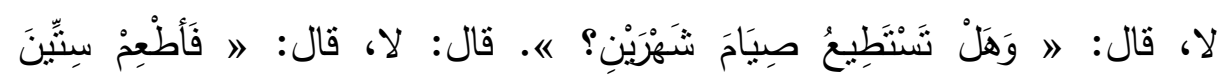

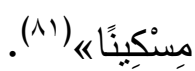

فالحديث يوضح أن الكفارة واجبة على من جامع في نهار رمضان متعداً ، وأنها

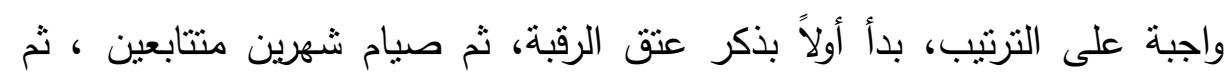
إطعام ستين مسكيناً.

דـ جعل الإسلام للإعتاق بابا من أبواب الزكاة، فقسمها سبحانه وتعالى بنفسه

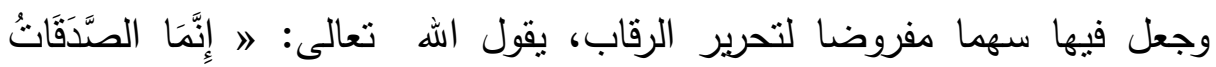

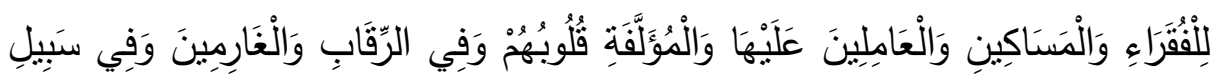

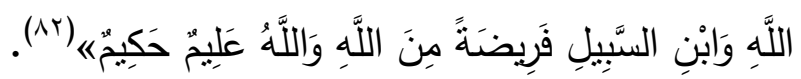
دور السنة فى الترغيب فى العتق: وبجانب القرآن نجد للسنة دور واضحاً فى التزغيب فى العنق والحث عليه ويتمثل ذللك فى: الهُ اله اــ أن من أوجب على نفسه تحرير رقبة بالنذر وجب عليه الوفاء به منى تحقق له

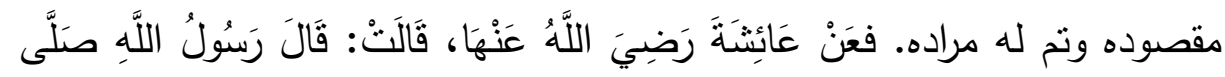

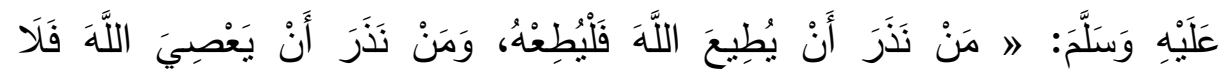

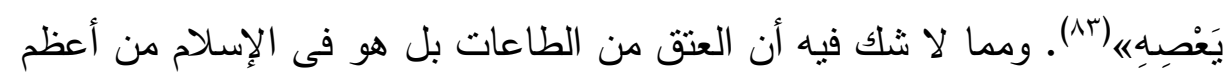

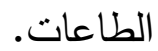

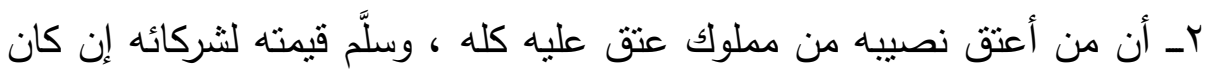

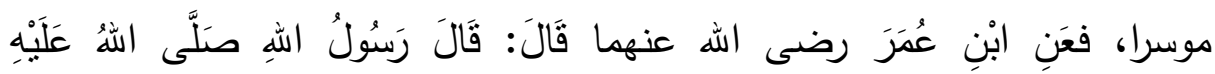

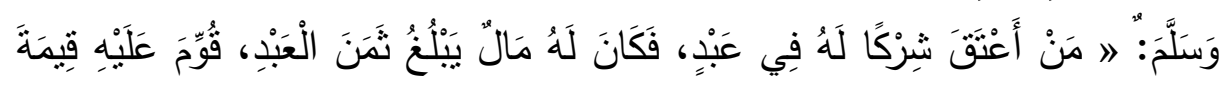

(منهج الإسلام فى القضاء على الرق...) د. صفية محمد محمد سرحان 


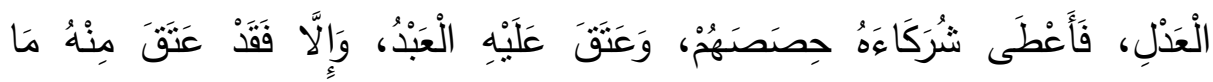

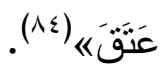
rـ كذلك من ملك ذا رحم محرم عليه كأبيه وأخيه وعمه وخاله، وأمه وعمته وخالته

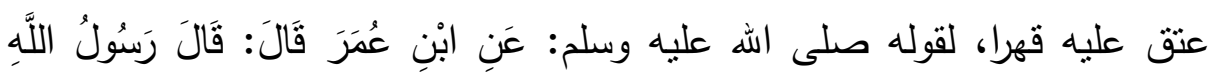

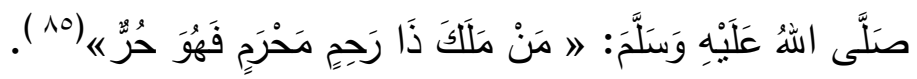

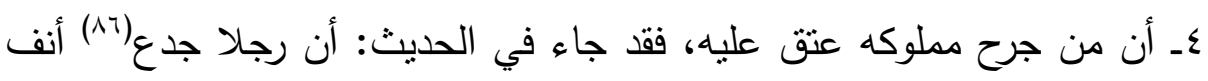

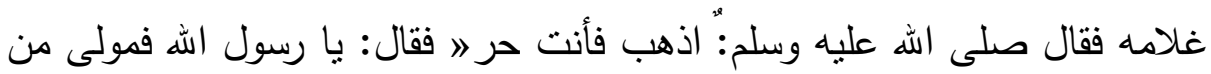

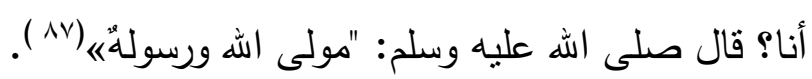

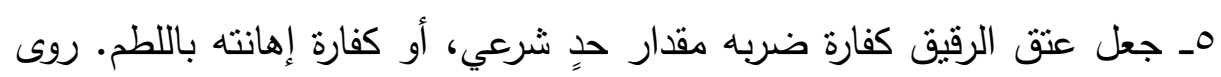

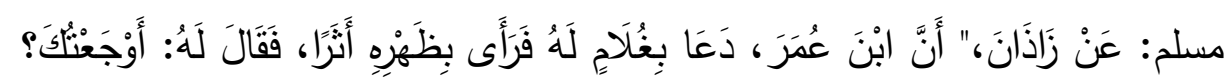

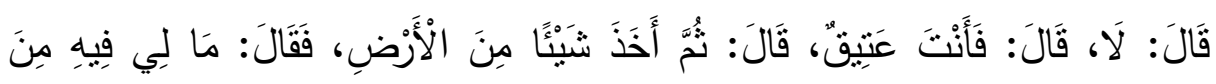

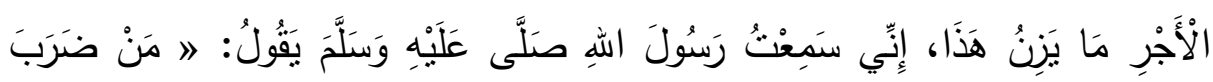

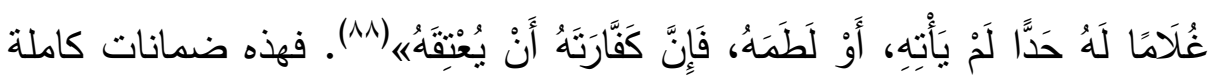

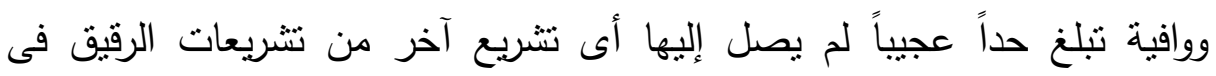

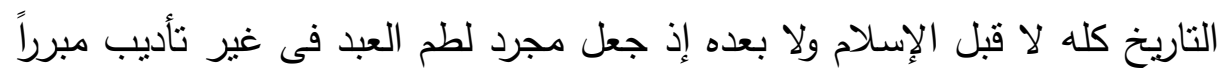

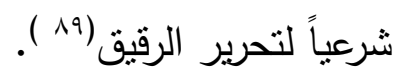

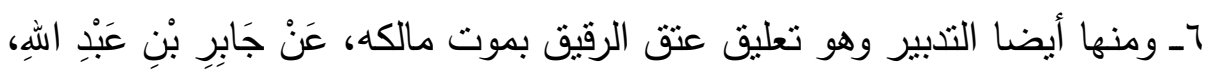

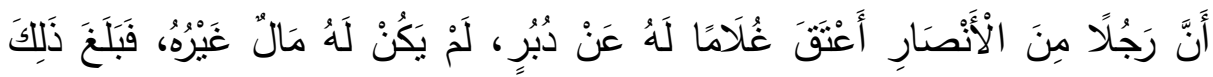

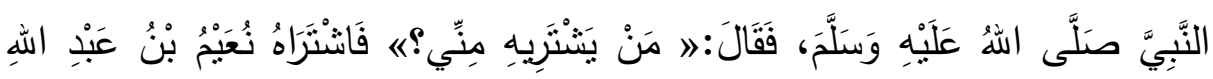

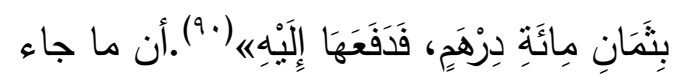

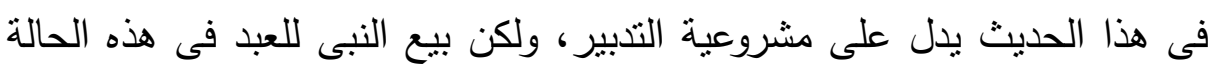

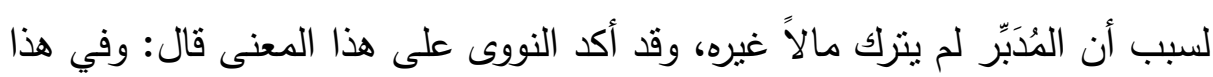

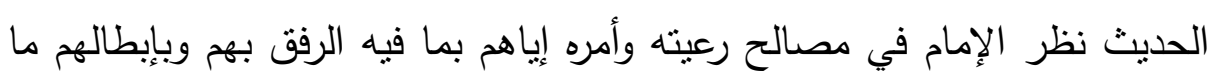

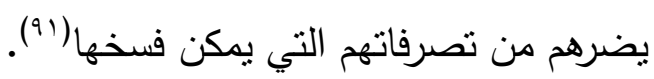

(منهج الإسلام فى القضاء على الرق...) د. صفية محمد محمد سرحان 
Vـ ومنها الاستيلاد، وهو إنجاب الأمة من سيدها، إذ يكون ولدها سبباً في تحريرها بعد موت سيدها.لأنها تصبر أم ولد له، لحديث ابْنِ عَبَّاسِ قَالَ: قَالَ رَسُولْ اللَّهِ

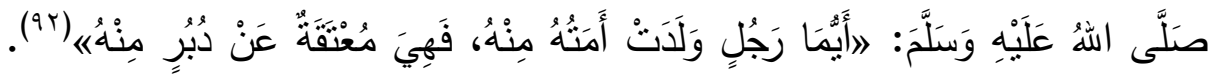
وذلك خلاف ما كان معمولا به فى المجتمعات غير المسلمة حيث كان من وسائل الاسترقاق تتاسل الأرقاء كما سبق ذكره. الوسيلة الثانية المكاتبة(ب9):

المكاتبة، وتعني منح الحرية للرقيق منى طلبها بنفسه مقابل مبلغ من المال يتقق

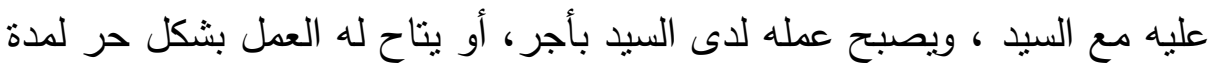
زمنية، ترفع عنه فيها جميع القيود الاقتصادية التي كانت مفروضة عليه، ليشتري حرية نفسه بمال يتفق هو وسيده عليه، ويسعى في اكتسابه خلال هذه المدة،

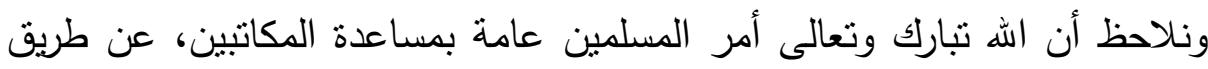

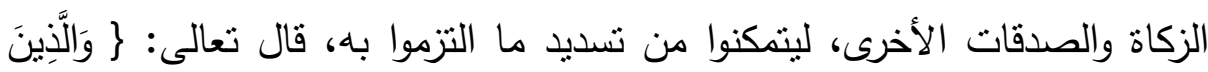

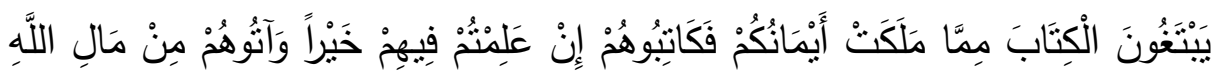

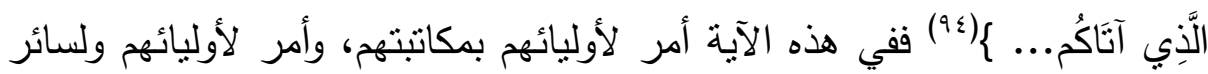

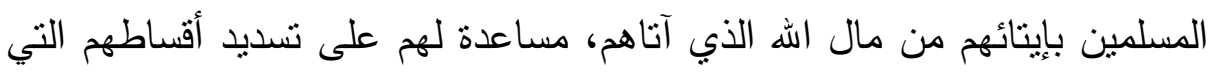
يتوقف عليها تحريرهم. وقد نص كثير من الفقهاء على أنه يجب على السيد مكاتبة عبده، إذا طلب ذلك منه، وراى فيه خيراً من صدق ووفاء وأمانة وأداء للحق، وإيمان صحيح (90.

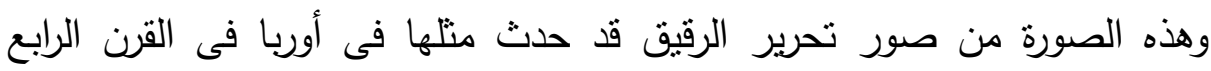

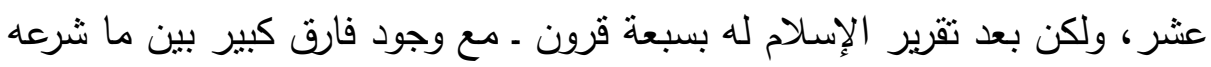

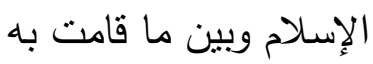
أوربا تجاه الرقيق، ففى حين كانت الثربعة الدولية لم تعرف فكاك رعاياها من

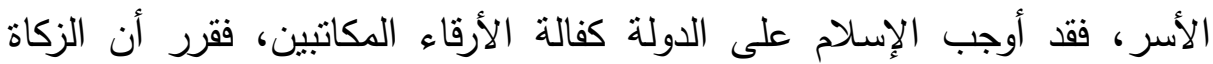
تصرف من بيث المال ـ وهو الخزانة العامة فى العرف الحديث ـ لمعاونة المكاتبين

(منهج الإسلام فى القضاء على الرق...) د. صفية محمد محمد سرحان 
لأداء ثمن التحرير، إذا عجزوا بكسبهم عن أدائه، فال تعالى: \} إنَّمَا الصَّدَقَاتُ

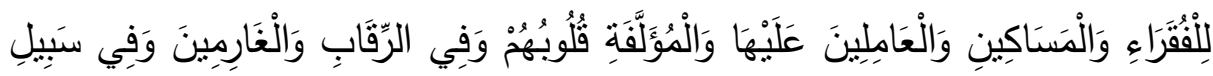

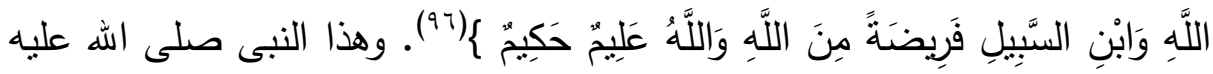
وسلم يُرسى ذلك المبدأ ويرسخه فى نفوس الصحابة ، فيعاون بنفسه سلمان الفارسى ولى على مكاتبته، فغرس لله بيده الكريمة ثلاثمائة نخلة. فقد طلب صلى الله عليه وسلم منه أن يكاتب سيده لما فاته حضور بدر وأحد مع النبى صلى الله عليه وسلم بسبب الرق، فقال سلمان: فلم أزل بصاحبى حتى كاتبته على أن أغرس له تلثنمائة

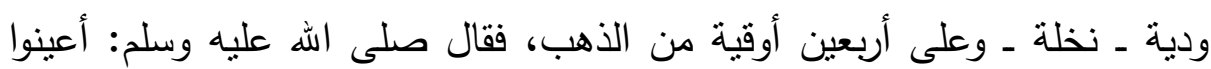

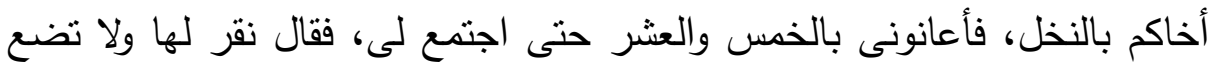

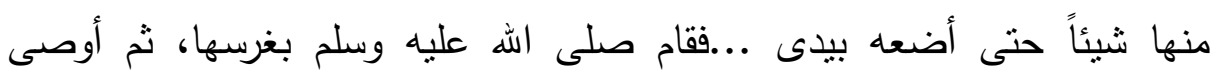

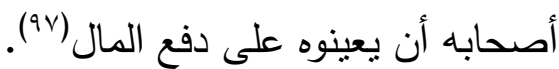
وقد كان للنساء من الرقيق نصيباً من الحظوة والاهتمام، وهو ما فعلته السيدة عائشة رضى الله عنها لما جاءتها بربرة تستعينها فى كتابتها ولم تكن قضت من كتابتها شيئاً، فقالت لها عائشة ارجعى لأهلك، فإن أحبوا أن أقضى عنانك كتابتلك،

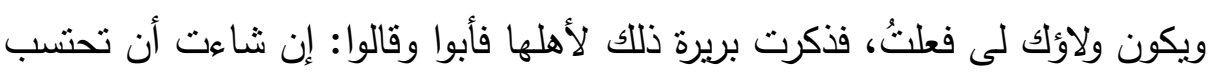
عليك فلتفعل ويكون ولاؤك لنا، فذكرت عائشة للنبى صلى الله عليه وسلم ذللك، فقال

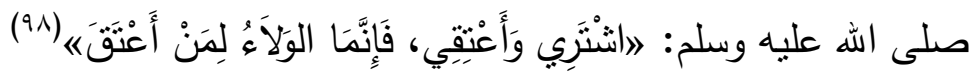

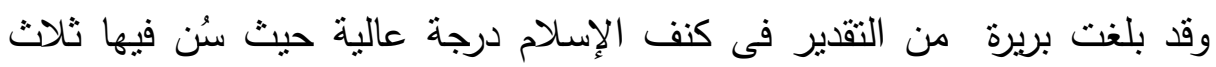

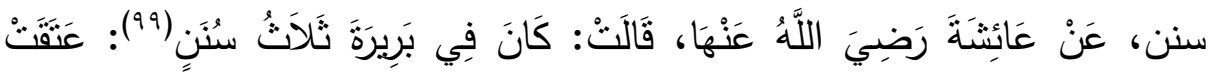

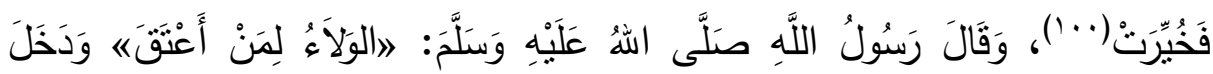

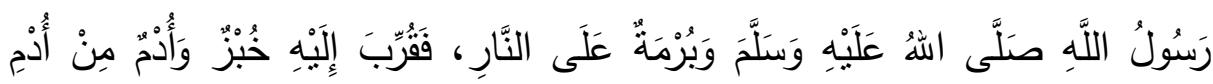

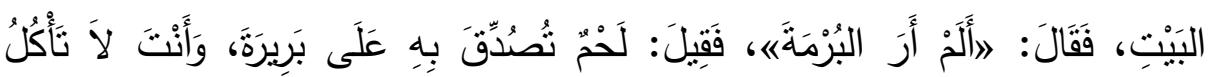

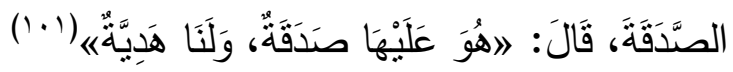

(منهج الإسلام فى القضاء على الرق...) د. صفية محمد محمد سرحان 
فبذلك يكون الإسلام قد خطا خطوات فعلية واسعة فى سبيل تحرير الرقيق، وسبق

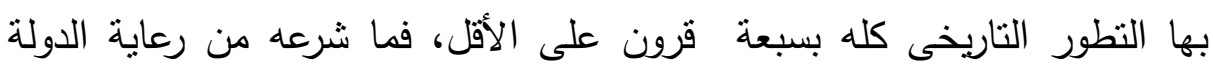

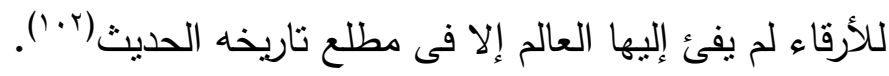
أثر الرقيق فى حياة الدولة الإسدلامية:

كان سبب الرق في الإسلام وقوع الكافر أَسير في يد المسلمين عند الحرب، فإذإِا

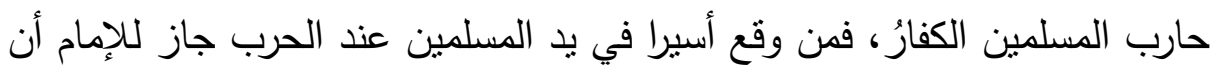

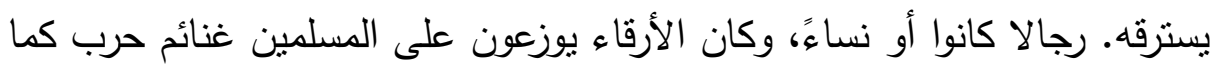

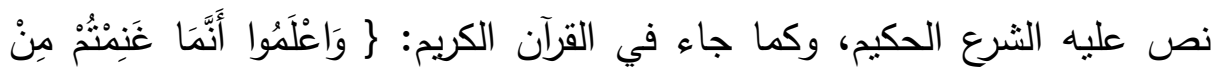

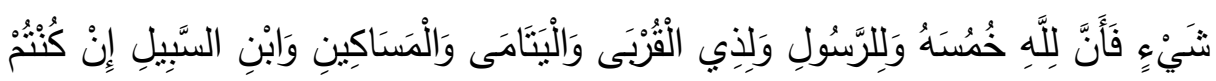

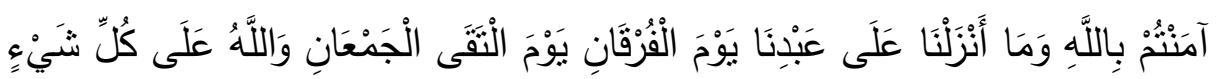

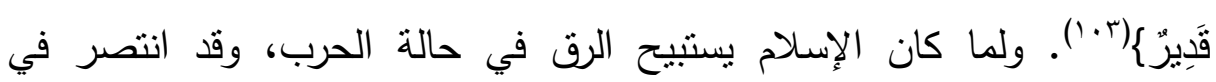

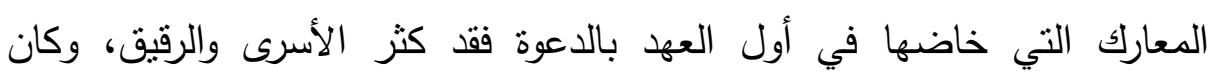
وجودهم مع العرب بالكيفية التي حث الإسلام على اتباعها معهم له أكبر الأثر في عملية المزج بين العرب وغير العرب، حيث فتحت بلاد كثيرة من غير العرب في الثام والعراق وبلاد فارس ومصر وشمال إفريقيا على مر العصور والأزمنة، فامتزج

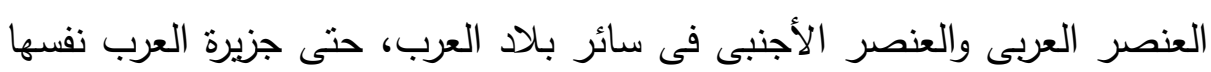

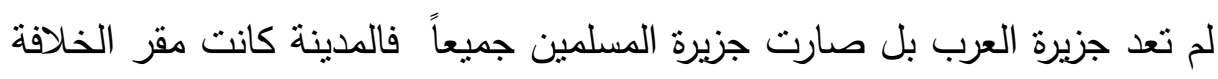

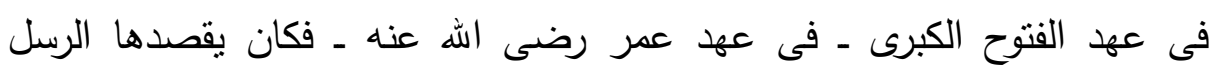
وذوات الحاجات من الأمم الأخرى، وكذلك كان يأنى إليها الأسرى من البلاد المفتوحة طبقا لتعاليم عمر بعدم توزيع الغنائم إلا فى مقر الخلافة، فامتلأت المدينة وما حولها بالعناصر الغير عربية. غير أن مكة والمدينة كانتا مقصد الحجاج

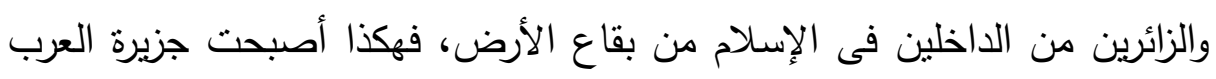

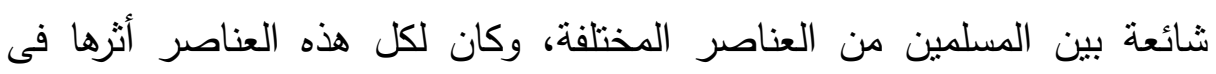
المجتمع المسلم، فقد أثروا فى كل نواحى الحياة ، السياسية والاجتماعية

(منهج الإسلام فى القضاء على الرق...) د. صفية محمد محمد سرحان 
والاقتصادية ، وفى الحياة الفكرية والعقلية، حتى العقيدة واللغة لم يكونا بعيدين عن

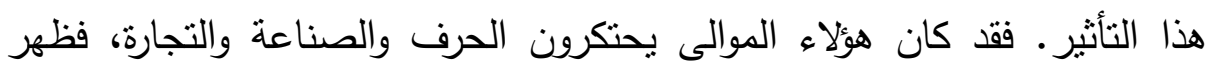

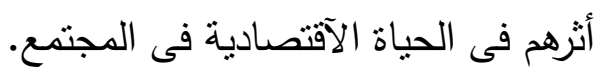

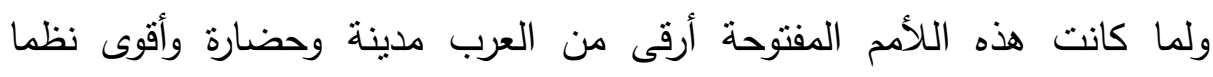

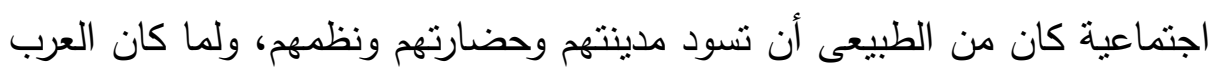

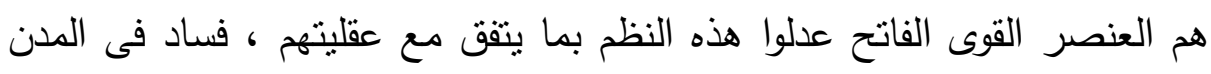

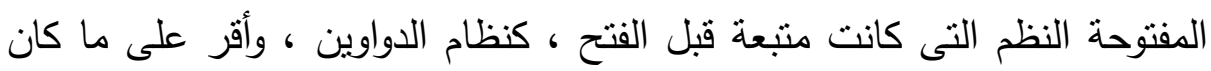
عليه. (- مان.

\section{أما أثرهم فى الحركة العقلية: - مانه}

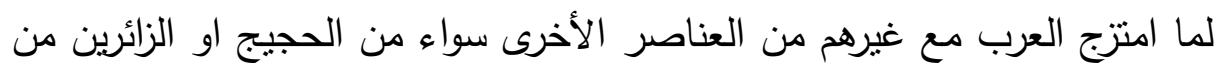

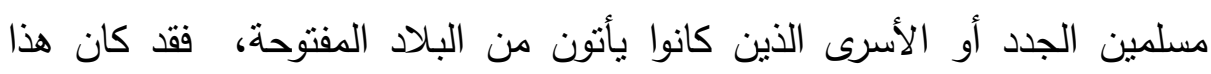

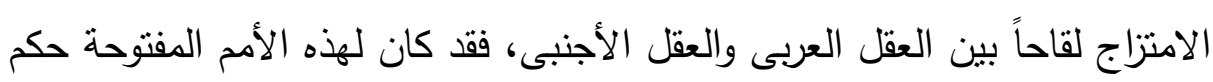

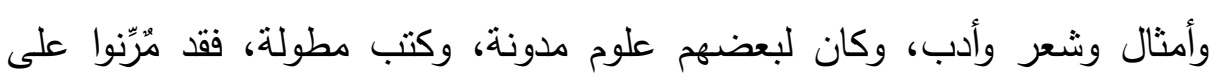

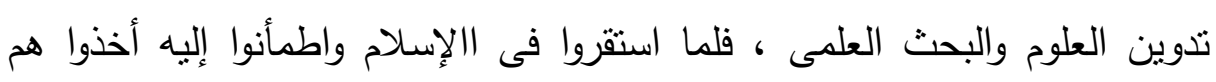

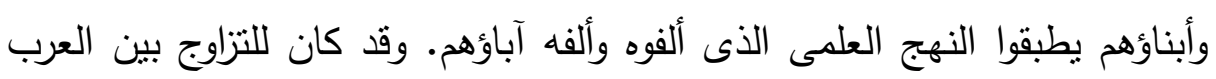

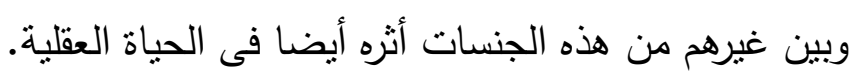

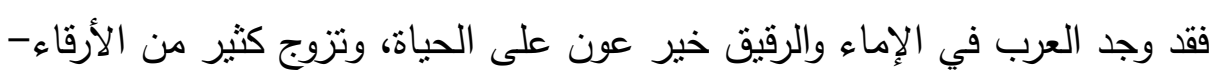

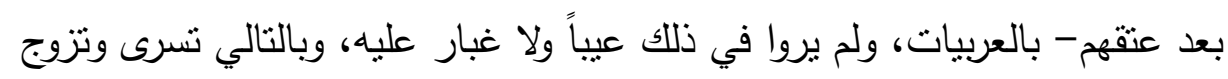

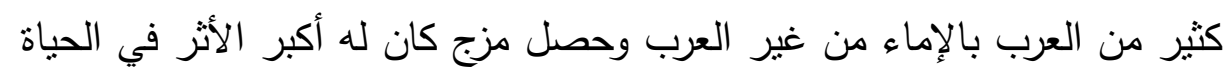

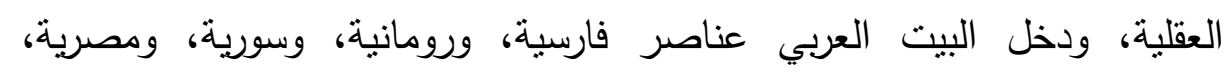
وبربرية. وبطريق التناسل اختلط الدم العربي بغيره من الدماء، فأنتج أعظم العقول

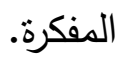
يقول الزمخشري في كتابه ربيع الأبرار : "إن الصحابة رضي الله عنهم لما أنوا

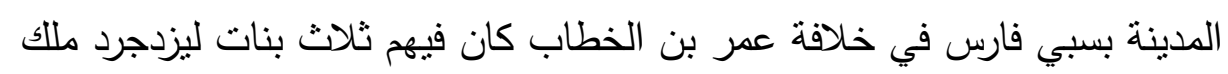

$$
\text { (منهج الإسلام فى القضاء على الرق...) د. صفية محمد محمد سرحان }
$$


الفرس، فباعوا السبايا وأمر عمر بييع بنات يزدجرد أيضا، فقال له علي بن أبي

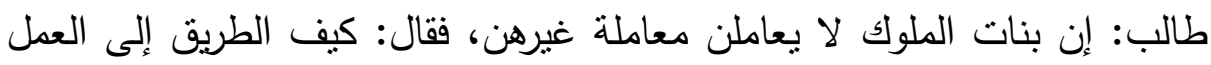

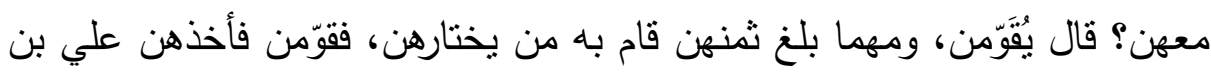

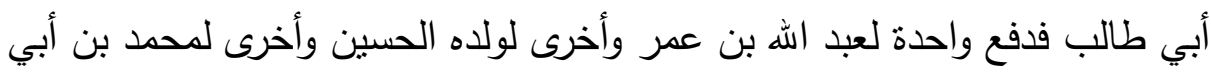
بكر الصديق، فأولد عبد الله بن عمر ولده سالما، وأولد الحسين زين العابدين، وأولد الدان

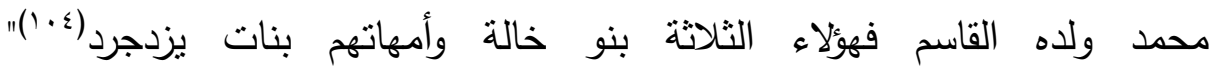
وروى ابن عساكر بسنده عن الأصمعي عن أبي الزناد قال كان أهلان أهل المدينة

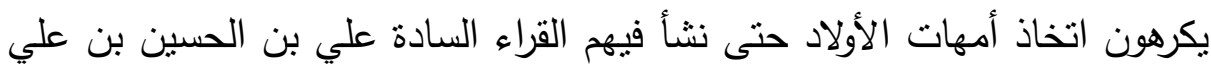

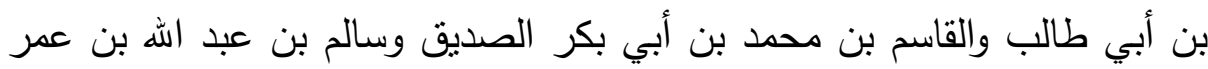

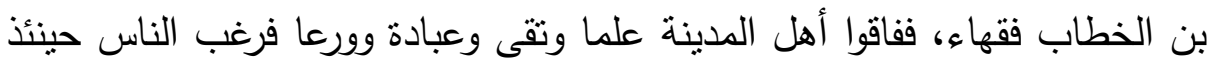
في السراري(1.0) ويقول أحمد أمين رحمه الله: "هؤلاء الأرقاء والموالي أنجبوا في الجيل الثاني لعهد

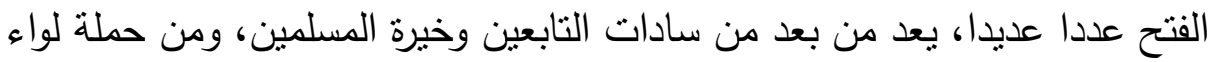

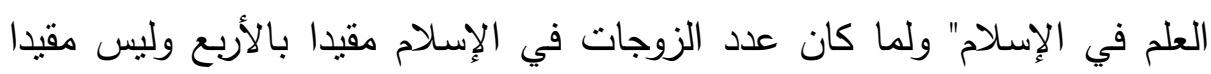

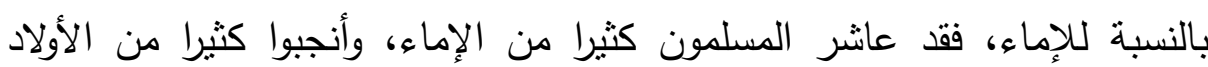

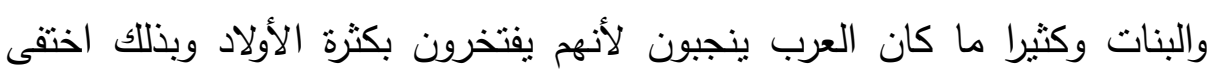

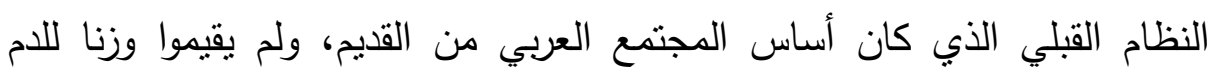

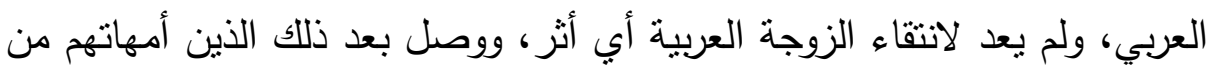
الرقيق إلى الخلافة مثل بزيد الثالث في الخلافة الأموية فإن أمه غير عربية، فقداء التردية

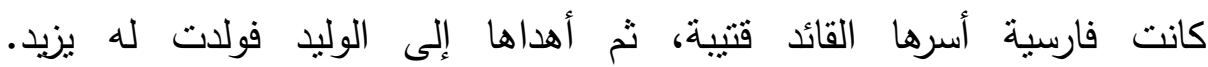
وكنلك العباسيون ، فالمنصور ابن أمة من البربر والمأمون ابن أمة فارسية، ومنله

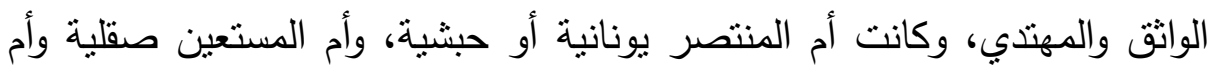

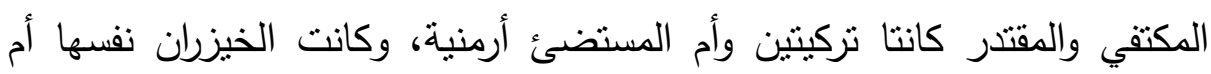

(منهج الإسلام فى القضاء على الرق...) د. صفية محمد محمد سرحان 
الرشيد أجنبية وهي أول امرأة اضطلعت بسلطة واسعة في شئون الدولة العباسية.

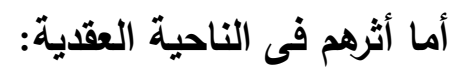

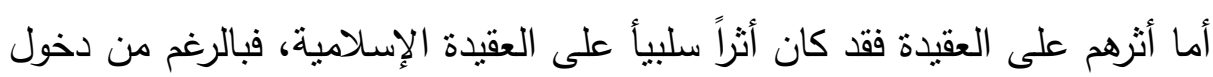

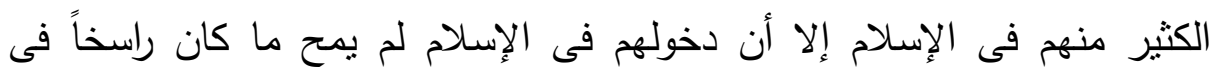

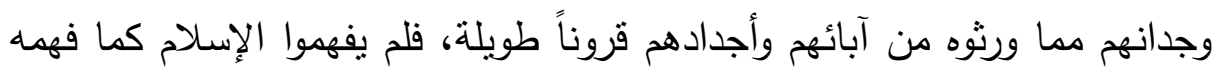
العرب، حتى المخلصون منهم كان اعتتاقهم للإسلام مشبوهاً بتقاليدهم الدينية القديمة ، فقد كانت لهم عصبية سياسية غير العصبية العربية، وتقاليد دينية لابد

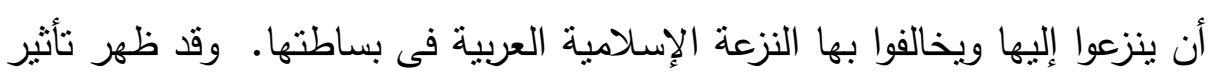
هؤلاء القوم فى أواخر القرن الأول الهجرى بظهور المذاهب المختلفة، وأظهرها التشيع والتصوف. التصاء كما كان لهم أثز سيئ ظهر فى بعض الأحداث، كأدراك أبنائهم قتال صفين.

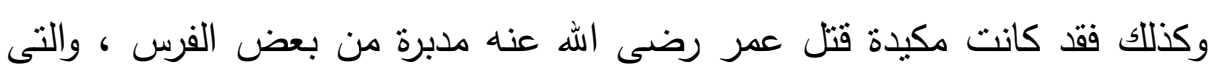
نفذها أبو لؤلؤة المجوسى.

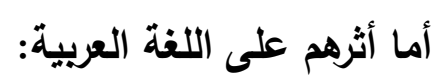

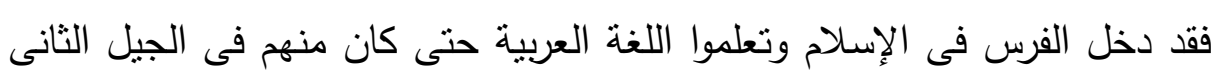

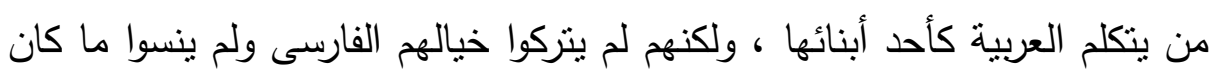
لقومهم من شعر ومثل وحكمة ، فكان من أثر ذلك أن امتلأ الأدب العربى بالحكم الفارسية، والقصص الفارسية، والخيال الفارسى ( + (1).

\section{اتجاه الدولة بالرقيق غير الاتجاه الإسلامى لا يقلل مما قدمه الإسلام للرقيق:}

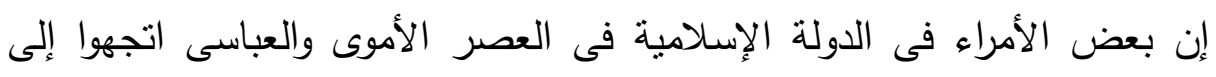
التوسع فى الاعتماد على الرقيق فى الجيش وفى وظائف الدولة المختلفة، فدخلوا

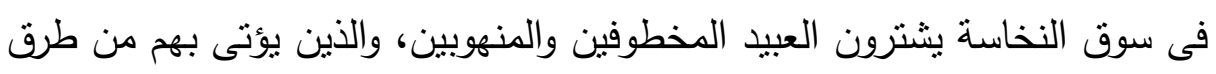

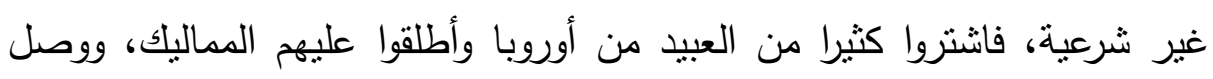

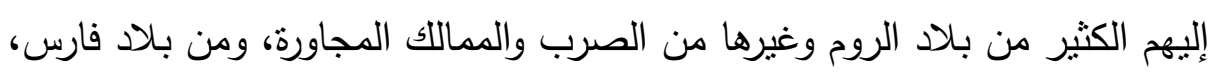

$$
\text { (منهج الإسلام فى القضاء على الرق...) د. صفية محمد محمد سرحان }
$$


واتخذوا منهم العسكر والجيوش التي يحاربون بها بعضهم والممالك المجاورة، ومن

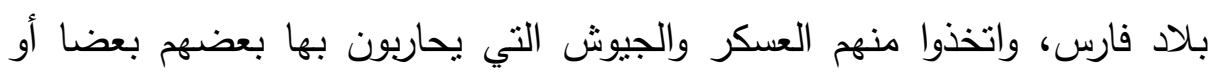

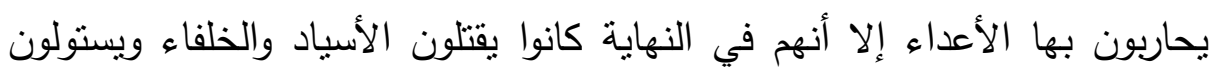

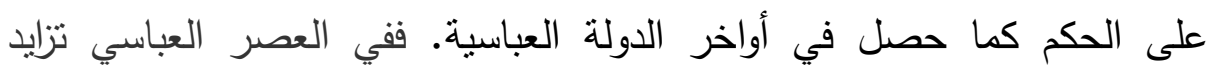
استخدام الأترالك في وظائف الدولة وفي الجيش، وتوسعت أسواق النخاسة البيضاء،

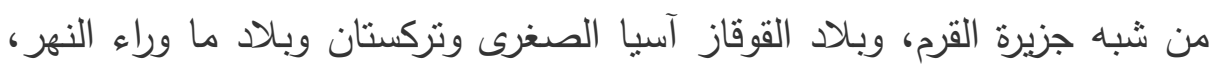
وكان فيهم عنصر الأتراك، وفيهم الثراكسة والروم والأكراد وبعضهم من البلاد

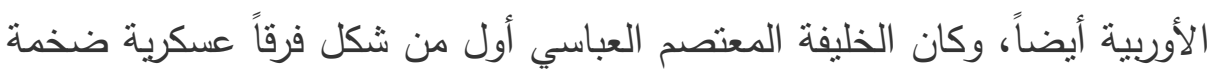

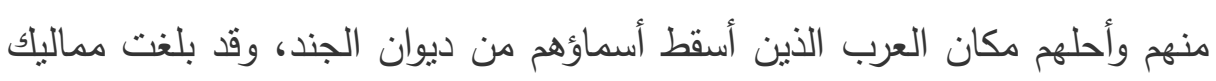

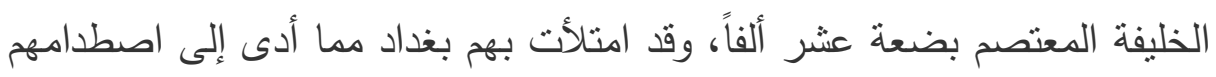

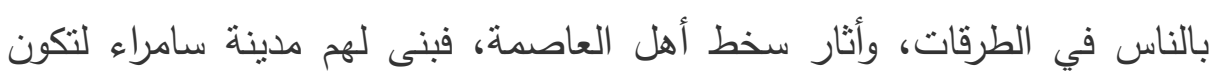

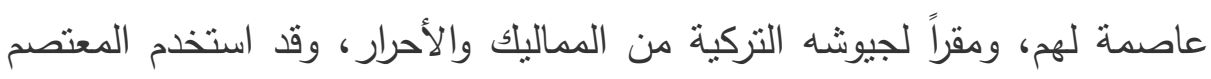

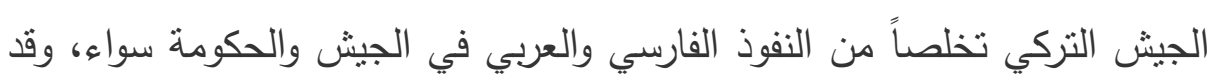
لجأ إلى الأتراك بالشراء والتربية والإعداد إعتقاداً منه بأنه مجردون من الطموح الذي الذي اتصف به الفرس، ومن العصبة التي عرف بها العرب، ولكن سرعان ما أخذ أولئك المماليك في التذخل في شئون الدولة حتى أمست في أيديهج يفعلون بها ما يشاؤون.

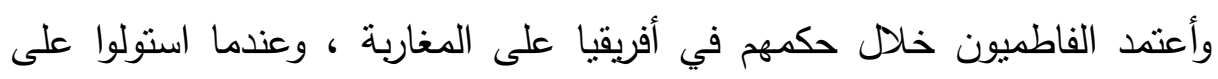
مصر عام 101هـ (979 م) استكثروا من الديلم والأترالك والغز والأكراد. أما الأيوبيون، فإن استكثارهم من المماليك كان سببا في قيام الدولة المملوكية، حيث

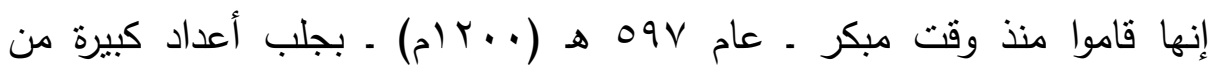
المماليك الصغار عن طريق النخاسين الذين كانوا يحضرونهم من شبه جزيرة القرم،

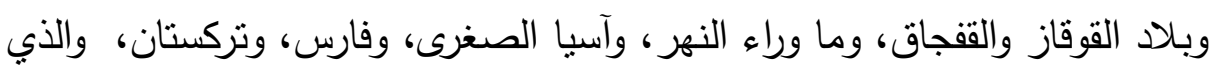

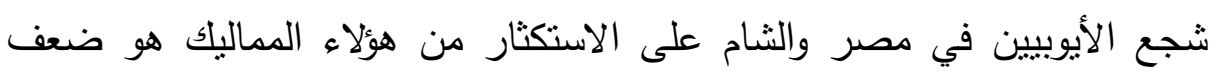

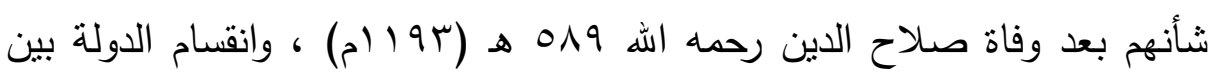

(منهج الإسلام فى القضاء على الرق...) د. صفية محمد محمد سرحان 


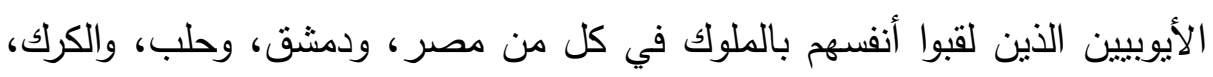

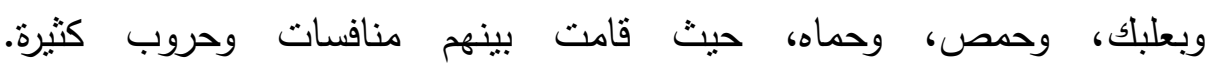
وقد كان السلاطين يشرفون بأنفسهر على تربية مماليكهم ويتفقدون أحوالهم ومنهم

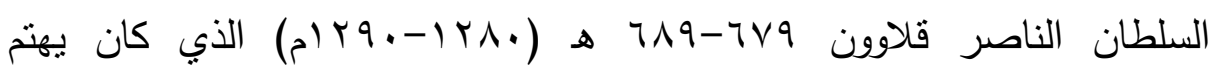

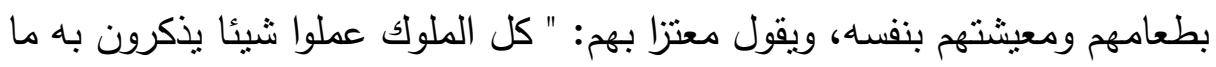

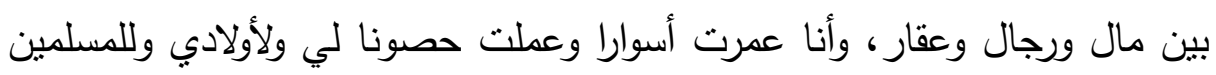

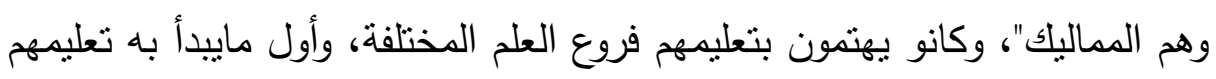

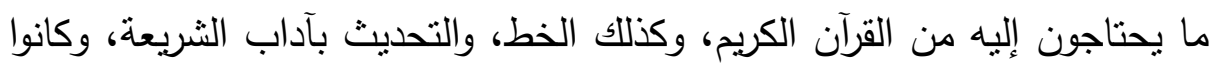

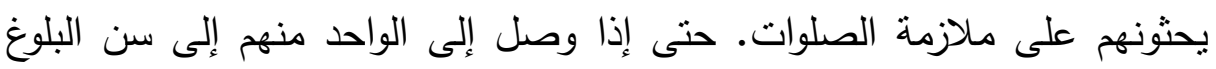

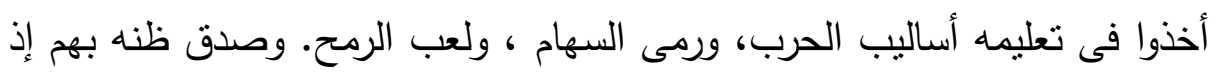

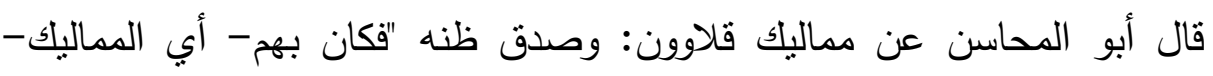

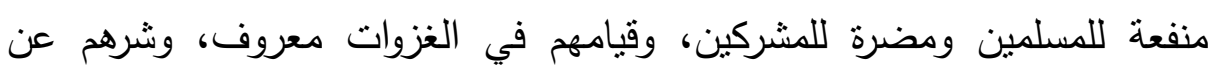

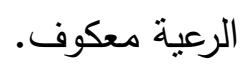

وكان السلاطين ومقدمو المماليك يوصون القائمين على شؤونهم أن يأخذوهم

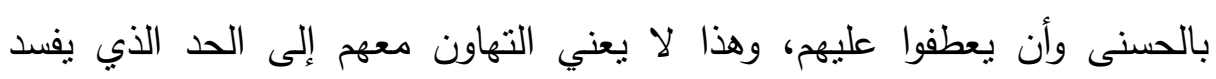

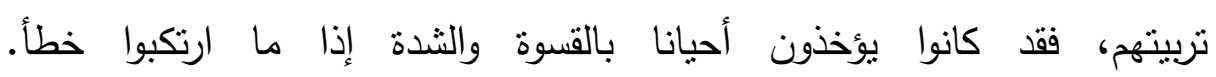

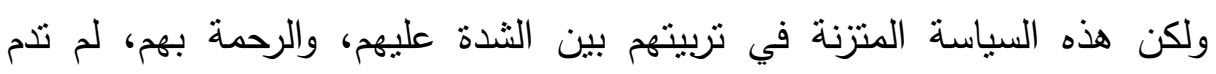

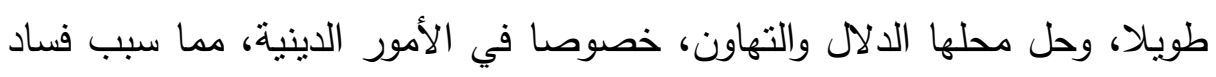

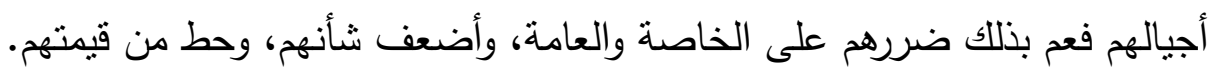

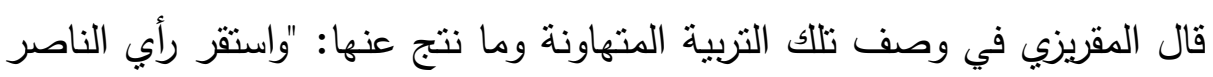

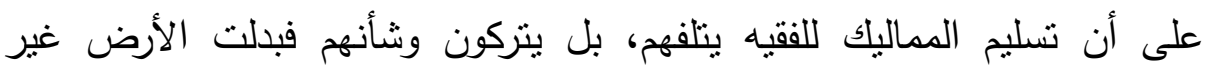

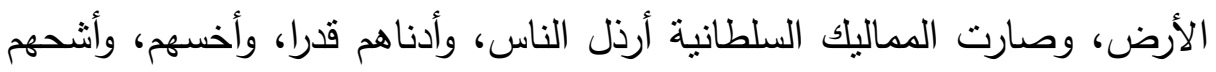

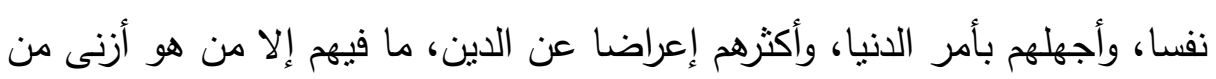

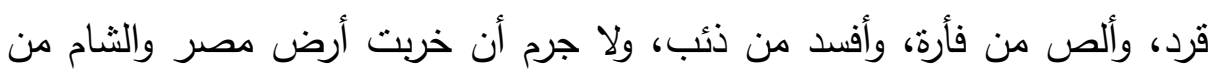

$$
\text { (منهج الإسلام فى القضاء على الرق...) د. صفية محمد محمد سرحان }
$$


حيث يصب إلى مجرى الفرات بسوء إيالة الحكام، وشدة عيب الولاة، وسوء تصرف

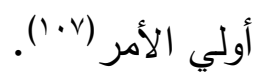
فهولاء المماليك رغم ما نتج عن وجودهم فى الدولة الإسلامية من أثز إيجابى، حيث كان لهم دور كبير فى هزية المغول مرات عديدة، وحالوا بينهم وبين الاتصال

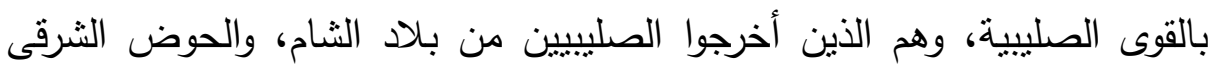
للبحر المتوسط. إلا أن ممارسات الأمراء والتوسع فى جلبهم بهذه الطرق الغير مشروعة التى قد

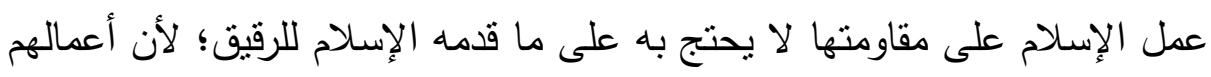

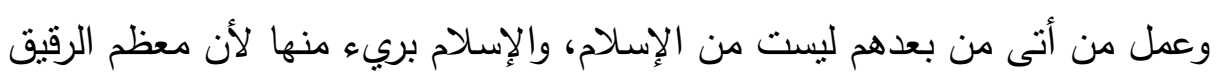

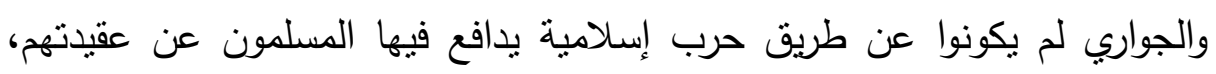

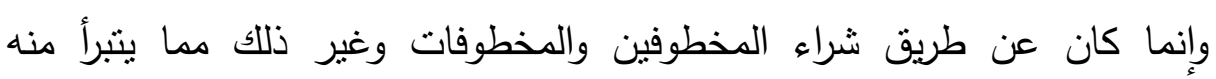
الإسبلام والمسلمون.

الحكمة من الإبقاء على مشروعية الرق فى النصوص الثرعية:

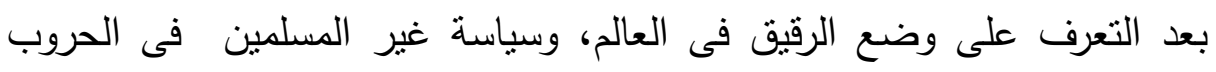

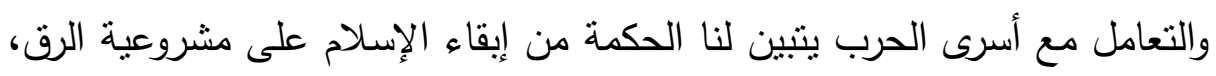

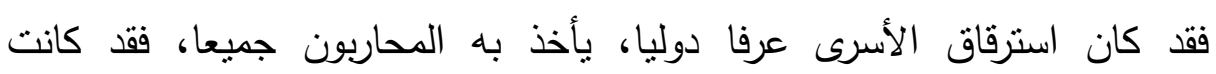

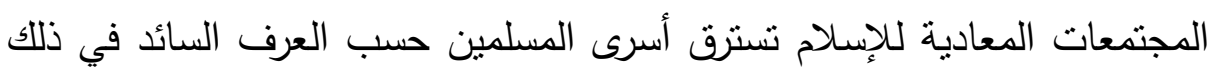

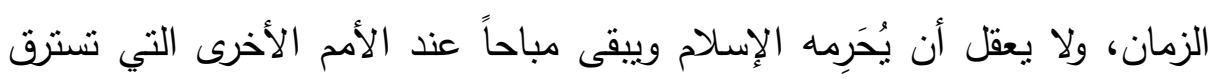

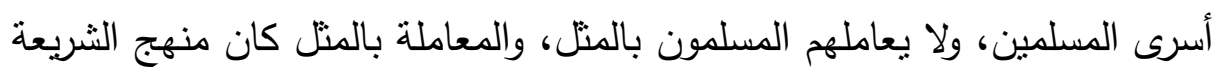
والخلفاء في العلاقات الخارجية، عملاً بأحكام السياسة الثرعية المؤقتة، وتحقيقاً

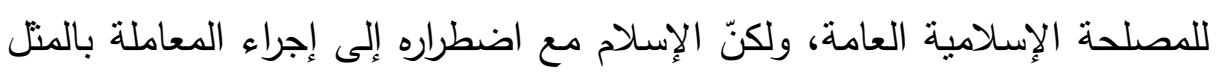

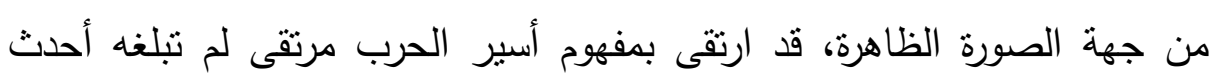
الأنظمة التي تواضعت عليها شعوب العالم المتحضر في القرن العشرين. ففى حين كان الأسرى يسامون كل خسف وتعذيب وتنخير في الأعمال الثقيلة قد أحاط

$$
\text { (منهج الإسلام فى القضاء على الرق...) د. صفية محمد محمد سرحان }
$$


الإسلام أسرى الحرب بعناية شديدة، فقد أمر المسلمين أن يحسنوا معاملتهم، وأن يجعلوهم كأفراد أسرهم.

وبهذه التربية الإسلامية العظيمة صار كثير من الموالي الأسرى من كبار علماء

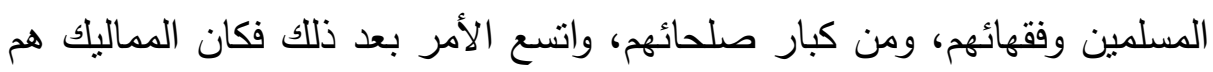

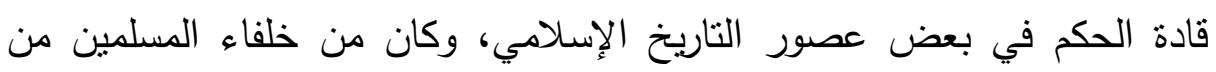

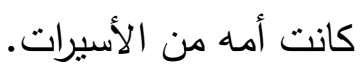

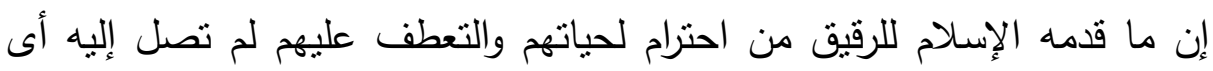

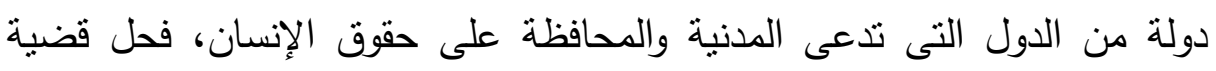

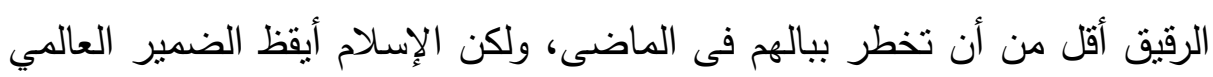

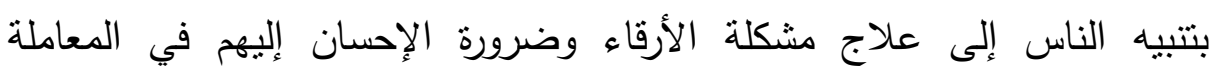
والتخلص التدريجي من هذه الظاهرة بالعتق وفتح منافذ دينية له.

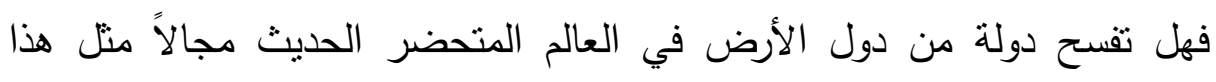

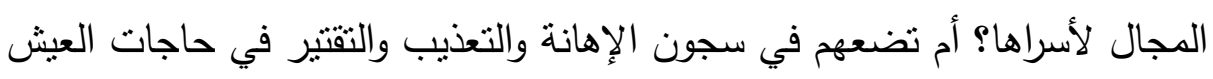

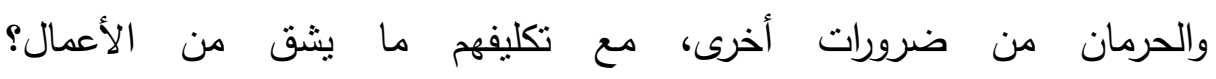

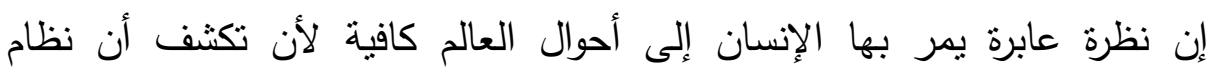

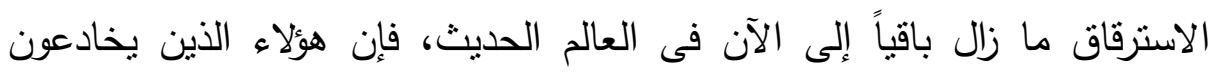

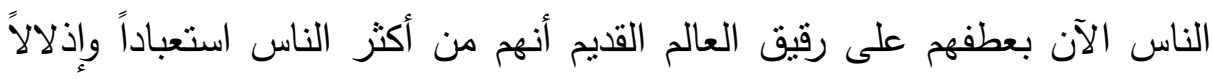

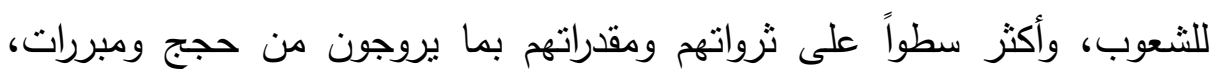

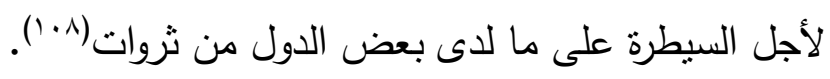

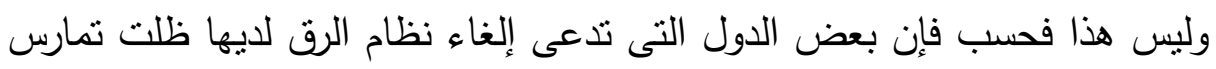

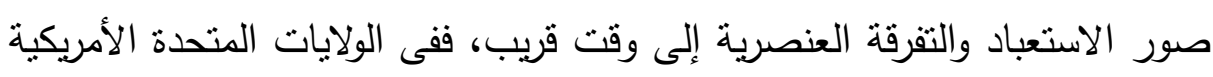

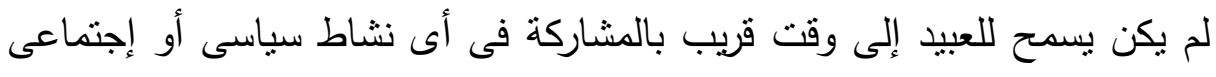
إلى أن حدث خلاف بين الجنوبيين

(منهج الإسلام فى القضاء على الرق...) د. صفية محمد محمد سرحان 
والثماليين حول عملية التصويت فى الانتخابات، فقد كان الثماليون يفوزون دائما فى الانتخابات، وذلك لأن معظم سكان الجنوب كانوا من الرقيق الذين لم يكن لهم

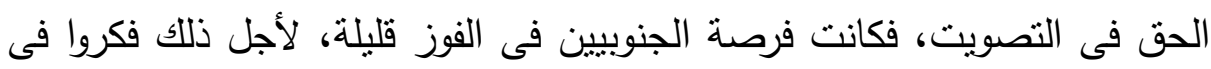

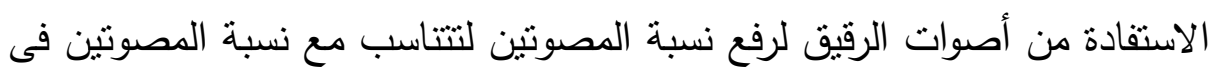

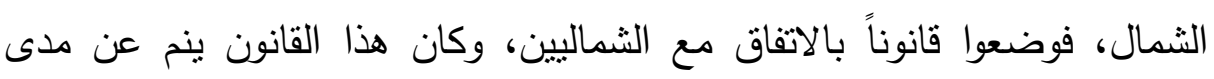
الاحتقار والدونية التى كان يتعامل بها الرقيق فى هذا المجتمع، حيث سمى القانون

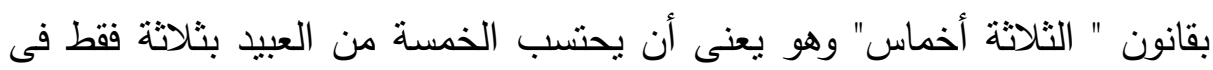

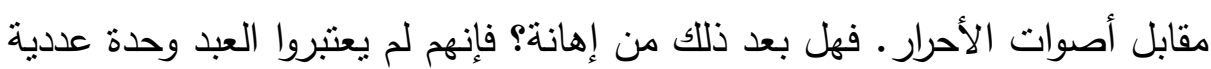

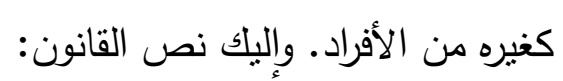

"The issue of how to count slaves split the delegates into two groups. The northerners regarded slaves as property who should receive no representation. Southerners demanded that Blacks be counted with whites. The compromise clearly reflected the strength of the proslavery forces at the convention. The "Three-fifths Compromise" allowed a state to count three fifths of each Black person in determining political representation in the House."

Historic U.S. Cases

$1690-1993$

ISBN 0-8240-4430-4

The three-fifths cause remained in force until the post-Civil War 13th Amendment freed all enslaved people in the United States, the 14th amendment gave them full citizenship, and the 15th Amendment granted black men the right to vote.

Sources:

David Waldstreicher, Slavery's Constitution: From Revolution to Ratification (New York: Hill and Wang, 2007)

ترجمته:

شكلت قضية كيفية حساب العبيد إنقسام بين النواب إلى مجموعتين، فاعتبر الثماليون العبيد ممتلكات لا يحق لهم تلقى أى تمثيل برلمانى، وطلب الجنوبيون

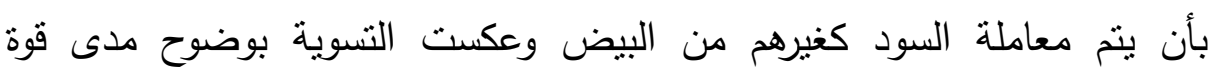
المجموعة المؤيدة للعبودية خلا الاجتماع، وقد سمحت اتفاقية " الثلاث أخماس " لئل

$$
\text { (منهج الإسلام فى القضاء على الرق...) د. صفية محمد محمد سرحان } 10
$$


للولاية بأن تحسب ثلاثة أخماس من كل شخص أسود لتحديد التثثيل السياسى فى

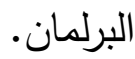
ظلت المادة التى نصت على اتفاقية " الثلاث أخماس " سارية حتى قامت الحرب الأهلية، ونص التعديل الثالث عشر على تحرير جميع العبيد فى الولايات المتحدة

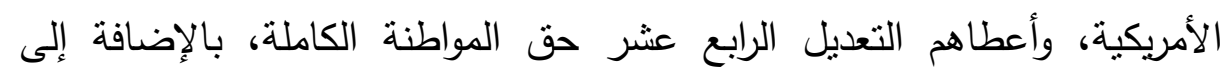
ضمان التعديل الخامس عشر حق التصويت للرجال السود أ.هـ. علما بأن هذه الاتفاقية صدرت سنة VAv وظلت سارية حتى قامت العرب العرب الأهلية

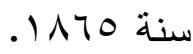
وأعنى بذللك أن الاستعباد ظل موجوداً فى أكثر الدول التى تدعى الددنية

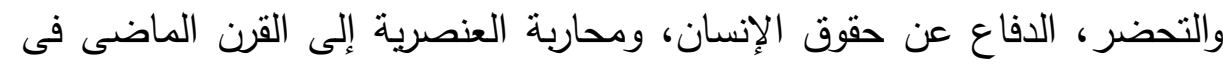

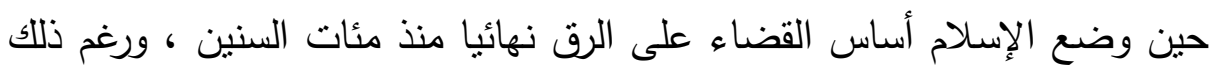

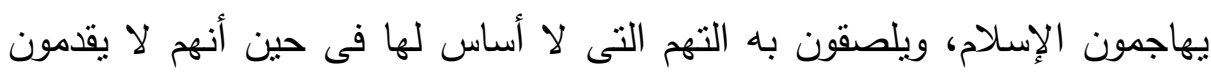

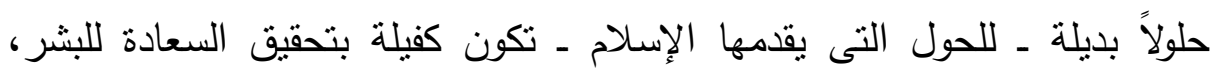

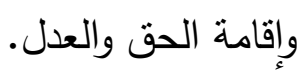

$$
\text { (منهج الإسلام فى القضاء على الرق...) د. صفية محمد محمد سرحان }
$$




\section{الخاتمة}

الحمد لله على جميل نعمه، وعظيم مدده وكرمه، الحمد لله على عونه وسنده، أحمده سبحانه وتعالى حمدا لايحد ولا ينتهى أن أمدنى بعونه ، وأسبل على ستره وكميه ، وبيسر

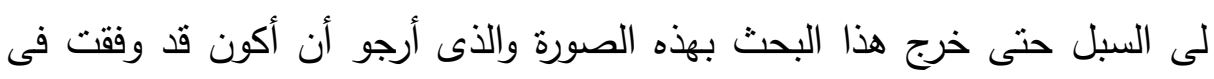
عرضله بصورة لائقة، وأن يرزقنى فيه القبول، وأن يكون خالصا لوجه الله تعالى.

$$
\text { وبعد: }
$$

نسطيع أن نستخلص الآتى:

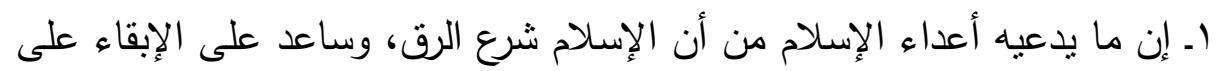

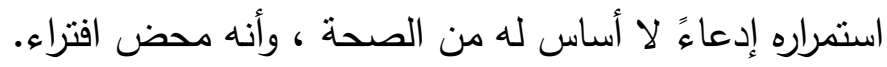

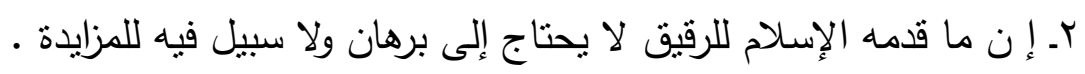

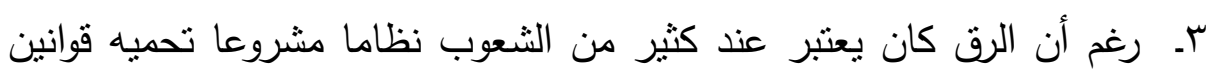
الدولة، إلا أن الإسلام وضع الحلول للقضان لـاء عليه.

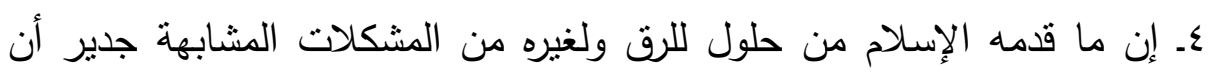
يدون فى كتب النظم الدولية ؛ ليسير على خطاه المشرعون وصناع القرار فى جميع الإنى

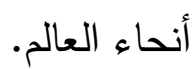

وفى النهاية نسطيع أن نقول: إن أعداء الإسلام مهما حاولوا للطعن فيه واختلاق

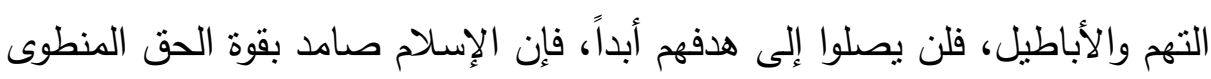

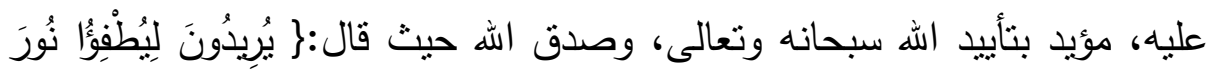

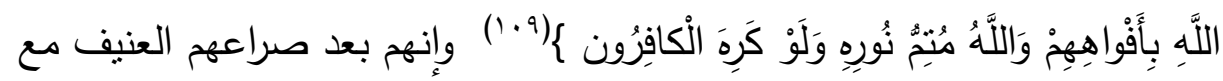

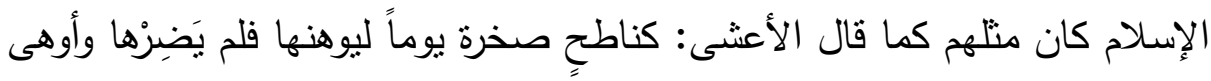

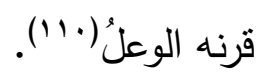

(منهج الإسلام فى القضاء على الرق...) د. صفية محمد محمد سرحان 
فالإسلام لم يشرع الرق كما شرعته الأمم الأخرى بل شرع العتق ورغب فيه وييقى

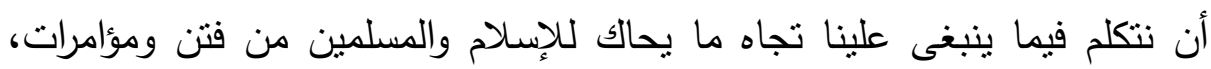

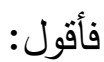

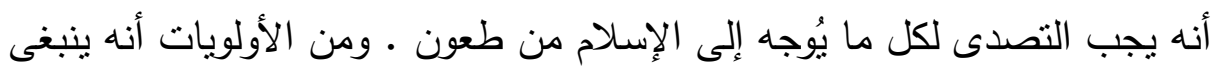

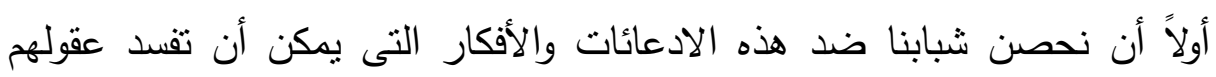

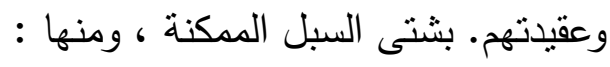

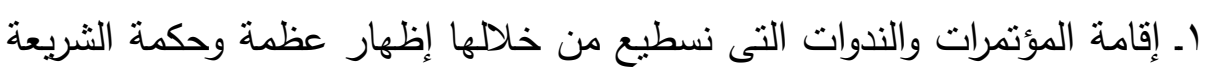
الإسلامية فى حلول مشكلات العالم القديم والمعاصر.

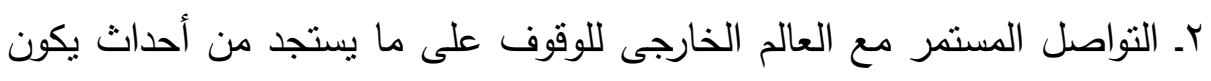

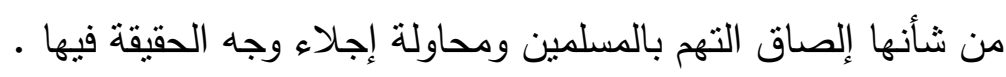

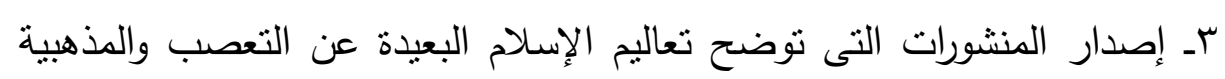

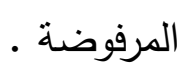

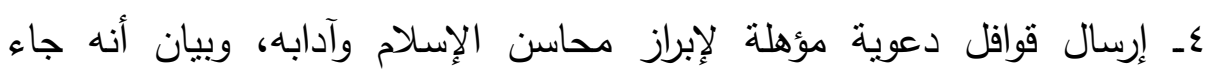
لإصلاح حياة البشر ، وتتقية المجتمعات من المساوئ الأخلاقية والإجتماعية.

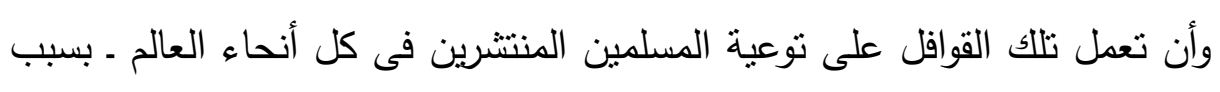

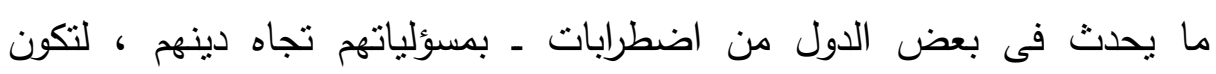

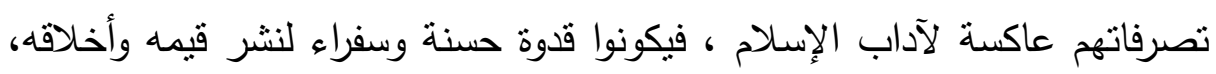

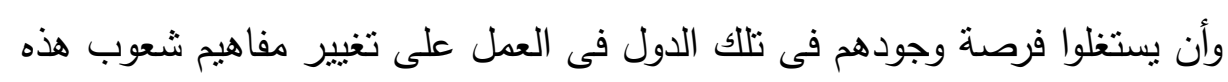

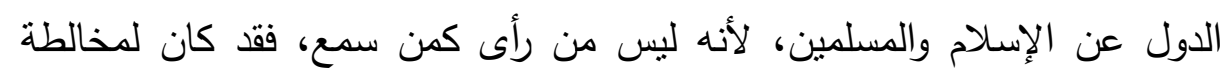

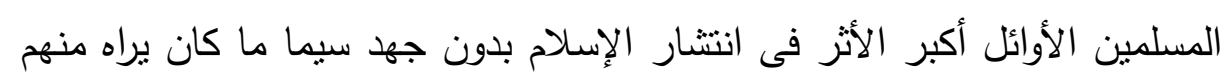

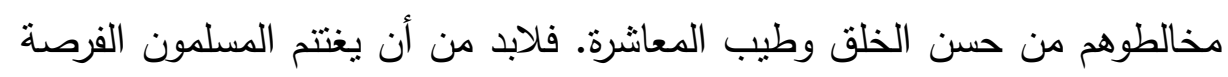

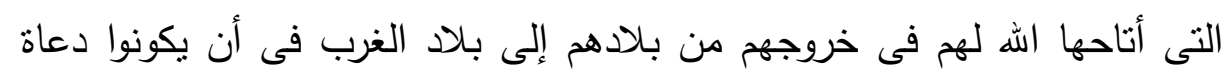

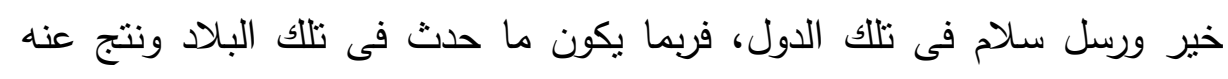

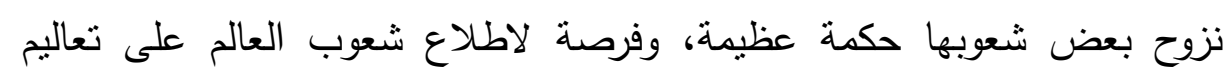

$$
\text { (منهج الإسلام فى القضاء على الرق...) د. صفية محمد محمد سرحان }
$$


الإسلام، فالفرص ليست بالضرورة تكمن فى العطايا، بل أحياناً تكون الفرصة

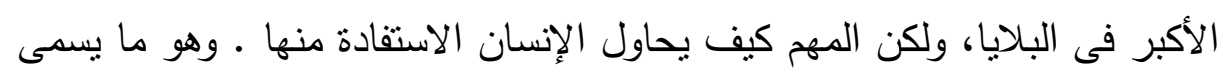

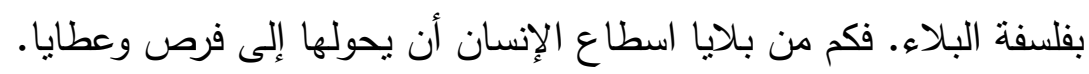
وفى الختام أسأل اله عز وجل أن أكون قد وفقت فيما اجتهدت، وأن يتجاوز عما قد

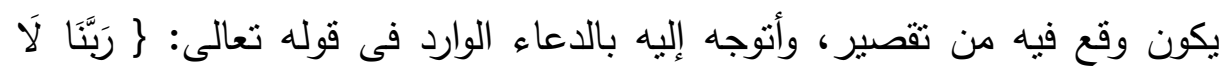

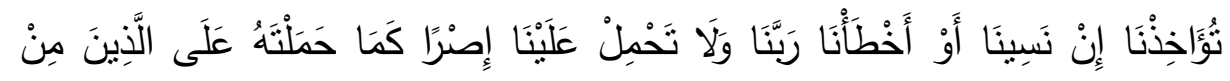

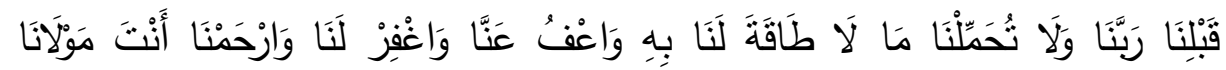

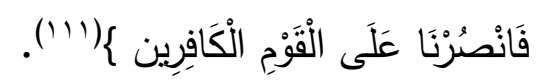




\section{الكوامش}

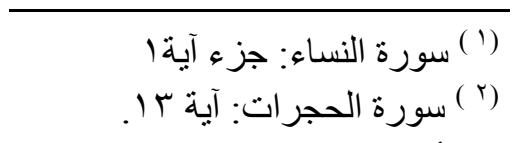

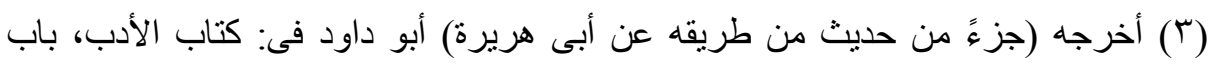

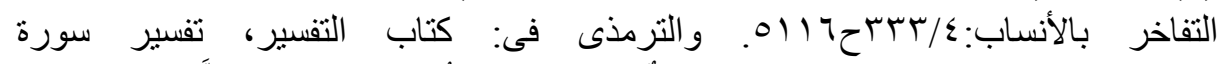

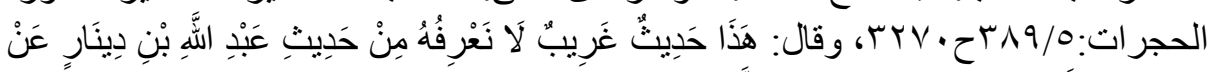

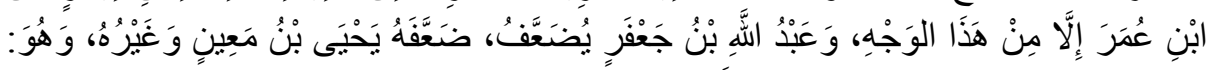

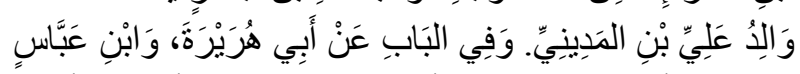

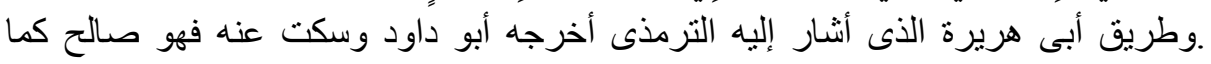

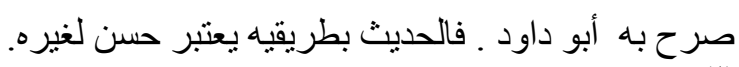

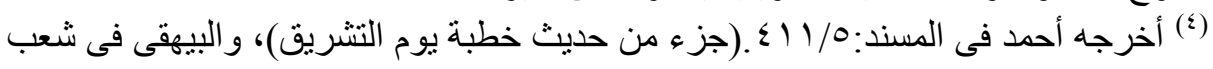

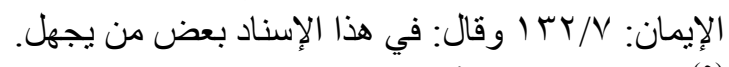

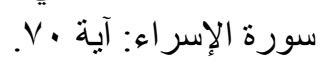

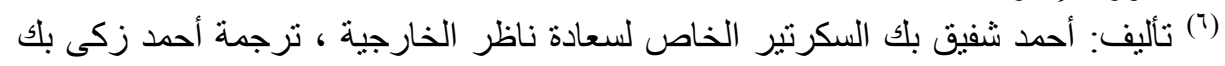

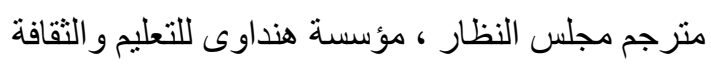
(V)

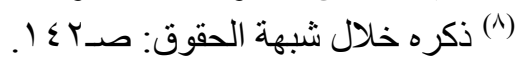

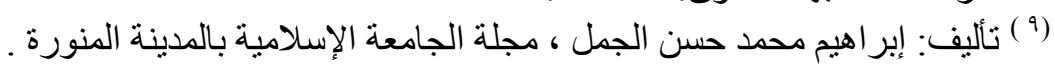

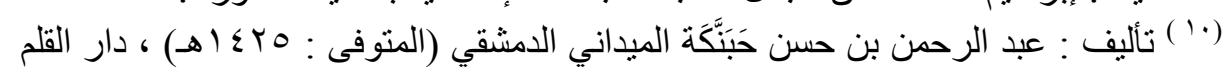

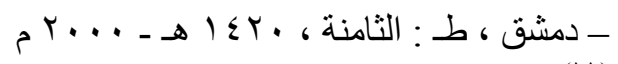

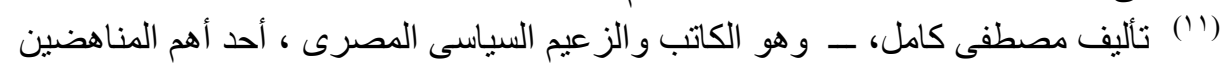

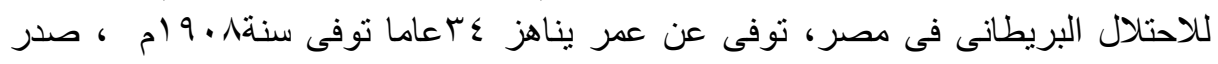

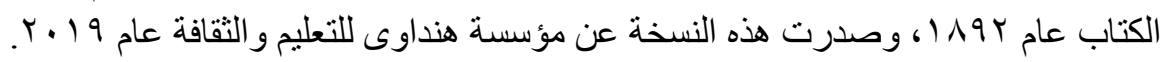

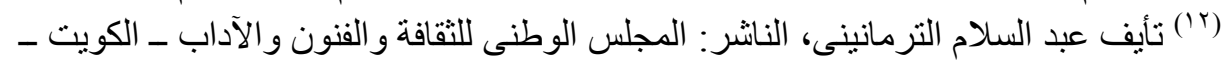

$$
\begin{aligned}
& \text {. } 9 \vee 9
\end{aligned}
$$

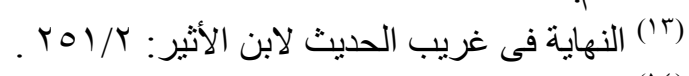

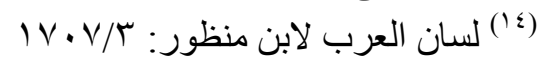

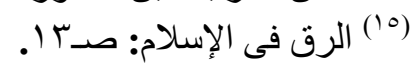

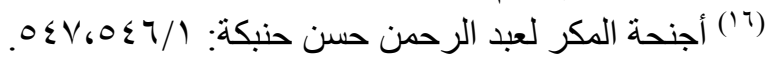

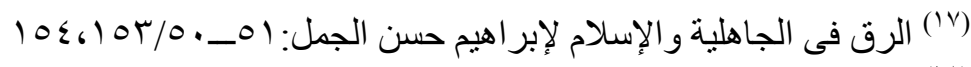

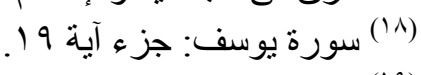

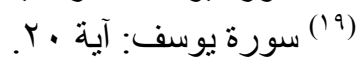

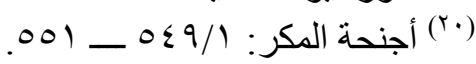

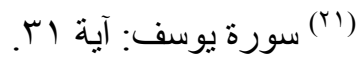

$$
\begin{aligned}
& \text { (منهج الإسلام فى القضاء على الرق...) د. صفية محمد محمد سرحان } \\
& \text { I. } r \text {. }
\end{aligned}
$$




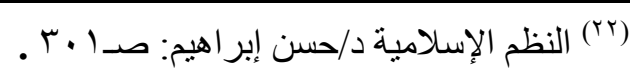

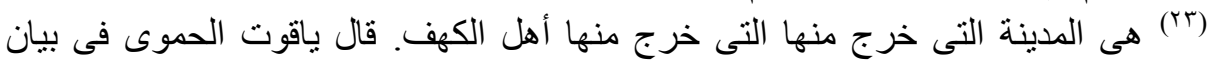

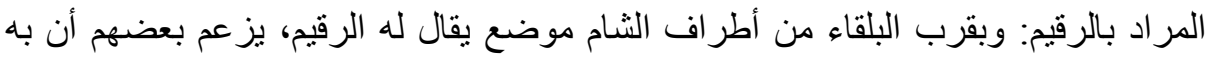

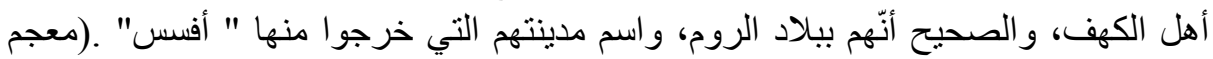

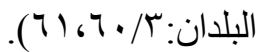

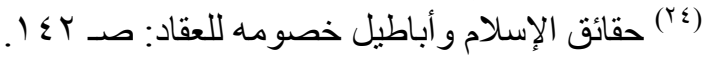

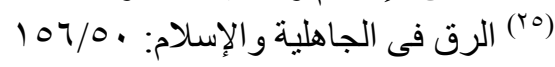

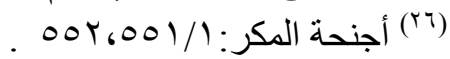

(YV)

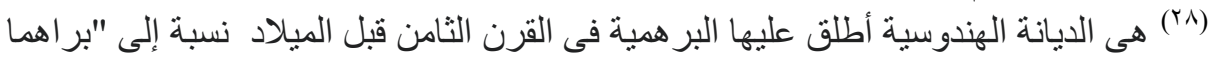

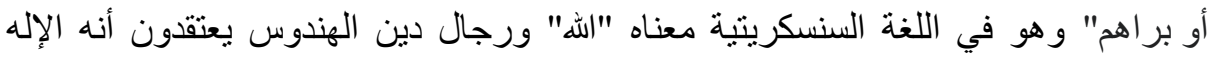

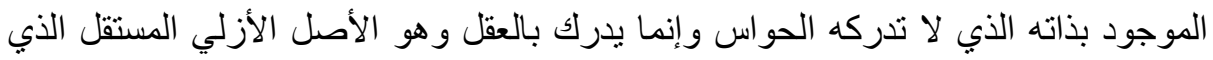

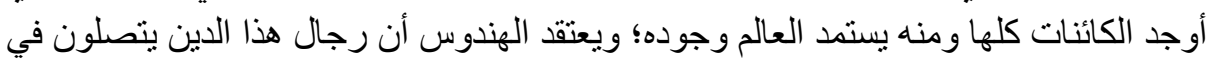

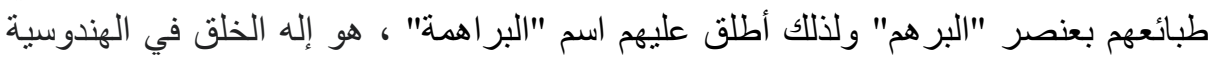

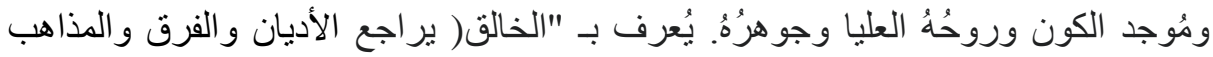

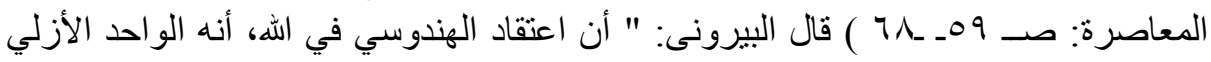

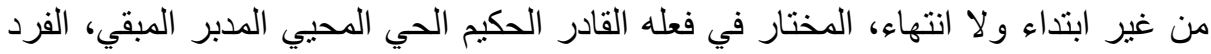

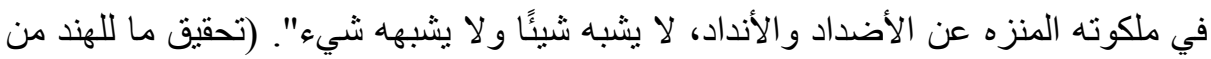

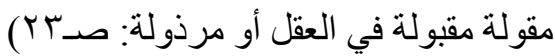

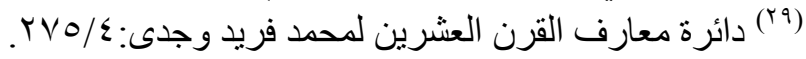

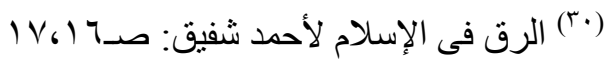

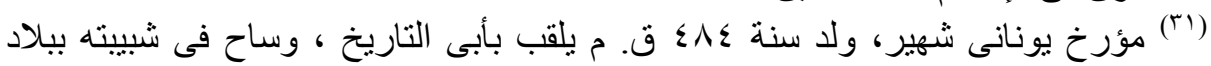

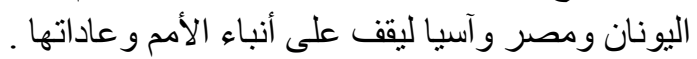

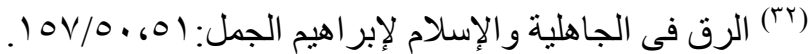

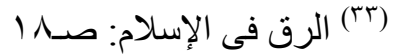

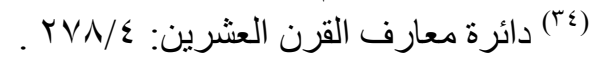

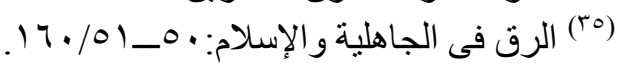

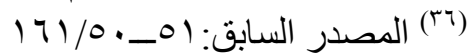

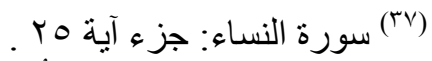

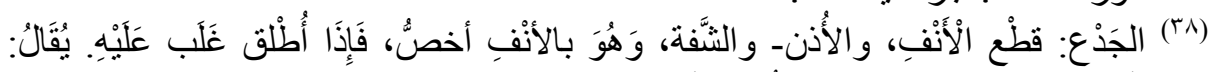

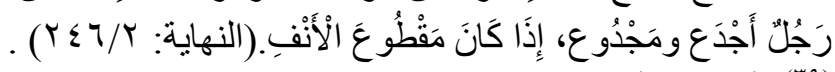

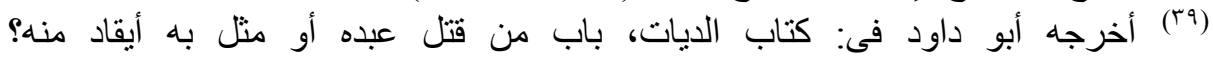

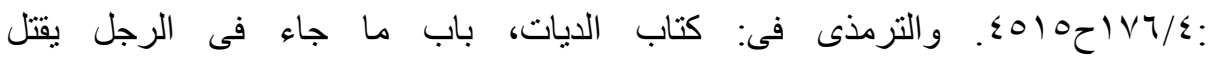

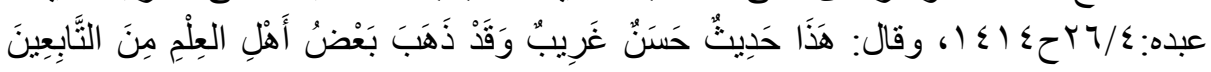

(منهج الإسلام فى القضاء على الرق...) د. صفية محمد محمد سرحان 


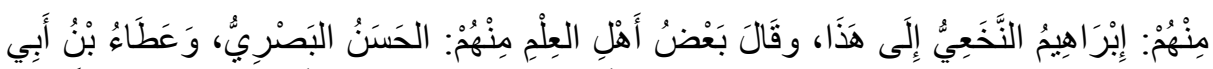

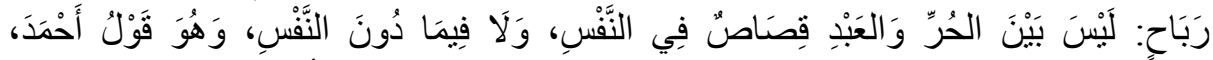

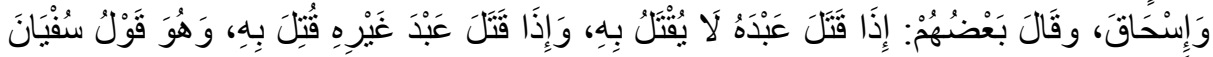

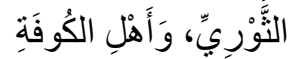

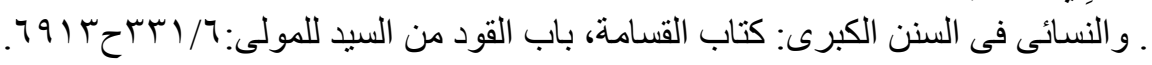

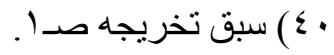

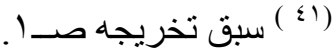

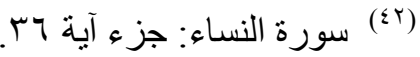

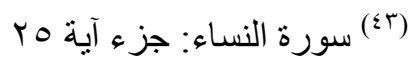

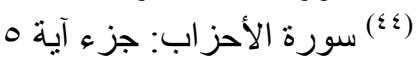

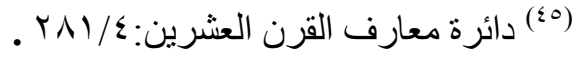

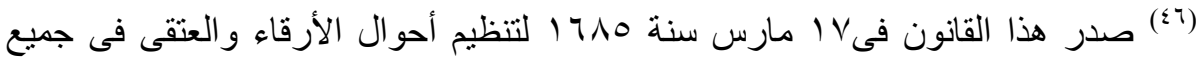

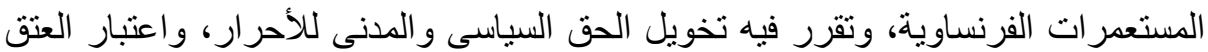

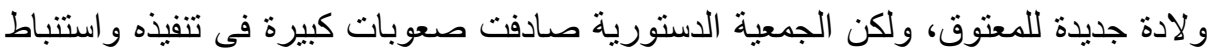

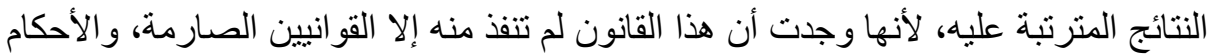
البالغة الثدة فى حق الرقيق، أما الأصول التى تحصر سلطة التهانة الموالى، أو تحملهم حقوق

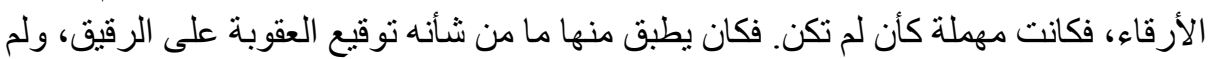

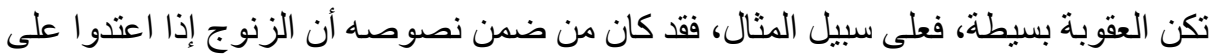

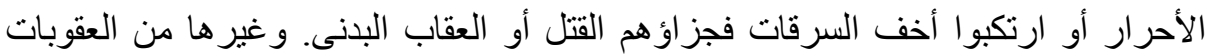

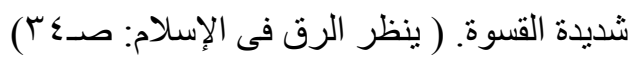

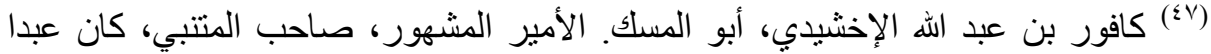

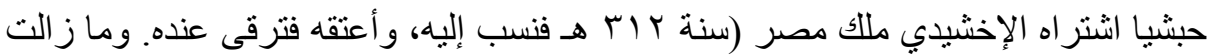

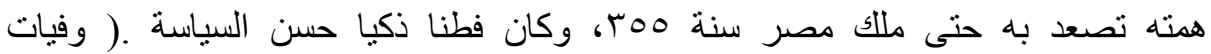

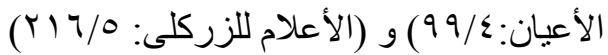
(\&A)

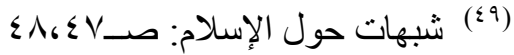

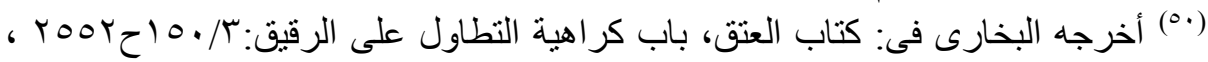

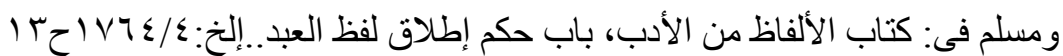

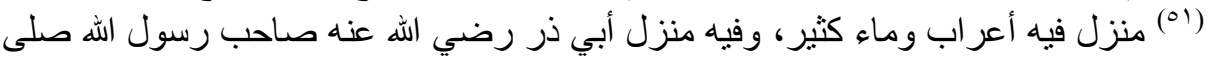
الله عليه وسلم وفيه قبره وفيها مسجد جامع، و هي من القرى القديمة في الجاهلية.

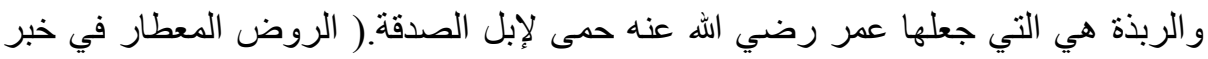

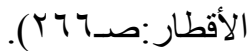

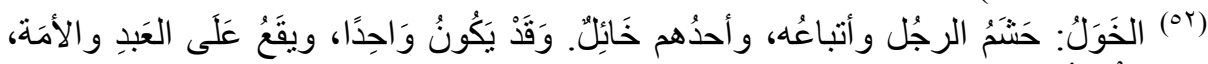

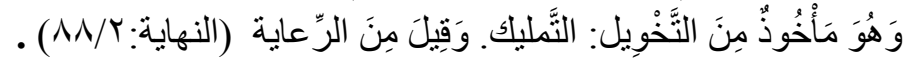

(منهج الإسلام فى القضاء على الرق...) د. صفية محمد محمد سرحان 


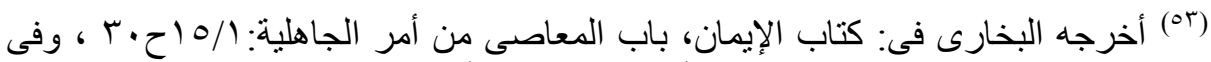

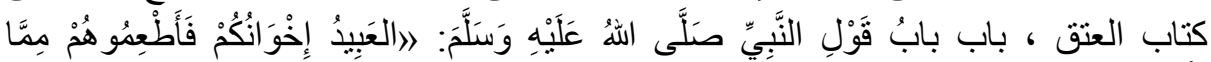

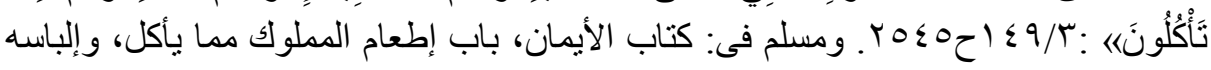

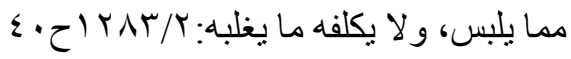

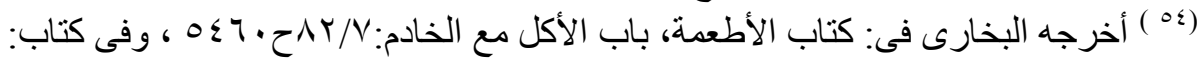

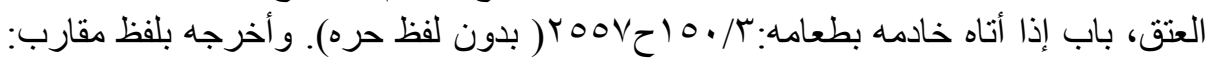

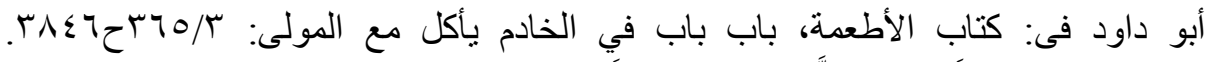

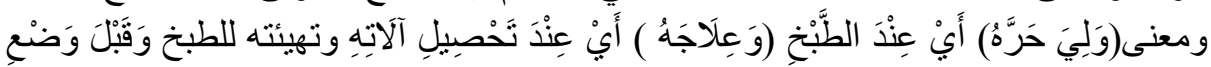

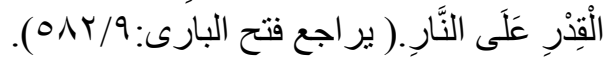

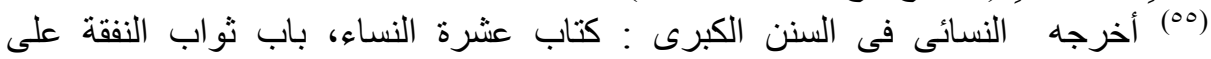

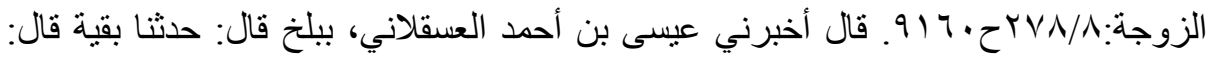

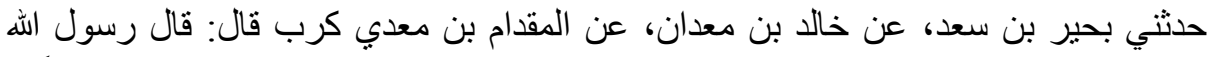

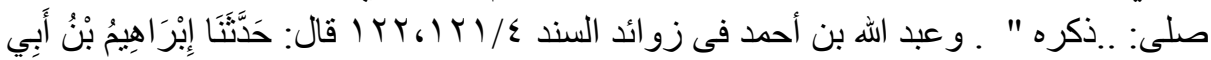

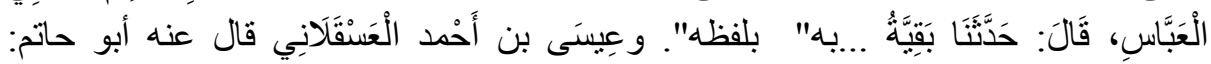

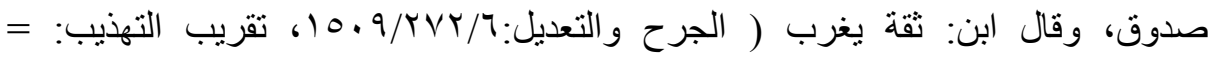

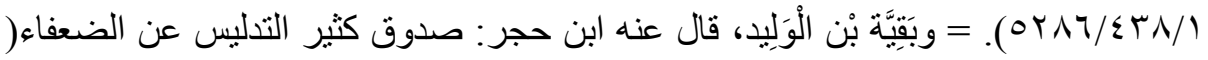

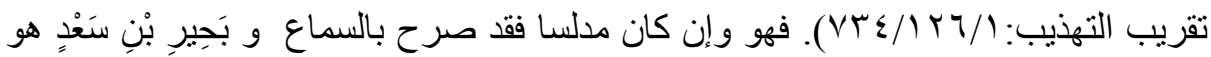

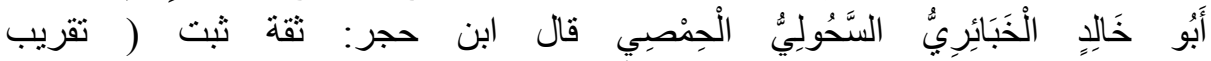

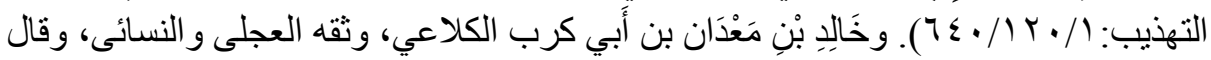

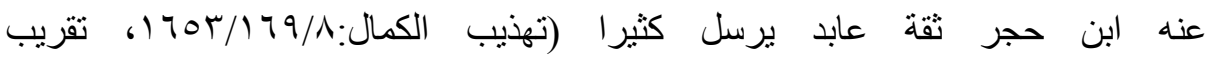

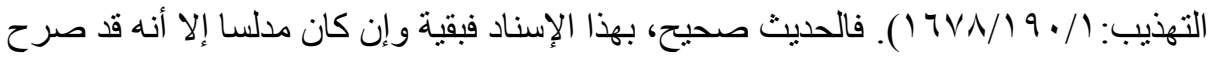
بالسماع، وبقية رجال الإسناد ثقات كما هو واضتح من نرجمتهم.

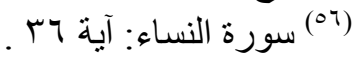

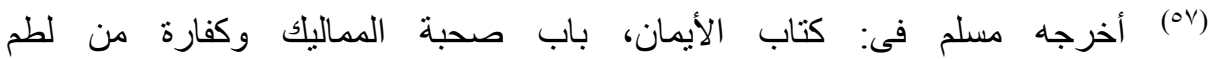

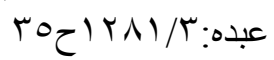

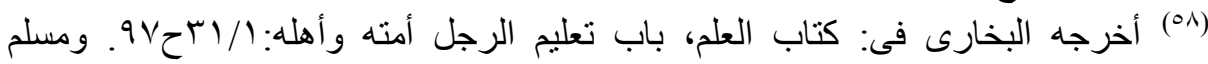

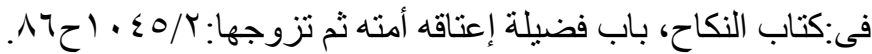

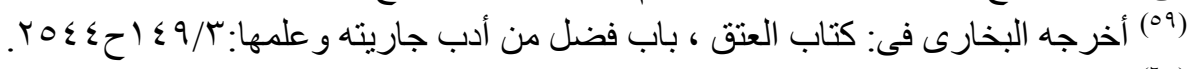

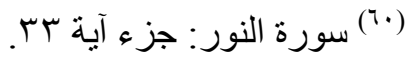

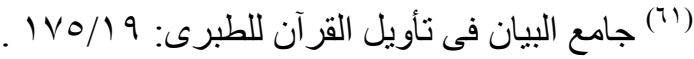

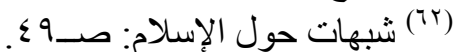

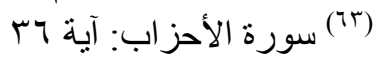

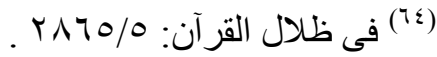

$$
\begin{aligned}
& \text { (70) أي أدو ا حقوقهم وحسن ملكتهم. }
\end{aligned}
$$

$$
\text { (منهج الإسلام فى القضاء على الرق...) د. صفية محمد محمد سرحان }
$$


(ب7) حتى ما يفيض بها لسانه: أي ما يجري بهذه الكلمة لسانه (شرح محمد فؤاد عبد الباقى لسنن ابن ماجه). و الحديث أخرجه النسائى فى السنن الكبرى: كتاب وفاة النبى صلى صلى الله عليه

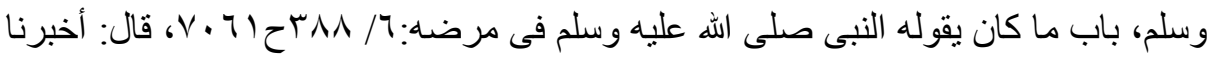

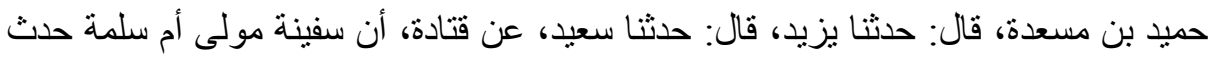

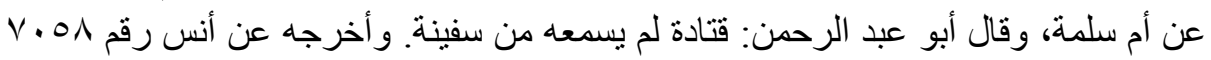

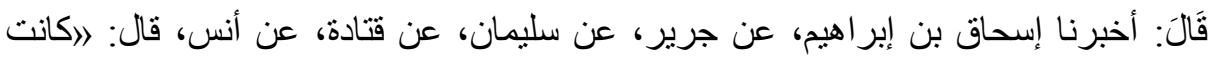

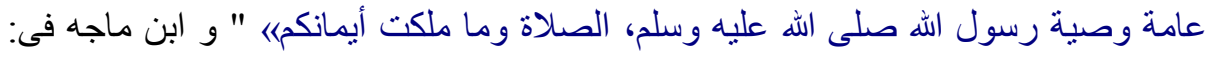

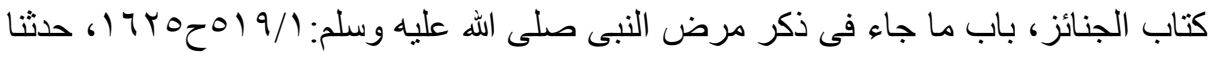

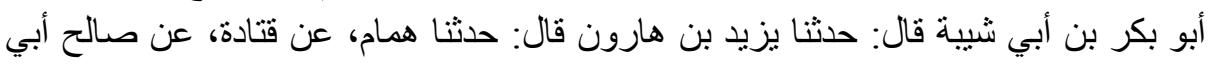

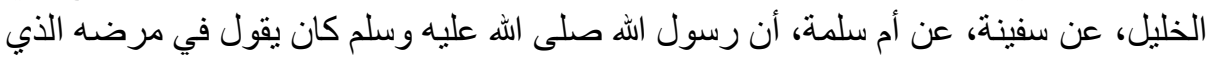

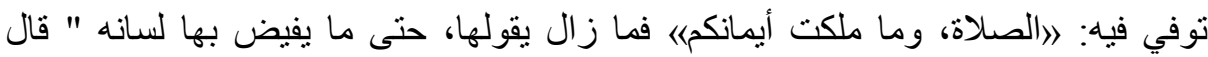

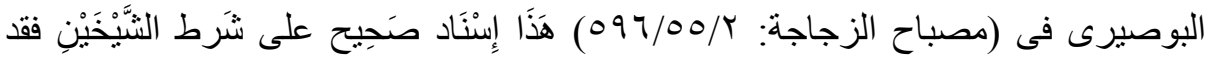

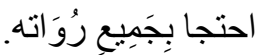

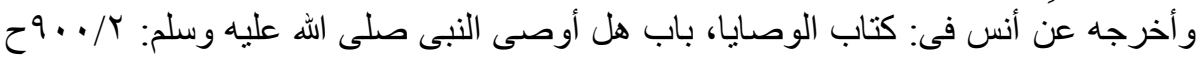
و T9V قتادة، عن أنس بن مالك قال: كانت عامة وصية رسول الله صلى الله عليه وسلم حين حضرته

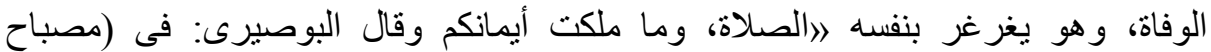

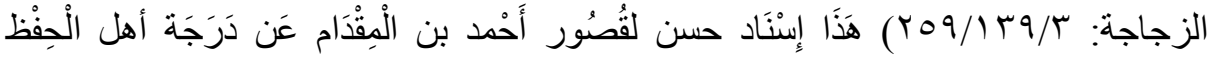

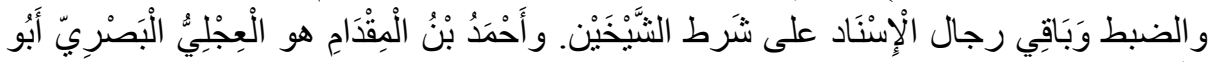

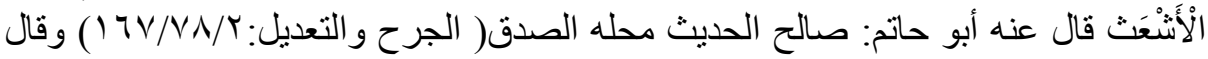

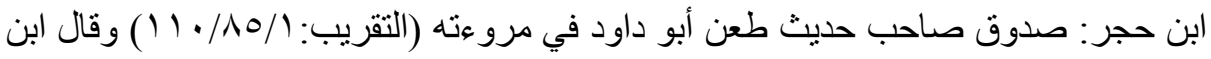

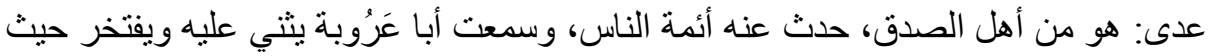

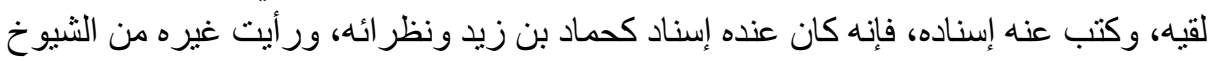

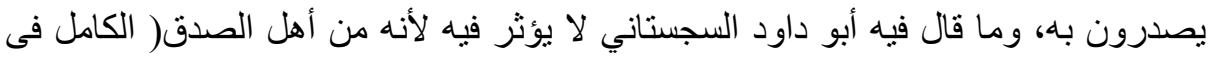

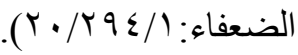

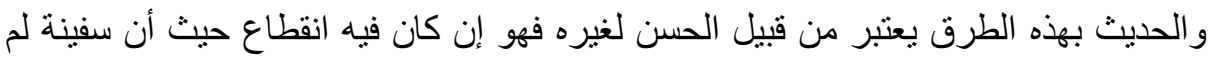

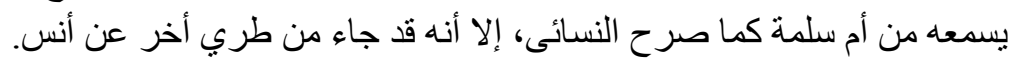

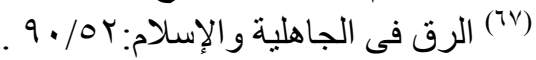

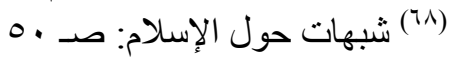

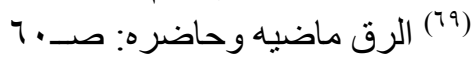

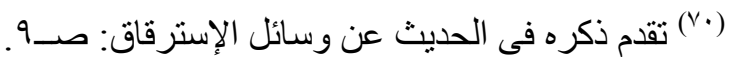

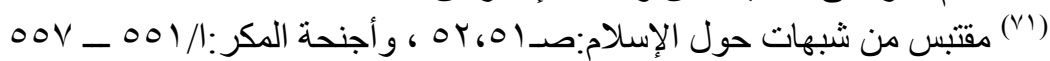

(منهج الإسلام فى القضاء على الرق...) د. صفية محمد محمد سرحان 


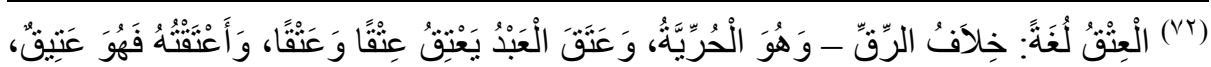

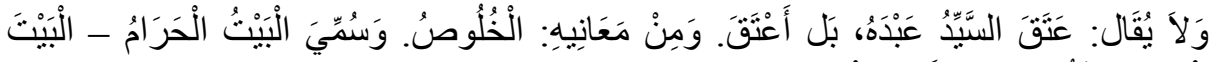

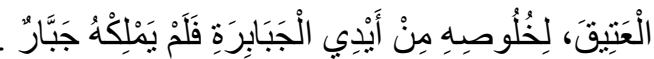

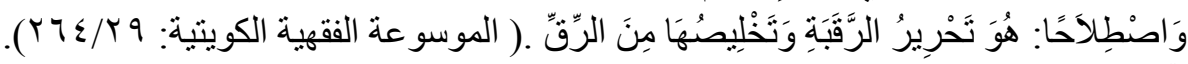

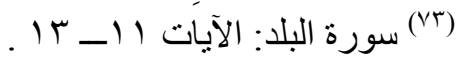

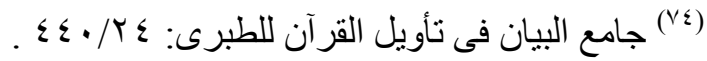

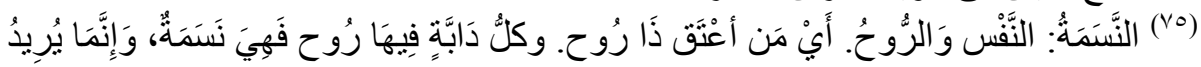

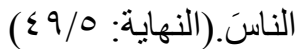

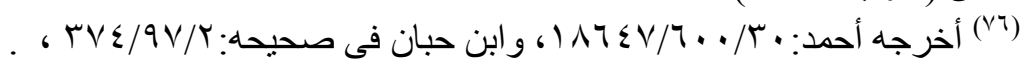
(Yv)

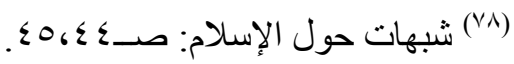

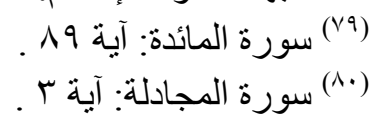

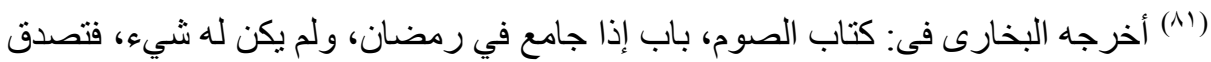

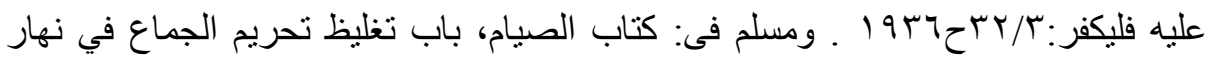

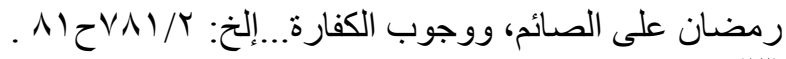

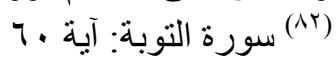

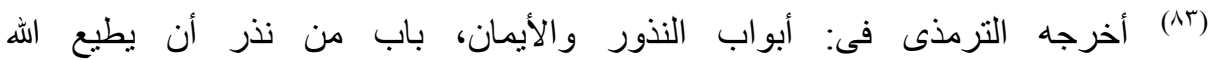

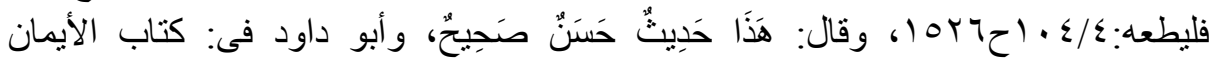

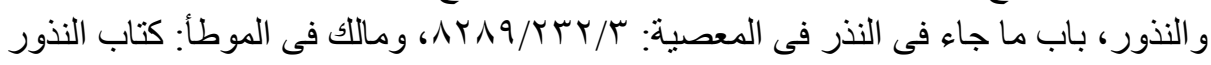

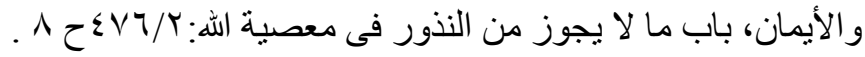

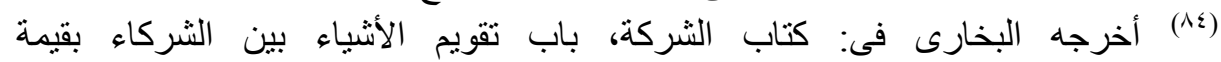

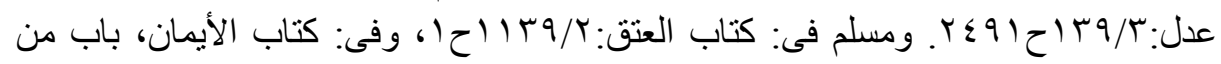

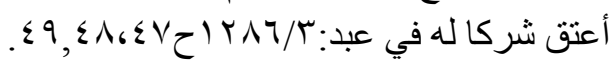

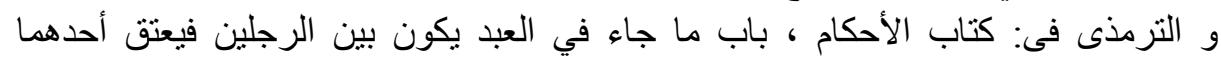

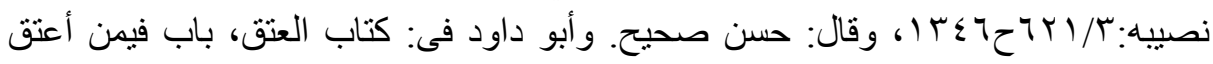

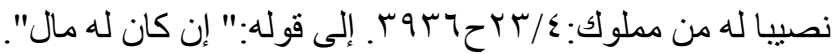

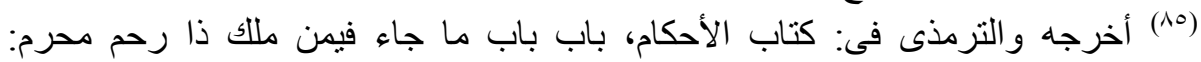

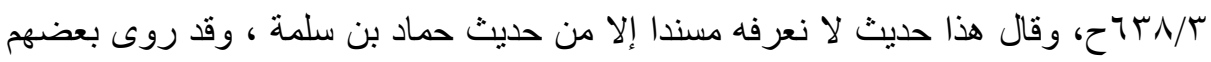

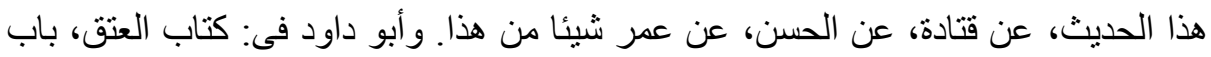

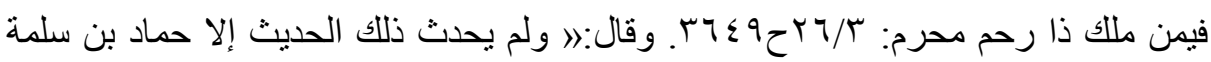

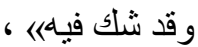

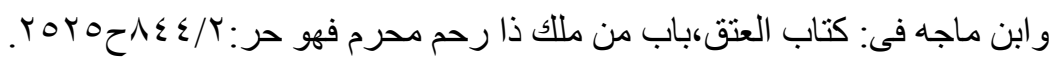

(منهج الإسلام فى القضاء على الرق...) د. صفية محمد محمد سرحان 


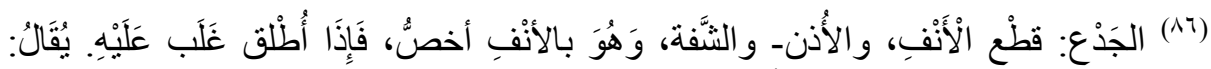

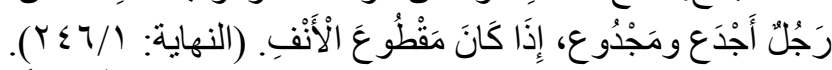
أخرجه أحمد: (AV)

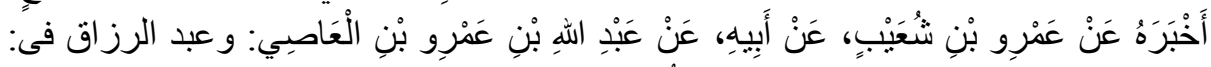

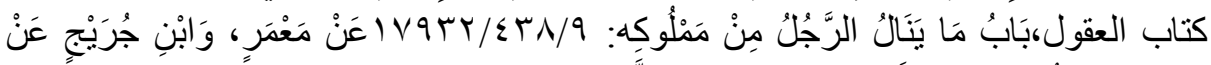

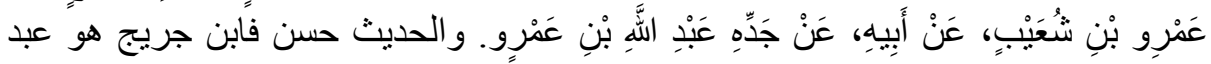

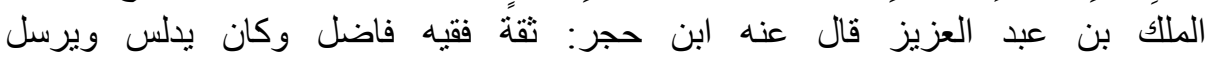

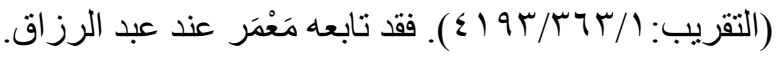

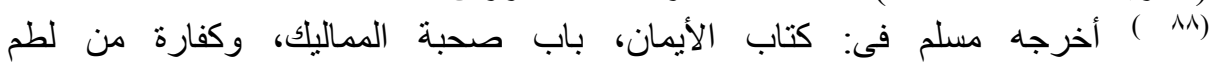

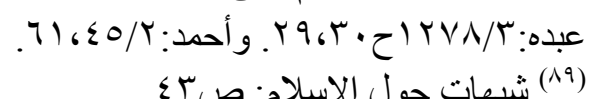

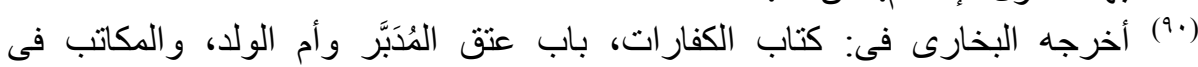

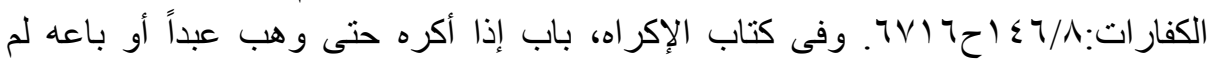

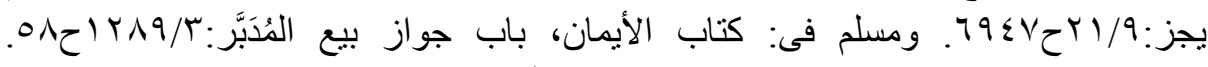

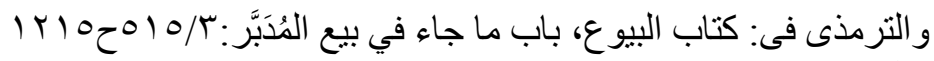

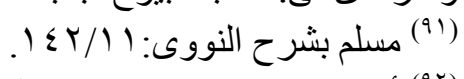

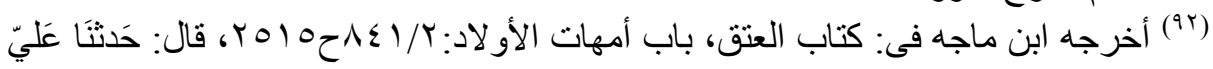

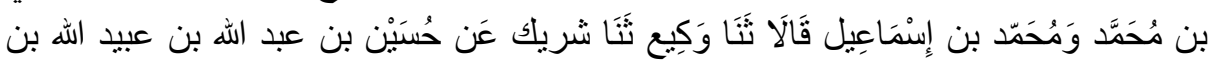

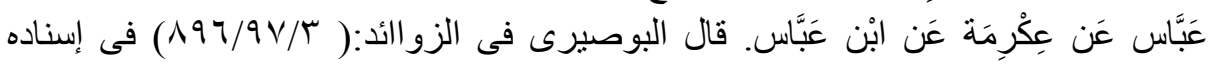

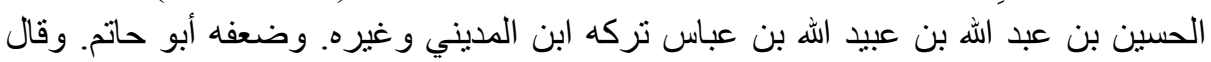
البخاري إنه كان يتهم بالزندقة. (9r)

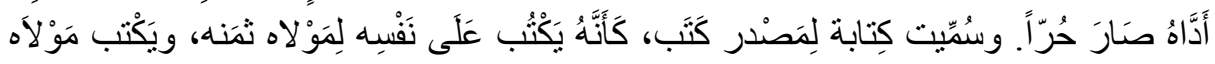

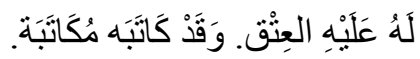

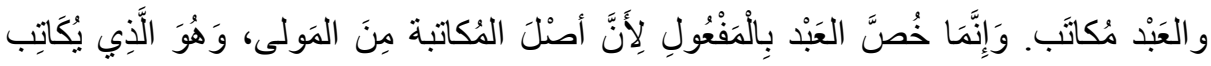

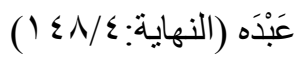

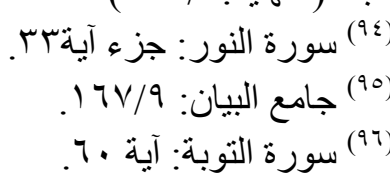

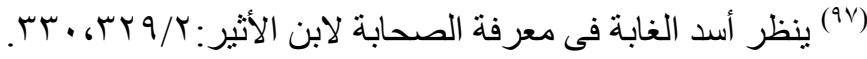

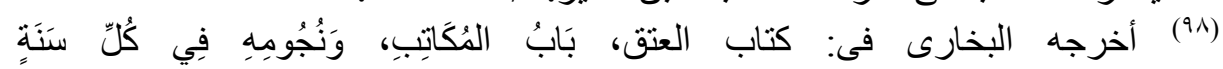

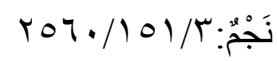
(99) أى قضى النبى صلى الله عليه وسلم ثلاث قضايا.

$$
\text { (منهج الإسلام فى القضاء على الرق...) د. صفية محمد محمد سرحان }
$$


(') أى خيرها النبى صلى الله عليه وسلم بين أن تبقى تحت زوجها العبد وبين أن تفسخ

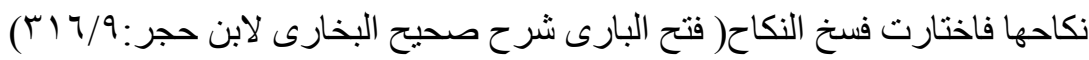

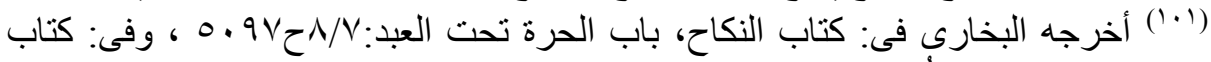

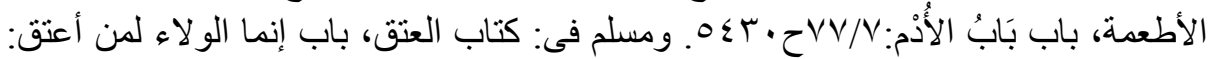
. $1 \leqslant ح \leqslant \varepsilon / 4$

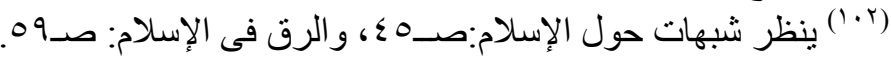

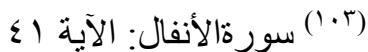

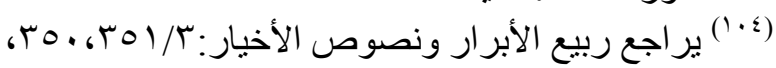
(1.0)

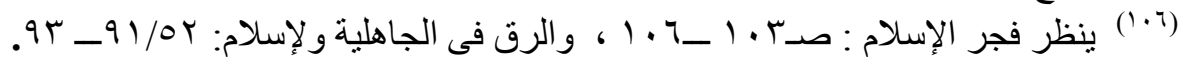

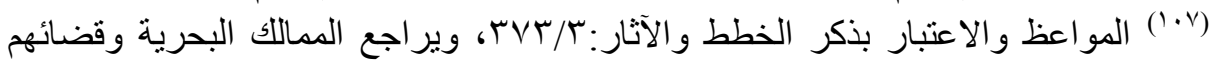

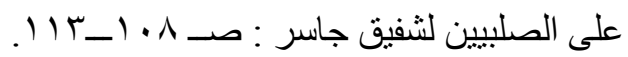
0

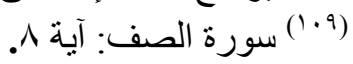

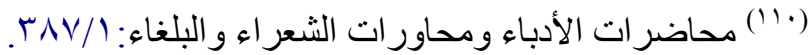

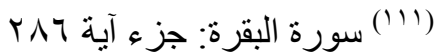




\section{المراجـع}

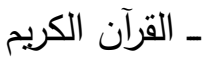

ـ أجنحة المكر الثلاثة وخوافيها ـ عبد الرحمن بن حسن حَبَنَكة الميداني الدمشقي -

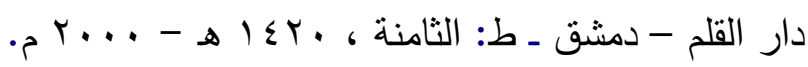

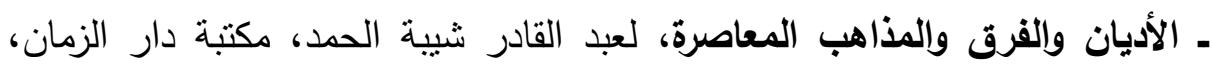

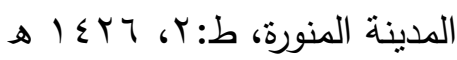
ـ أسد الغابة فى معرفة الصحابة ـ لعز الدين بن الأثثر ـ دار إحباء التراث العربى ـ بيروت ـ لبنان ـ بدون طبعة وتاريخ.

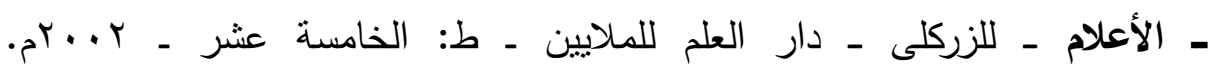
تحقيق ما للهند من مقولة مقبولة في العقل أو مرذولة ـ لأبى الريحان محمد بن

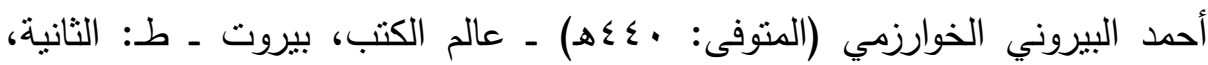
هـ

ـ التعريفات ـ لعلي بن محمد بن علي الزين الثريف الجرجاني (المتوفى: 17 الهـ) -

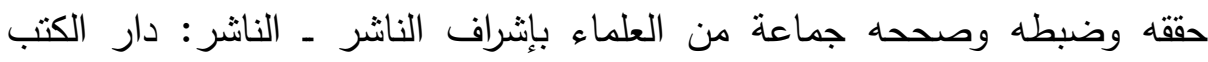

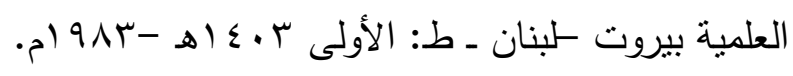

ـ تقريب التهذيب ـ لأبى الفضل أحمد بن علي بن محمد بن أحمد بن حجر العسقلاني

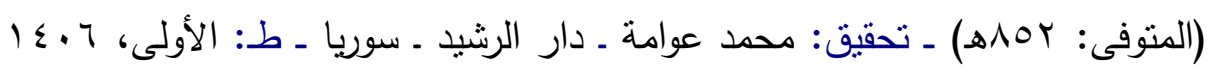

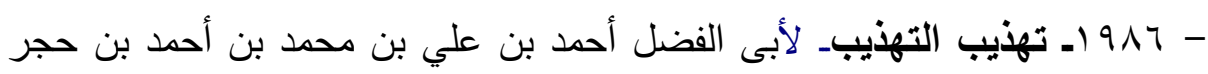

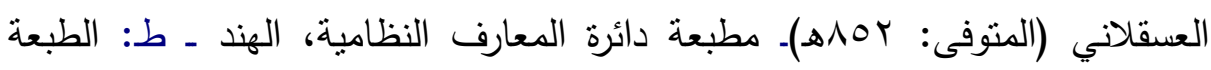

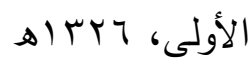

ـ تهذيب الكمال في أسماء الرجال ـ ليوسف بن عبد الرحمن بن يوسف، أبى الحجاج،

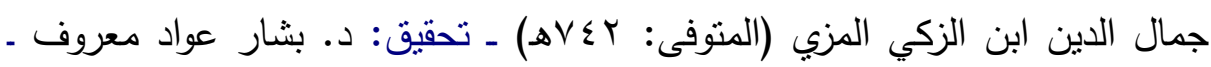

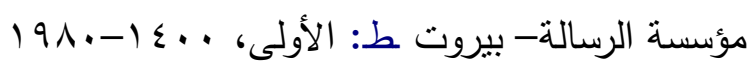

(منهج الإسلام فى القضاء على الرق...) د. صفية محمد محمد سرحان 
- جامع البيان في تأويل القرآن ـ لمحد بن جرير بن يزيد بن كثثر ، أبى جعفر

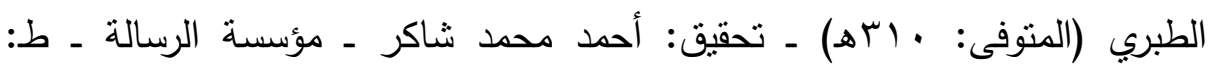

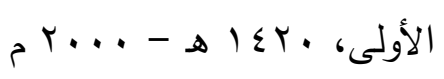

ـ حقائق الإسلام وأباطيل خصومها ـ عباس محمود العقاد ـ مؤسسة هنداوى للتعليم والثقافة. بدون طبعة وتاريخ. ـ دائرة معارف القرن العشرين ـ محمد فريد وجدى ـ دار الفكر - بيروت ـ بدون طبعة

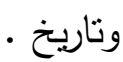
- ربيع الأبرار ونصوص الأخيار ـ لجار الله الزمخشري نوفي سماه هـ ـ مؤسسة

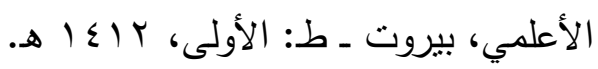

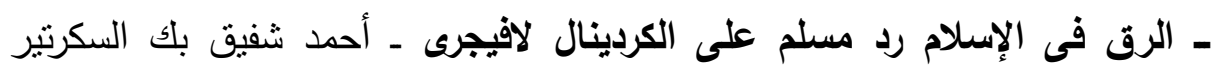

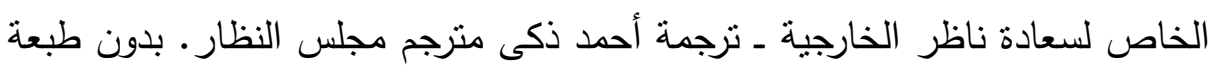
وتاريخ. ـ الرق في الجاهلية والإسلام - إبراهيم محمد حسن الجمل ـ مجلة الجامعة الإسلامية بالمدينة المنورة ورقم الجزء هو رقم العدد من المجلة. ـ الروض المعطار في خبر الأثطار- لأبى عبد الله محمد بن عبد الله بن عند عبد المنعم

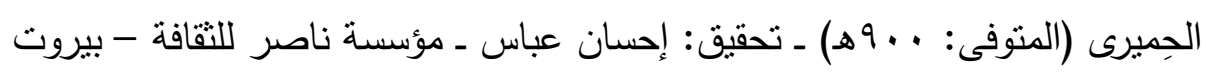

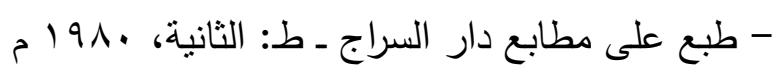

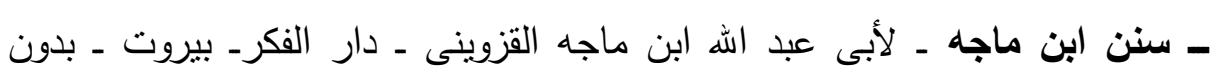
طبعة وتاريخ.

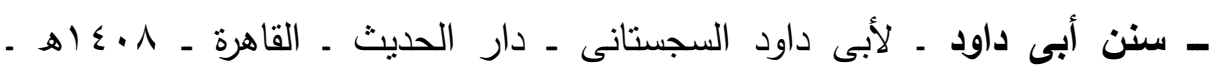
. $) 9 \wedge 1$

ـ سنن الترمذى - لأبى عبسى بن سورة التزمذى ـ تحقيق أحمد شاكر - مصطفى

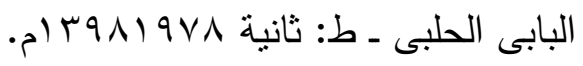
ـ السنن الكبرى - لأبى عبد الرحمن أحمد بن شعيب ، النسائي (المتوفى: ب. • آهـ) -

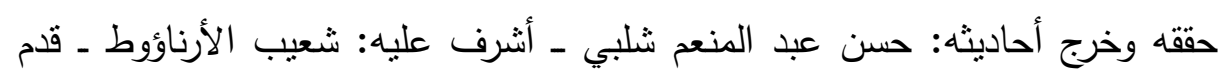

$$
\begin{aligned}
& \text { (منهج الإسلام فى القضاء على الرق...) د. صفية محمد محمد سرحان } \\
& \text { 1. } 9
\end{aligned}
$$


له: عبد الله بن عبد المحسن التركي ـ مؤسسة الرسالة - بيروت ط: أولى، ابك؟ ا هـ r...

ـ شبهات حول الإسلام ـ محمد قضب ـ دار الثروق. ط: الحادية والعشرون -

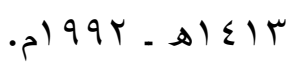

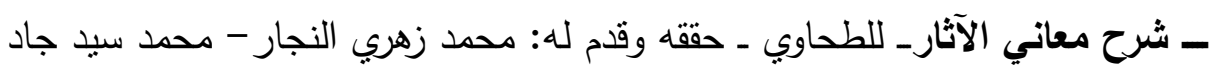

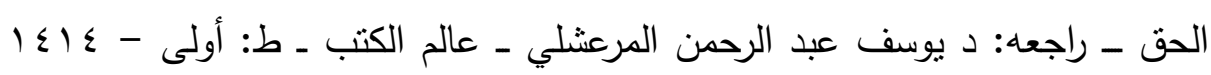
هـ 1998 ـ صحيح ابن حبان بترتيب ابن بلبان ـ لمحمد بن حبان بن أحمد بن حبان بن معاذ اذ

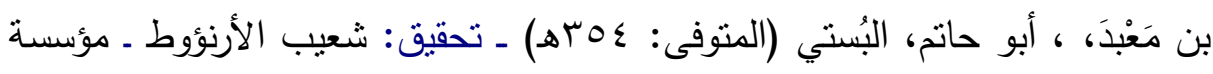

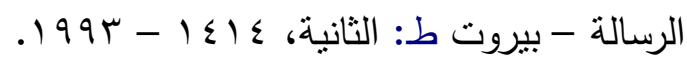
ـ صحيح البخاري ـ لمحمد بن إسماعيل أبو عبداله البخاري الجعفي ـ تحقيق: محمد زهير بن ناصر الناصر ـ دار طوق النجاة (مصورة عن السلطانية بإضافة ترقيم ترقيم

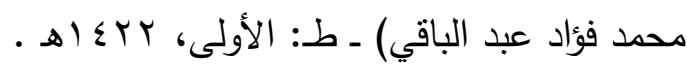

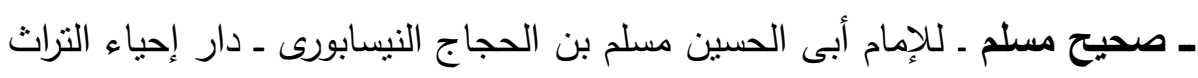

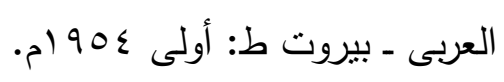
ـ صحيح مسلم بشرح النووى - أبو زكريا محي الدين يحيى بن شرف الند النوري

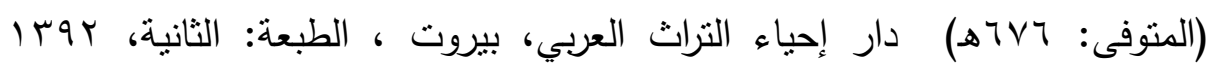

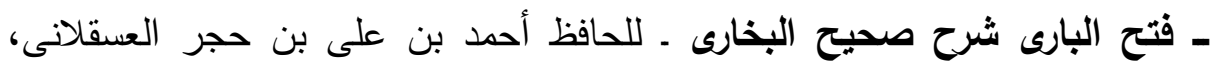

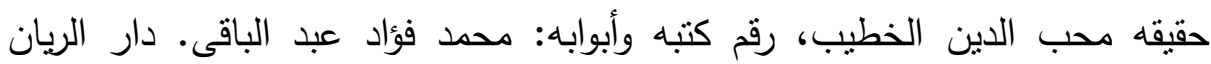

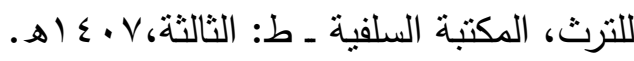

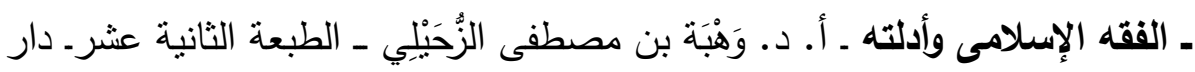

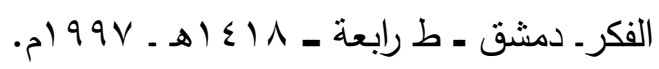
- فى ظلال القرآن - سيد قطب ـ دار الشروق - بيروت- القاهرة ـ ط: السابعة

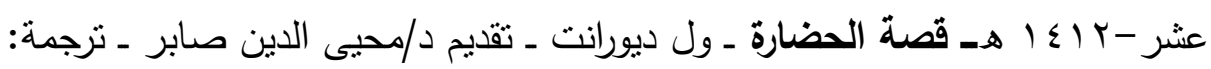

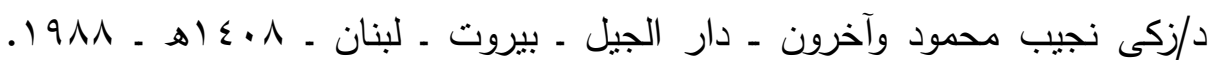

(منهج الإسلام فى القضاء على الرق...) د. صفية محمد محمد سرحان 
ـ الكامل في ضعفاء الرجال ـ لأبى أحمد بن عدي الجرجاني (المتوفى: 04سهـ) -

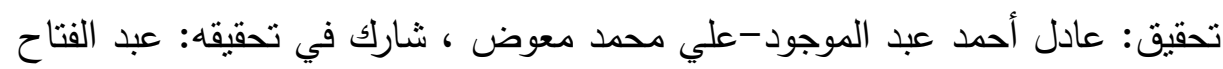

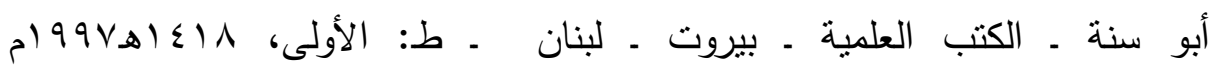
- لسان العرب - ابن منظور - دار المعارف - بدون طبعة وتاريخ.

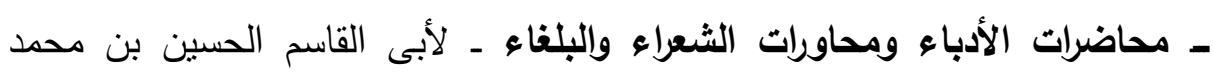
المعروف بالراغب الأصفهانى (المتوفى: Y.Oهـ) ـ شركة دار الأرقم بن أبي الأرقم -

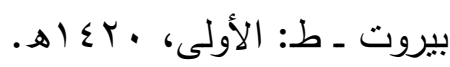

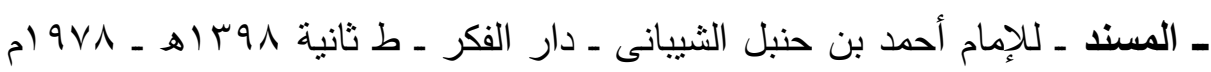

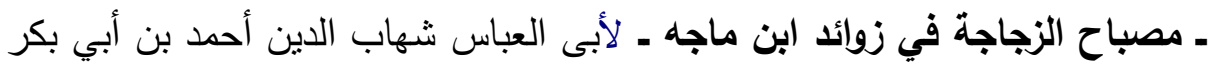

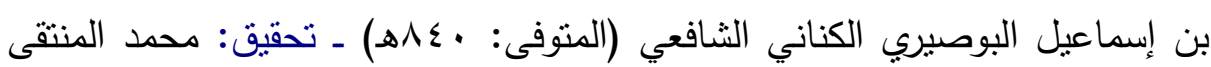

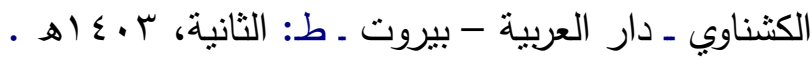

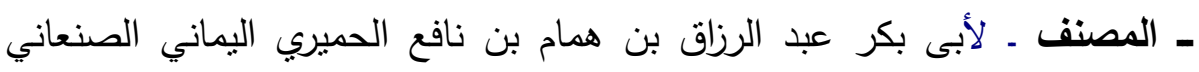

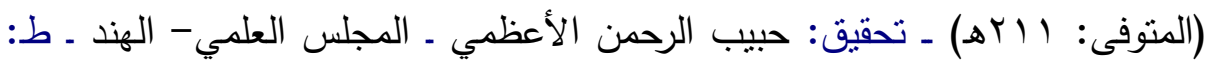

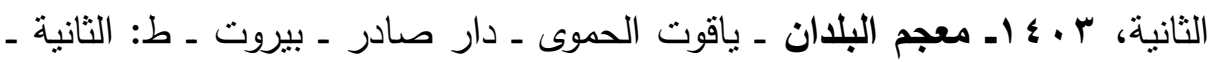
. 990 ـ المماليك البحرية وقضائهم على الصليبيين فى الثام ـ شفيق جاسر أحمد محمود ـ

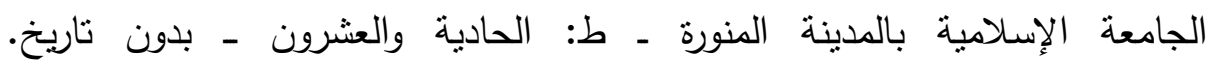
ـ منهج الشيخ عبد الرزلق عفيفي وجهوده في تقرير العقيدة والرد على المخالفين-

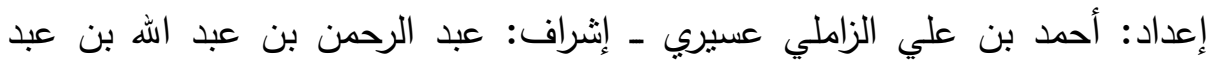

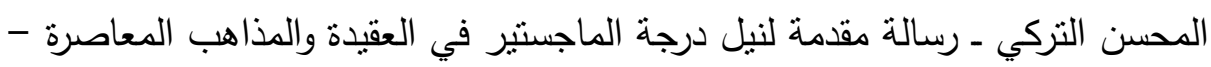
كلية أصول الدين - جامعة الإمام محمد بن سعود الإسلامية، المملكة العربية

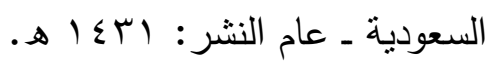

ـ المواعظ والاعتبار بذكر الخطط والآثار. لأحمد بن علي بن عبد القادر، أبى العباس

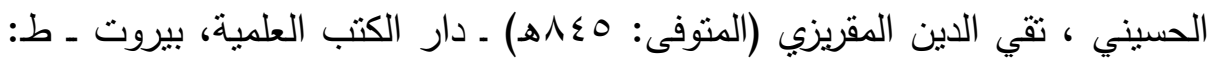

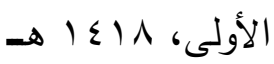

(منهج الإسلام فى القضاء على الرق...) د. صفية محمد محمد سرحان 
ـ الموسوعة الفقهية الكويتية ـ صادر عن: وزارة الأوقاف والثئون الإسلامية ـ

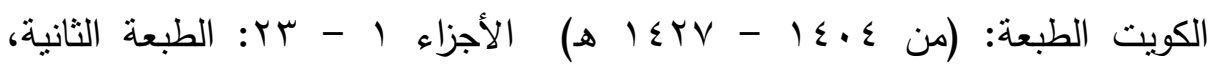

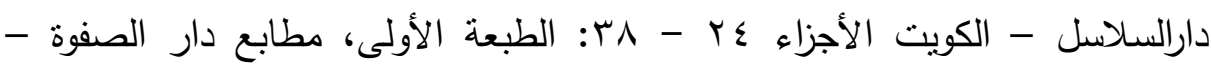

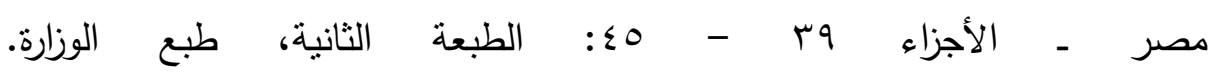

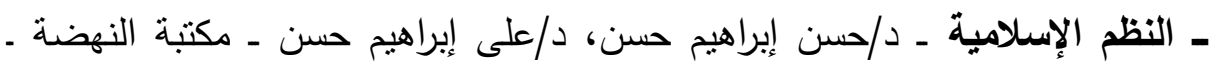
بدون طبعة وتاريخ. ـ النهاية فى غريب الحديث ـ لابن الأثير ـ تحقيق: طاهر أحمد الزاوى - محمود محمد الطناحي المكتبة العلمية - - بيروت - وفيات الأعيان - ابن خلكان - حققه: إحسان عباس ـ دار صادر بيروت ـ جزء $.19 \times 1-1 b / \varepsilon$ 


\section{Abstract}

This research, which is entitled "The Methodology of Islam in the Elimination of Slavery" is a presentation of the condition of slaves in all nations, and a comparison of that with its status in Islamic law. It's an evidence that Islam has established the principle of complete equality between Humans, and an explanation of the solutions Islam has provided to this phenomenon that promotes On the wisdom and greatness of Islam. In its development of solutions to such problems through the means it took to eliminate them. We see that when it went to solve the problem of slavery, it took into account all the circumstances surrounding it. Also, worked to develop solutions to it gradually, so as not to strike the interests of society in which this phenomenon was permeated.

\section{The importance of this study is: -}

1 - To dismiss the suspicion that Islam approved the system of slavery.

2- Explaining the best way of Islam in dealing with the phenomenon of slavery, and trying to eliminate it.

3- Proving that slaves in Islam found honor and dignity and lived in brotherhood that made them with the free people a single fabric in which no one was distinguished over another.

4- A statement that the human nations have not come up with anything new in dealing with this issue after what Islam presented before.

\section{This study concluded that:}

1- What the enemies of Islam claim that Islam legislated slavery, and helped to maintain its continuity, is an allegation that has no basis in truth, and that it is pure fabrication.

2- What Islam offered to the slaves does not need proof and there is no way to bid for it.

3- Although slavery was considered by many peoples as a legitimate system protected by the laws of the state, Islam developed solutions to eliminate it.

4- What Islam offered solutions to slavery and other similar problems deserves to be recorded in the books of international systems; To follow in the footsteps of legislators and decision makers around the world.

Key words: Slavery, phenomenon, Islam, treatment, liberation, methods.

$$
\text { (منهج الإسلام فى القضاء على الرق...) د. صفية محمد محمد سرحان }
$$

